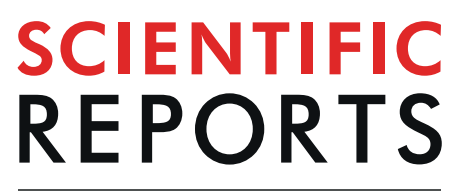

natureresearch

\title{
Integrative systematics and ecology of a new deep-sea family of tanaidacean crustaceans
}

\author{
Magdalena Błażewicz ${ }^{1}$, Piotr Jóźwiak ${ }^{1}$, Robert M. Jennings $\mathbb{D}^{2}{ }^{2}$, Maciej Studzian ${ }^{3}$ \& \\ Inmaculada Frutos $\mathbb{D}^{4,5^{*}}$
}

\begin{abstract}
A new family of paratanaoidean Tanaidacea - Paranarthrurellidae fam. nov. - is erected to accommodate two genera without family classification (Paratanaoidea incertae sedis), namely Armatognathia Kudinova-Pasternak, 1987 and Paranarthrurella Lang, 1971. Seven new species of Paranarthrurella and two of Armatognathia are described from material taken in different deep-sea areas of the Atlantic and Pacific oceans. The type species of Paranarthrurella - P. caudata (KudinovaPasternak, 1965) - is redescribed based on the paratype. The genus Cheliasetosatanais Larsen and Araújo-Silva, 2014 originally classified within Colletteidae is synonymised with Paranarthrurella, and Arthrura shiinoi Kudinova-Pasternak, 1973 is transferred to Armatognathia. Amended diagnoses of Armatognathia and Paranarthrurella genera are given. Choosing characters for distinguishing and defining both genera was supported by Principal Component Analysis. Designation of the new family is supported by molecular phylogenetic analysis of $\mathrm{COI}$ and $18 \mathrm{~S}$ datasets. The distribution of all species currently included in the new family was visualised and their bathymetric distribution analysed.
\end{abstract}

The tanaidacean tanaidomorph genus Paranarthrurella was established by Lang (1971) ${ }^{1}$ to accommodate a conspicuous species described by Kudinova-Pasternak in $1965^{2}$ - Leptognathia caudata Kudinova-Pasternak, 1965. This genus reveals a tangled history. A special 'general appearance' expressed by robust cheliped, rounded (swollen) pleon and peculiar mouthparts was often underlined ${ }^{1-4}$ and although all specialists recognized the morphological distinctiveness of the material studied by them, there was no consensus on its systematic position. In consequence, four currently known nominal species of the genus Paranarthrurella (P. arctophylax (Norman and Stebbing, 1886), P. caudata (Kudinova-Pasternak, 1965), P. dissimilis (Lang, 1972) and P. voeringi (Sars, 1877)), have historically been classified primarily to six distinct genera, namely: Tanais Latreille, $1831^{5,6}$, Cryptocope Sars, $1882^{7,8}$, Leptognathia Hansen, $1913^{1,3,9-11}$, Strongylura (synonymized with Collettea) ${ }^{12}$, Biarticulata (=Leptognathia) ${ }^{13}$, and monotypic Robustognathia (=Paranarthrurella $)^{4}$.

Equally confused was the systematic position of genus Paranarthrurella. Considering the width of the pleonite segments, which are narrower than the last pereonite or pleotelson in the females, Lang classified P. caudata in the Anarthruridae Lang, 1971 disregarding the connection of the cheliped to the body and the character of the exopod in the uropods ${ }^{1}$. Although the morphological uniqueness of Paranarthrurella was later mentioned by $\mathrm{Sieg}^{14}$, the genus was retained within the tribe Anarthurini in Anarthruridae. In the morphological phylogenetic approach of Larsen and Wilson ${ }^{15}$, Paranarthrurella was transferred to Agathotanaidae.

The revision of Paranarthrurella, grounded in revived Paranarthrurella voeringi (=Tanais voeringi (G.O. Sars, 1877)), has confirmed that this genus, with the cheliped attached to the body via a sclerite, cannot be a member of Anarthruridae or Agathotanaidae ${ }^{16}$. It was also emphasised that a unique character of the chelipeds and the mouthparts is distinct among all currently defined families of Tanaidomorpha. Subsequently, Paranarthrurella increased the number of genera of Paratanaoidean family 'incertae sedis'.

Armatognathia, described by Kudinova-Pasternak $(1987)^{17}$ from the Indian Ocean, represents another monotypic genus that remains unclassified to any of the existing tanaidacean families ${ }^{15}$. The type species, A. birsteini

\footnotetext{
${ }^{1}$ University of Lodz, Department of Invertebrate Zoology and Hydrobiology, Laboratory of Polar Biology and Oceanobiology, Banacha St. 12/16, Łódź, 90-237, Poland. ${ }^{2}$ Biology Department, Temple University, Philadelphia, PA, USA. ${ }^{3}$ University of Lodz, Department of Molecular Biophysics, Banacha St. 12/16, tódź, 90-237, Poland. ${ }^{4}$ University of Hamburg, Centre of Natural History, Zoological Museum, Martin-Luther-King-Platz 3, 20146, Hamburg, Germany. ${ }^{5}$ Universidad de Alcalá, Dpto. Ciencias de la Vida, EU-US Marine Biodiversity Group, 28871, Alcalá de Henares, Spain. *email: inmaculada.frutos@biol.uni.lodz.pl
} 
Kudinova-Pasternak, 1987, and the genus were originally placed within the family Leptognathiidae ${ }^{17}$, where it was retained until the phylogenetic analysis of Larsen and Wilson ${ }^{15}$. Kudinova-Pasternak (op. cit.) pointed out that the main character differentiating Armatognathia from the remaining leptognathiid genera was the armament of the mandible molar process. According to the author, Armatognathia shows some affinities with Leptognathia, but differs in the presence of distal spines on the mandibular molar, nine terminal spines on the maxillule palp, and restriction of setation of the pleopods rami to the distal margin.

During examination of the Tanaidacea from various collections made in different deep-sea parts of the Atlantic and the Pacific oceans, we have revealed a series of distinct species, which we classified to two genera: Paranarthrurella and Armatognathia. In this paper we (1) describe all the new species, (2) rediagnose both genera, (3) discuss their relationship, and (4) assign them to a new family Paranarthrurellidae. Moreover, we synonymize the genus Cheliasetosatanais Larsen and Araújo-Silva, $2014^{18}$, considered a member of the family Colletteidae, with Paranarthrurella, and we transfer the one tanaellid species Arthrura shiinoi Kudinova-Pasternak, 1973 to the genus Armatognathia. Similar systematic rearrangement was suggested by Bird and Holdich ${ }^{19}$. Our morphological analyses are supported by molecular phylogenetic analysis of mitochondrial COI and nuclear $18 \mathrm{~S}$ molecular markers. Also, where possible, we use environmental data (as temperature and salinity) to assess distribution of the genus Paranarthrurella in the North Atlantic. Finally, we visualize and analyse the zoogeographic and bathymetric distribution of all species belonging to this new family. An identification key to females of the known twelve species of Paranarthrurella is also provided.

\section{Material}

The specimens used in this study were collected during different scientific initiatives leaded by various research expeditions and teams. The vast majority of specimens used for species descriptions were loaned from Museum of Comparative Zoology (Harvard University) as the result of the series of the campaigns on the in RVs Atlantic II, Knorr and Chain which explored the western Atlantic from the coast of United States (Gay Head-Bermuda transect) through Guiana and Brazilian basins down to the Argentinian coasts between 1966 and $1972^{20}$. Further, a small group of specimens came from the SLOPE project gathered during the Australian program assessing diversity in the Bass Strait (SE Australia ${ }^{21}$ ). All of those collections were first fixed in $4 \%$ buffered formaldehyde and transferred into $75-80 \%$ ethanol for sorting to the highest taxonomical levels.

Recently, more material was collected on board RV Meteor in 2011 during the Icelandic Animals Genetic and Ecology (IceAGE) program in waters of Iceland ${ }^{22}$, and on board RV Sonne, in 2014/2015 on both sides of the Mid-Atlantic Ridge at the Vema Fracture Zone during the Vema-TRANSIT project ${ }^{23}$, and in 2015 from the Central Pacific within the framework of the Joint Programming Initiative Healthy and Productive Seas and Oceans platform (JPI Oceans) ${ }^{24}$. That material was collected, fixed and handled following protocols for fixation as described in Riehl et al. ${ }^{25}$ and was used for molecular analyses. Information about all the expeditions during which the material used for this study was collected is gathered in Table 1.

Additionally, the type species of Paranarthrurella, P. caudata (Kudinova-Pasternak, 1965), borrowed from the Zoological Museum in Moscow, was examined and redescribed ${ }^{2}$. Furthermore, in order to provide a complete description of Paranarthurella arctophylax (Norman and Stebbing, 1886) material collected in the Iceland Basin during BIOICE (Benthic Invertebrates of Icelandic waters) project was also examined and consequentely redescribed. Unfortunately, the other poorly-described historical types - Arthrura shiinoi Kudinova-Pasternak, 1973, Armatognathia birsteini Kudinova-Pasternak, 1987 and Leptognathia dissimilis Lang, 1972 - were inaccessible for our study.

\section{Methods}

Taxonomic analyses. A total of 87 individuals of nine new species was examined morphologically with a Leica M125 stereomicroscope. For all specimens, the body length (BL) was measured from the tip of the rostrum to the distal edge of the pleotelson.

Seven life stages are recognized for the studied individuals: two stages of manca, one neuter, two stages of females, and two stages of males. The terms "manca-2" and "manca-3" refers to specimens without or with buds of pereopod-6, respectively ${ }^{26}$; 'preparatory female' and 'ovigerous female' are bearing oostegites buds either fully developed oostegites, respectively; 'juvenile male' and 'mature male' (swimming) ${ }^{27}$ show incompletely or completely developed sexual dimorphic characters, respectively. Finally, the term 'neuter' is retained for the stage developed from manca-3 that cannot be classified as precopulatory female with oostegites buds (including non-ovigerous females), or juvenile male. Appendages from the chosen specimens were dissected in a glycerine solution using chemically-sharpened tungsten needles, mounted in glycerine on slides, and sealed with paraffin wax. For staining, methylene blue or chlorazol black were used.

Initial drawings were made using a Nikon Eclipse $50 \mathrm{i}$ microscope combined with a camera lucida; they were then digitally inked as proposed by Coleman ${ }^{28}$.

The general morphological terminology follows that proposed by Jóźwiak et al. ${ }^{16}$. The body length-to-width ratio was assessed dividing a measurement of total body length (see above) and by a measurement the widest part of cephalothorax. Length of the articles and segments was measured along the central axis, whereas width was assessed at the mid-length of the article. As proposed by Bird and Bamber ${ }^{29}$, the 'spines' are called the articulated and unflexible cuticular structures while 'setae' are flexible and bristle or hair-like articulated structures; the apophyse (or teeth) are reserved for the nonarticulated cuticular outgrowth. The short, weakly calcified, round tip setae in mandibule molar of Paranarthrurella are called finger-shape setae.

All of the measurements were performed with Leica M205C and LAS V4.5 software. To simplify species descriptions, the expression ' $N x$ ' replaces ' $N$ times as long as' and ' $N \mathrm{~L}: \mathrm{W}$ ' replaces ' $N$ times longer than wide'.

Photographs were made using the focus stacking method on a Leica M205C stereo-microscope combined with a DFC295 camera and LAS V4.5 software. For the redescription of Paranarthrurella arctophylax, confocal 


\begin{tabular}{|c|c|c|c|c|c|c|c|c|c|}
\hline \multirow[b]{2}{*}{ Location } & \multirow[b]{2}{*}{ Date } & \multirow[b]{2}{*}{$\mathbf{R V}$} & \multirow[b]{2}{*}{ Cruise } & \multirow[b]{2}{*}{ Station } & \multicolumn{2}{|l|}{ Position } & \multirow[b]{2}{*}{ Depth (m) } & \multirow[b]{2}{*}{ gear } & \multirow[b]{2}{*}{$\mathrm{N}$} \\
\hline & & & & & longitud & latitude & & & \\
\hline \multicolumn{10}{|l|}{ Atlantic Ocean } \\
\hline Norwegian Basin & $17 / 09 / 2011$ & Meteor & IceAGE1 & 1155 & $69^{\circ} 06.89^{\prime} \mathrm{N}$ & $09^{\circ} 54.72^{\prime} \mathrm{W}$ & $2177-2174$ & EBS & 6 \\
\hline Norwegian Basin & $21 / 09 / 2011$ & Meteor & IceAGE1 & 1191 & $67^{\circ} 04.72^{\prime} \mathrm{N}$ & $13^{\circ} 03.83^{\prime} \mathrm{W}$ & $1577-1578$ & EBS & 2 \\
\hline Porcupine Seabight & $22 / 08 / 1972$ & Chain & 106 & 326 & $50^{\circ} 04.90^{\prime} \mathrm{N}$ & $14^{\circ} 23.80^{\prime} \mathrm{W}$ & 3859 & EBS & 1 \\
\hline Gay Head-Bermuda & $01 / 05 / 1966$ & Chain & 58 & 100 & $33^{\circ} 56.80^{\prime} \mathrm{N}$ & $65^{\circ} 47.00^{\prime} \mathrm{W}$ & $4743-4892$ & EBS & 1 \\
\hline Gay Head-Bermuda & $16 / 08 / 1966$ & Atlantis II & 24 & 115 & $39^{\circ} 39.20^{\prime} \mathrm{N}$ & $70^{\circ} 24.50^{\prime} \mathrm{W}$ & $2030-2051$ & EBS & 2 \\
\hline Gay Head-Bermuda & $20 / 08 / 1966$ & Atlantis II & 24 & 120 & $34^{\circ} 43.00^{\prime} \mathrm{N}$ & $66^{\circ} 32.80^{\prime} \mathrm{W}$ & $5018-5023$ & EBS & 1 \\
\hline Gay Head-Bermuda & $21 / 08 / 1966$ & Atlantis II & 24 & 121 & $35^{\circ} 50.00^{\prime} \mathrm{N}$ & $65^{\circ} 11.00^{\prime} \mathrm{W}$ & 4800 & EBS & 1 \\
\hline Gay Head-Bermuda & $22 / 08 / 1966$ & Atlantis II & 24 & 122 & $35^{\circ} 50.00^{\prime} \mathrm{N}$ & $64^{\circ} 57.50^{\prime} \mathrm{W}$ & 4833 & EBS & 10 \\
\hline Gay Head-Bermuda & $18 / 12 / 1966$ & Atlantis II & 30 & 131 & $39^{\circ} 38.50^{\prime} \mathrm{N}$ & $70^{\circ} 36.50^{\prime} \mathrm{W}$ & 2178 & EBS & 2 \\
\hline Gay Head-Bermuda & $23 / 02 / 1969$ & Chain & 88 & 210 & $34^{\circ} 43.00^{\prime} \mathrm{N}$ & $70^{\circ} 46.00^{\prime} \mathrm{W}$ & 2024-2064 & EBS & 2 \\
\hline Gay Head-Bermuda & $24 / 11 / 1973$ & Knorr & 35 & 340 & $38^{\circ} 14.40^{\prime} \mathrm{N}$ & $70^{\circ} 20.30^{\prime} \mathrm{W}$ & $3264-3356$ & EBS & 5 \\
\hline Vema Fracture-Zone & $02 / 01 / 2015$ & Sonne & Vema-TRANSIT & $6-8$ & $10^{\circ} 22.25^{\prime} \mathrm{N}$ & $36^{\circ} 56.05^{\prime} \mathrm{W}$ & $5137-5127$ & EBS & 1 \\
\hline off Brazil & $14 / 02 / 1967$ & Atlantis II & 31 & 156 & $00^{\circ} 46.00^{\prime} \mathrm{S}$ & $29^{\circ} 24.00^{\prime} \mathrm{W}$ & 3459 & EBS & 19 \\
\hline Argentine Basin & $14 / 03 / 1971$ & Atlantis II & 60 & 245 & $36^{\circ} 55.70^{\prime} \mathrm{S}$ & $53^{\circ} 01.40^{\prime} \mathrm{W}$ & 2707 & EBS & 6 \\
\hline Argentine Basin & $27 / 03 / 1971$ & Atlantis II & 60 & 262 & $36^{\circ} 05.20^{\prime} \mathrm{S}$ & $52^{\circ} 17.90^{\prime} \mathrm{W}$ & $2440-2480$ & EBS & 13 \\
\hline Argentine Basin & $15 / 07 / 2009$ & Meteor & DIVA3 & 533 & $36^{\circ} 00.20^{\prime} \mathrm{S}$ & $49^{\circ} 01.96^{\prime} \mathrm{W}$ & $4601.8-4605.7$ & EBS & 1 \\
\hline \multicolumn{10}{|l|}{ Pacific Ocean } \\
\hline Clarion Clipperton Zone & $01 / 04 / 2015$ & Sonne & JPIO & 81 & $11^{\circ} 03.97^{\prime} \mathrm{N}$ & $119^{\circ} 37.67^{\prime} \mathrm{W}$ & $4401.4-4397.9$ & EBS & 4 \\
\hline Clarion Clipperton Zone & $03 / 04 / 2015$ & Sonne & JPIO & 95 & $11^{\circ} 04.41^{\prime} \mathrm{N}$ & $119^{\circ} 39.35^{\prime} \mathrm{W}$ & 4418.3 & GKG & 2 \\
\hline Clarion Clipperton Zone & $04 / 04 / 2015$ & Sonne & JPIO & 99 & $11^{\circ} 02.28^{\prime} \mathrm{N}$ & $119^{\circ} 40.89^{\prime} \mathrm{W}$ & $4601.8-4605.7$ & EBS & 2 \\
\hline Clarion Clipperton Zone & $05 / 04 / 2015$ & Sonne & JPIO & 106 & $11^{\circ} 04.30^{\prime} \mathrm{N}$ & $119^{\circ} 39.29^{\prime} \mathrm{W}$ & 4425.3 & GKG & 1 \\
\hline Bass Strait & $22 / 07 / 1986$ & Franklin & SLOPE & 25 & $38^{\circ} 25.54^{\prime} \mathrm{S}$ & $148^{\circ} 58.36^{\prime} \mathrm{E}$ & 1850 & EBS & 1 \\
\hline Bass Strait & $15 / 05 / 1994$ & Franklin & SLOPE & 140 & $38^{\circ} 57.44^{\prime} \mathrm{S}$ & $141^{\circ} 37.04^{\prime} \mathrm{E}$ & 1450 & EBS & 1 \\
\hline Bass Strait & $15 / 05 / 1994$ & Franklin & SLOPE & 142 & $38^{\circ} 59.43^{\prime} \mathrm{S}$ & $141^{\circ} 33.18^{\prime} \mathrm{E}$ & 1975 & EBS & 2 \\
\hline Bass Strait & $21 / 05 / 1994$ & Franklin & SLOPE & 170 & $37^{\circ} 05.53^{\prime} \mathrm{S}$ & $137^{\circ} 42.32^{\prime} \mathrm{E}$ & 1548 & MIG & 1 \\
\hline
\end{tabular}

Table 1. Localities and expedition of the stations from where Tanaidacea for the present studies were collected. RV - research vessel, N - number of individuals, EBS - epibenthic sledge; GKG - box corer; MIG - McIntyre grab.

microscopy imaging was used. Images were registered with the confocal laser scanning microscope LSM 780 (Zeiss) equipped with EC Plan-Neofluar 10x/0.30 M27 objective, $405 \mathrm{~nm}$ laser diode and and InTune tunable excitation laser system (set to excitation wavelength $595 \mathrm{~nm}$ ). Natural autofluorescence of the specimen was enhanced by chemical crosslinking by transient incubation in formalin. Otherwise unstained, ethanol-fixed animal was imaged in $100 \%$ glycerol. Autofluorescence was registered sequentially in two emission channels: 410-580 $\mathrm{nm}$ (405 nm excitation) and 600-735 nm (595 nm excitation). In $3 \times 3$ tile scan area $(3188.22 \mu \mathrm{m} \times$ $3188.22 \mu \mathrm{m}$ ), images were collected for stitching along with optimal number of Z-frames, each in $2048 \times 2048$ pixels format with $3.15 \mu$ s pixel dwell and $2 \times$ line averaging. Images in both channels were then combined, pseudo-colored in gold and reconstructed into 2D image stack by maximum intensity projection using ZEN 2012 software (Zeiss).

The type material is deposited in the Museum of Comparative Zoology (MCZ, United States), Zoological Museum of Hamburg (ZMH, Germany) and Melbourne Museum (NMH, Australia). The material for the redescription of Paranarthrurella arctophylax is deposited in the Icelandic Institut of Natural History (NI, Iceland).

DNA extraction, alignment, and phylogenetic analysis. Single appendages (chela or pereopod-1) were taken from each specimen for DNA extraction using sterile needles, and transferred to buffer solution. Extraction of DNA was performed at the Smithsonian Laboratories for Analytical Biology ${ }^{25}$. Two markers were sequenced: the nuclear ribosomal small subunit (18S), and the mitochondrial cytochrome $c$ oxidase subunit I (COI). Polymerase Chain Reactions (PCR) protocols, primer sequences, and sequencing protocols were according to Riehl et al. ${ }^{25}$.

Sequencing reads were assembled in Geneious v. 11.1.4 and checked by hand to resolve ambiguities and remove primer sequences. To place sequences of Paranarthrurella in the proper phylogenetic context, nine sequences of $18 \mathrm{~S}$ and 14 of COI from other genera within superfamily Paratanaoidea were obtained from GenBank (Agathotanaidae, Akanthophoreidae, Cryptocopidae, Paratanaidae, Leptocheliidae, Nototanaidae, Typhlotanaidae; Table $2^{27,30-35}$ ). Finally, a gammarid species for which both COI and $18 \mathrm{~S}$ sequences were accessible in GenBank.

Alignment of $18 \mathrm{~S}$ was performed with the online MAFFT server $\mathrm{v} 7^{36}$, followed by deletion of poorly-aligned regions using the online Gblocks server ${ }^{37}$, employing all three options for less-stringent selection. Alignment of COI was performed on DNA codons using the ClustalX algorithm ${ }^{38}$ in BioEdit (written by Tom Hall, Ibis Theraputics). Both alignments were trimmed to remove large front- and back-end blocks of gaps. Twenty-nine 


\begin{tabular}{|c|c|c|c|c|}
\hline Species & Specimen code & $18 \mathrm{~S}$ & COI & Reference \\
\hline \multicolumn{5}{|l|}{ Agathotanaidae Lang, 1971} \\
\hline Agathotanais ingolfi Hansen, 1913 & ITan029 & & KJ934610 & Błażewicz-Paszkowycz et al..$^{27}$ \\
\hline Agathotanais ingolfi Hansen, 1913 & ITan053 & & KJ934609 & Błażewicz-Paszkowycz et al. ${ }^{27}$ \\
\hline Paranarthrura sp. & & AB618196 & & Kakui et al. ${ }^{31}$ \\
\hline \multicolumn{5}{|l|}{ Akanthophoreidae Sieg, 1986} \\
\hline Akanthophoreus cf. alba & ITan 165 & MK804189 & & this paper \\
\hline Brixia aurora Jóźwiak, Drumm, Bird \& Błażewicz, 2018 & ITan028 & MK804190 & KJ934607 & this paper; Jóźwiak et al. ${ }^{30}$ \\
\hline Brixia aurora Jóźwiak, Drumm, Bird \& Błażewicz, 2018 & ITan117 & & KJ934608 & Jóźwiak et al..$^{30}$ \\
\hline Chauliopleona armata (Hansen, 1913) & ITan059 & MK804188 & & this paper \\
\hline Chauliopleona sp. & & AB618200 & & Kakui et al..$^{31}$ \\
\hline \multicolumn{5}{|l|}{ Colletteidae Larsen and Wilson, 2002} \\
\hline Collettea aff. wilsoni & ITan017 & MK804191 & & this paper \\
\hline Collettea sp. & ITan057 & MK804192 & & this paper \\
\hline \multicolumn{5}{|l|}{ Cryptocopoidae Sieg, 1977} \\
\hline Cryptocopoides aff. arcticus & ITan092 & & KJ934611 & Błażewicz-Paszkowycz et al..$^{27}$ \\
\hline Cryptocopoides aff. arcticus & ITan122 & & KJ934612 & Błażewicz-Paszkowycz et al. ${ }^{27}$ \\
\hline \multicolumn{5}{|l|}{ Leptocheliidae Lang, 1973} \\
\hline Chondrochelia dubia (Krøyer, 1842) & & & HM016215 & Drumm 2010 \\
\hline Chondrochelia dubia (Krøyer, 1842) & & & JX402115 & Larsen et al. ${ }^{34}$ \\
\hline Leptochelia forresti Stebbing, 1896 & & & HM016206 & Drumm 2010 \\
\hline Leptochelia forresti Stebbing, 1897 & & & KP255266 & Leray and Knowlton ${ }^{33}$ \\
\hline Leptochelia longichelipes (Lang, 1973) & & & HM016201 & Drumm 2010 \\
\hline Makassaritanais itoi (Ishimaru, 1985) (=Leptochelia itoi) & & AB618197 & & Kakui et al..$^{31}$ \\
\hline Leptochelia sp. & & AF496660 & & Wägele et al. unpublished 2004 \\
\hline \multicolumn{5}{|l|}{ Paranarthrurellidae fam. nov. } \\
\hline Paranarthrurella polonez sp. nov. & ind 171 & MK804182 & & this paper \\
\hline Paranarthrurella polonez sp. nov. & ind 182 & MK804183 & & this paper \\
\hline Paranarthrurella sp.1 & ITan159 & & MK751353 & this paper \\
\hline Paranarthrurella sp. 1 & ITan163 & & MK751356 & this paper \\
\hline Paranarthrurella sp.1 & ITan164 & & MK751357 & this paper \\
\hline Paranarthrurella sp. 2 & ITan158 & MK804177 & MK751352 & this paper \\
\hline Paranarthrurella sp. 2 & ITan160 & MK804178 & MK751354 & this paper \\
\hline Paranarthrurella sp. 2 & ITan162 & MK804179 & & this paper \\
\hline Paranarthrurella sp. 2 & ITan161 & & MK751355 & this paper \\
\hline Paranarthrurella sp.2 & ITan170 & & MK751358 & this paper \\
\hline \multicolumn{5}{|l|}{ Paratanaidae Lang, 1949} \\
\hline Metatanais sp. & & AB618201 & & Kakui et al..$^{31}$ \\
\hline Aparatanais malignus (Larsen, 2001) (=Paratanais malignus) & & AY781429 & & Larsen $^{32}$ \\
\hline Paratanais sp. & & AB618199 & & Kakui et al..$^{31}$ \\
\hline \multicolumn{5}{|l|}{ Nototanaidae Sieg, 1976} \\
\hline Nesotanais ryukyuensis Kakui, Kajihara \& Mawatari, 2010 & & AB618198 & & Kakui et al..$^{31}$ \\
\hline \multicolumn{5}{|l|}{ Tanaellidae Larsen and Wilson, 2002} \\
\hline Tanaella ochracea Hansen, 1913 & ITan027 & MK804194 & & this paper \\
\hline Tanaella unguicillata Norman \& Stebbing, 1886 & ITan015 & MK804193 & & this paper \\
\hline Tanaella unguicillata Norman \& Stebbing, 1886 & ITan043 & MK804195 & & this paper \\
\hline Tanaella unguicillata Norman \& Stebbing, 1886 & ITan135 & MK804196 & & this paper \\
\hline \multicolumn{5}{|l|}{ Typhlotanaidae Sieg, 1984} \\
\hline Typhlotanais cornutus (G.O. Sars, 1879) & ITan040 & & MK751359 & this paper \\
\hline Typhlotanais cornutus (G.O. Sars, 1879) & ITan041 & & MK751360 & this paper \\
\hline Typhlotanais eximus Hansen, 1913 & ITan076 & & MK751361 & this paper \\
\hline Typhlotanais eximus Hansen, 1913 & ITan128 & & MK751362 & this paper \\
\hline Typhlotanais mixtus Hansen, 1913 & ITan021 & MK804185 & & this paper \\
\hline Typhlotanais trispinosus Hansen, 1913 & ITan014 & MK804184 & & this paper \\
\hline Typhlotanais variabilis Hansen, 1913 & ITan050 & & KJ934599 & Błażewicz-Paszkowycz et al.$^{27}$ \\
\hline Typhlotanais variabilis Hansen, 1913 & ITan068 & MK804186 & KJ934602 & this paper; Błażewicz-Paszkowycz et al. ${ }^{27}$ \\
\hline Typhlotanais variabilis Hansen, 1913 & ITan069 & MK804187 & KJ934600 & this paper; Błażewicz-Paszkowycz et al. ${ }^{27}$ \\
\hline
\end{tabular}

Table 2. Details on the tanaidacean taxa used for genetic analysis applying COI and 18S markers. 
new sequences obtained for this project were deposited in GenBank (Accessions MK751352- MK751362 and MK804177-MK804196, Table 2). Pairwise distances within Paranarthrurella, within non-Paranarthrurella, and between the two groups were calculated in MEGA $5^{39}$ using the K2P distance model $^{40}$.

Bayesian phylogenetic trees were computed in BEAST 2.5.0 $0^{41}$ using a four-category gamma-distributed model of sequence mutation for both markers. For COI, the HKY mutational model was employed, whereas for $18 \mathrm{~S}$ the GTR model was used. Strict clocks and Yule tree priors were used for both markers. All gamma priors for GTR rates were replaced with default lognormal priors. Convergence of the runs was assessed with Tracer v1.6 $6^{41}$ to choose a burn-in such that all effective sample sizes (ESSs) were at least 200. Consensus trees were produced and annotated with Bayesian posterior probabilities (PP) using TreeAnnotator in the BEAST2 package. Because there were few ingroup specimens for which both $18 \mathrm{~S}$ and COI were obtained (five), no multilocus tree was estimated.

Species delimitation. Species delimitation was performed on COI sequences of Paranarthrurella using three methods: the ABGD algorithm (Automated Barcode Gap Discovery) ${ }^{42}$, GMYC method (General Mixed Yule Coalescent) ${ }^{43}$, and mPTP algorithm (Multiple Threshold PTP $)^{44}$. Because species delimitation (SD) analyses can be sensitive to the taxonomic depth of the tree, a pruned dataset was used, including only Paranarthrurella and Cryptocope sequences. The ABGD method required the alignment as input, and was performed using the online version (snv.jussieu.fr/public/abgd/abgdweb.html) on Kimura 2-parameter (K2P) ${ }^{45}$ corrected pairwise distances and 20 algorithm steps. The GMYC and mPTP analyses required the ultrametric tree produced by BEAST; GMYC analysis was conducted in $\mathrm{R}$ with the single-threshold option, and mPTP was performed using the command-line software, employing 20,000 burn-in steps and three replicate runs.

Nomenclatural acts. The electronic edition of this article conforms to the requirements of the amended International Code of Zoological Nomenclature, and hence the new names contained herein are available under that Code from the electronic edition of this article. This published work and the nomenclatural acts it contains have been registered in ZooBank, the online registration system for the ICZN. The ZooBank LSIDs (Life Science Identifiers) can be resolved and the associated information viewed through any standard web browser by appending the LSID to the prefix "http://zoobank.org/". The LSID for this publication is: urn:lsid:zoobank. org:pub: E6E09F88-9F8B-4FB9-9FAB-078CFB893D40. The electronic edition of this work was published in a journal with an ISSN, and has been archived and is available from the following digital repositories: PubMed Central and LOCKSS.

Principal component analysis. To quantify the characters used for distinguishing the genus Paranarthrurella from Armatognathia, a Principal Component Analysis (PCA) was conducted on 13 morphological features for the 16 currently known species of the new family herein described (Table 3 ). The analysis was run on normalized data using PRIMER 5 software ${ }^{46}$

Morphological characters:

1. Body length $(\mathrm{BL})$ : short (length/width ratio $<6$ ); long (length /width ratio $>8$ ).

2. Hyposphaenium (H2) of pleonite-2: absent; small; well developed.

3. Hyposphaenium (H3) of pleonite-3: absent; small; well developed.

4. Hyposphaenium (H4) of pleonite-4: absent; small.

5. Antenna (A2) article-2 ornamentation: spine; seta.

6. Mandible $(\mathrm{Mdb})$ molar ornamentation: finger-shape (tip rounded) setae; robust spines.

7. Maxilliped endite gustatory cusps (Mxp gc): slender; round (tubercles).

8. Chela (Ch): slender $(>1.6 \mathrm{~L}: \mathrm{W})$; robust $(<1.3 \mathrm{~L}: \mathrm{W})$.

9. Cheliped (Chp) carpus length/width.

10. Cheliped basis (Chp b) distal part: long (dorsal concave in midlength); short (dorsal concave in distal half);

11. Pleopods $(\mathrm{Pl})$ in female: present; absent.

12. Uropod (U) endopod article-2/article-1 ratio: subequal; longer.

13. Uropod (U) exopod/endopod length.

\section{Results}

Morphological analysis of 87 individuals provisionally classified to Paranarthrurella allowed the observation of a series of morphological features (e.g.: left mandible lacinia mobilis broad, widely separated from incisor forming "spoon-like" gap, rounded and swollen pleon) which are also present in a few other species known from the literature, such as Armatognathia birsteini Kudinova-Pasternak, 1987 and the tanaellid Arthrura shiinoi Kudinova-Pasternak, 1973, and the colletteid recently described Cheliasetosatanais spinimaxillipedus Larsen \& Araújo-Silva, 2014. The morphological analysis of those synapomorphies allowed us to propose to erect a new family - Paranarthrurellidae fam. nov. - which include the three aforementioned species as well. The morphological analysis was supported by genetic results (see below). The investigation of the material has revealed the presence of seven new species which represent the genus Paranarthrurella and two which represent the genus Armatognathia.

Genetics. From the 16 individuals of genus Paranarthrurella that were preserved for molecular analysis, we were able to successfully amplify six sequences for $18 \mathrm{~S}$ and seven sequences for COI. The PCR success was rather low (38\% and 44\%) which is rather typical for small and poorly-investigated deep-sea organisms (Table 3). Pairwise K2P distances for COI within the proposed Paranarthrurellidae fam. nov. were much smaller than those between members of this family and other tanaids, although genetic diversity was low in the group 


\begin{tabular}{|c|c|c|c|c|c|c|c|c|c|c|c|c|c|c|}
\hline Character species & BL & H2 & H3 & H4 & A2 & Mdb & Mxp gc & Ch & Chp & Chp b & Pl 우 & $\begin{array}{l}\mathrm{U} \text { end } \\
\text { article } 1 / 2\end{array}$ & $\begin{array}{l}\text { U end/ } \\
\text { exo }\end{array}$ & Source \\
\hline A. birsteini & long & absent & absent & absent & spine & spines & tubercles? & robust & 1.1 & long & present & longer & 1.6 & $\begin{array}{l}\text { Kudinova- } \\
\text { Pasternak }^{17}\end{array}$ \\
\hline A. milonga sp. nov. & long & absent & absent & absent & spine? & spines & tubercles & robust & 1.0 & long & present & longer & - & current study \\
\hline A. shiinoi & long & - & - & - & spine? & spines? & tubercles? & robust & 1.4 & long & present & longer & 1.7 & $\begin{array}{l}\text { Kudinova- } \\
\text { Pasternak }^{86}\end{array}$ \\
\hline A. swing sp. nov. & long & absent & absent & absent & spine & spines & tubercles & robust & 1.0 & long & present & longer & 1.8 & current study \\
\hline P. arctophylax & short & absent & $\begin{array}{l}\text { well } \\
\text { developed }\end{array}$ & absent & seta & palpate setae? & long? & slender & 1.3 & short & absent & subequal & - & $\begin{array}{l}\text { Norman and } \\
\text { Stebbing } 1886\end{array}$ \\
\hline P. caudata & long & absent & absent & absent & seta & palpate setae & long & slender & 1.6 & short & absent & subequal & 1.5 & $\begin{array}{l}\text { Kudinova- } \\
\text { Pasternak }^{2} \text {, } \\
\text { current study }\end{array}$ \\
\hline P. corroboree sp. nov. & short & small & $\begin{array}{l}\text { well } \\
\text { developed }\end{array}$ & absent & seta & palpate setae & palpate setae & slender & 1.4 & short & absent & subequal & 1.5 & current study \\
\hline P. dissimilis & long & absent & absent & absent & seta & palpate setae & long & slender & 1.4 & short & absent & subequal & 1.3 & Lang $^{9}$ \\
\hline P. kizomba sp. nov. & long & absent & absent & absent & seta & palpate setae & palpate setae & slender & 1.3 & short & absent & subequal & 1.6 & current study \\
\hline P. moonwalk sp. nov. & short & small & $\begin{array}{l}\text { well } \\
\text { developed }\end{array}$ & absent & seta & palpate setae & palpate setae & slender & 1.1 & short & absent & subequal & 1.6 & current study \\
\hline P. polonez sp. nov. & long & absent & absent & absent & seta & palpate setae & palpate setae & slender & 1.6 & short & absent & subequal & 1.1 & current study \\
\hline P. rocknroll sp. nov. & short & absent & small & absent & seta & palpate setae & palpate setae & slender & 1.3 & short & absent & subequal & - & current study \\
\hline P. samba sp. nov. & long & absent & absent & absent & seta & palpate setae & palpate setae & slender & 1.6 & short & absent & subequal & 1.4 & current study \\
\hline P. spinimaxillipeda & long & absent & absent & absent & seta & palpate setae? & - & slender & 1.4 & short & absent & subequal & 1.4 & $\begin{array}{l}\text { Larsen and } \\
\text { Araújo-Silva }^{18}\end{array}$ \\
\hline P. tango sp. nov. & short & absent & small & absent & seta & palpate setae & palpate setae & slender & 1.2 & short & absent & subequal & 1.2 & current study \\
\hline P. voeringi & short & $\begin{array}{l}\text { well } \\
\text { developed }\end{array}$ & $\begin{array}{l}\text { well } \\
\text { developed }\end{array}$ & small & seta & palpate setae & palpate setae & slender & 1.4 & short & absent & subequal & 1.5 & $\begin{array}{l}\text { Jóźwiak et al. } .^{16} \text {, } \\
\text { current study }\end{array}$ \\
\hline
\end{tabular}

Table 3. Morphological characters used to define the genera Paranarthrurella and Armatognathia by means of Principal Component Analysis (PCA): BL, body length; H, hyposphaenium; A2, antenna; Mdb, mandible; Mxp gc, maxilliped endite gustatory cusps; $\mathrm{Ch}$, chela; Chp, cheliped; Chp b, Cheliped basis distal part; Pl, pleopods; $\mathrm{U}$, uropod; end, endopod; exo, exopod; —: data not available.

due to the small sampling of taxa (Table 4). Nevertheless, phylogenetic analysis recovered a monophyletic Paranarthrurellidae with maximum support in both loci (Figs 1 and 2). The GMYC analysis of Paranarthrurella COI sequences $(n=7)$ delimited two species, one corresponding to Paranarthrurella sp. 1 and the other to Paranarthrurella sp. 2; ABGD and mPTP analyses delimited all sequences to a single species (Fig. 1). Both the GMYC and mPTP analyses grouped 18S sequences of Paranarthrurella into two species corresponding to $P$. polonez sp. nov. and Paranarthrurella sp.2; ABGD analysis delimited all $18 \mathrm{~S}$ sequences to a single species (Fig. 2).

Principal component analysis. PCA divides the taxa onto three groups (Fig. 3). The first, second and third axes explain $52.7 \%, 15.3 \%$ and $8.4 \%$ of total variation, respectively. Axes 4 and 5 (not illustrated on Fig. 3) explain together only $11.4 \%$ of a variation. At first glance, two groups of features clearly differentiate the two genera, Armatognathia and Paranarthrurella, along axis 1. The genus Armatognathia is characterised by: presence of spine on antennular article-2, presence of spines on the mandible molar, rounded gustatory cusps (tubercles) on the maxilliped endites, robust chela, cheliped distal part long, presence of pleopods in females, and article-1 of the uropod endopod longer than article-2. The genus Paranarthrurella is characterised by: presence of a seta on antennulal article-2, finger-shape setae on the mandible molar, slender gustatory cusps (spine-like) on the maxilliped endites, slender chela, cheliped distal part short, absence of pleopods in females, and subequal articles 1 and 2 of the uropod endopod.

Axes 2 and 3 cluster Paranarthrurella into two species groups. The first group, which includes $P$. spinimaxillipeda, $P$. samba sp. nov., $P$. polonez sp. nov., P. tango sp. nov., $P$. kizomba sp. nov., $P$. caudata and $P$. dissimilis, has a longer body (except $P$. tango sp. nov.), uropod endopod/exopod length ratio lower and absence of hyposphaenium on pleonites 2 and 3. Additionally, P. polonez sp. nov. and P. samba sp. nov. have an elongated cheliped carpus. In the second group, $P$. rocknroll sp. nov., $P$. arctophylax, $P$. corroboree sp. nov. and $P$. moonwalk sp. nov. have short bodies, presence of hyposphaenium on pleonites 2 and 3 (only in $P$. rocknroll the hyposphaenium on pleonite 2 is absent), uropod endopod/exopod length ratio higher and the cheliped carpus L/W ratio is smaller. Paranarthrurella voeringi is an outlier in the distinct presence of small hyposphaenium in pleonite 4 and large hyposphaenium on 3. Additionally, features localised on pereopods as follows: pereopod 4-6 propodus spine, pereopod-1 merus/carpus spines were correlated with PC Axes 4 and 5, are not illustrated on Fig. 3. They do not play a significant role in morphological differentiation of the two genera, but are important for discrimination of particular species.

Systematics and Taxonomy

Suborder Tanaidomorpha Sieg, 1980

Superfamily Paratanaoidea Lang, 1949 


\begin{tabular}{|l|l|l|l|}
\hline \multicolumn{2}{|l|}{} & COI & 18 S \\
\hline \multicolumn{2}{|l|}{ within P } & 0 & 0 \\
\hline & min & 0.05816 & 0.022 \\
\hline & max & 0.0280 & 0.01256 \\
\hline & mean & 0 & 0.0089 \\
\hline \multicolumn{4}{|l|}{ within NP } \\
\hline \multicolumn{2}{|l|}{ min } & 0.73081 & 0.3111 \\
\hline & max & 0.4629 & 0.1333 \\
\hline & mean & 0.39796 & 0.04065 \\
\hline \multicolumn{2}{|l|}{ between P and NP } & 0.68622 & 0.35183 \\
\hline & min & 0.5289 & 0.10706 \\
\hline & max &
\end{tabular}

Table 4. Genetic distance based on COI and $18 \mathrm{~S}$ markers between Paranarthrurella (P) and nonParanarthrurella (NP) taxa, and between both groups.

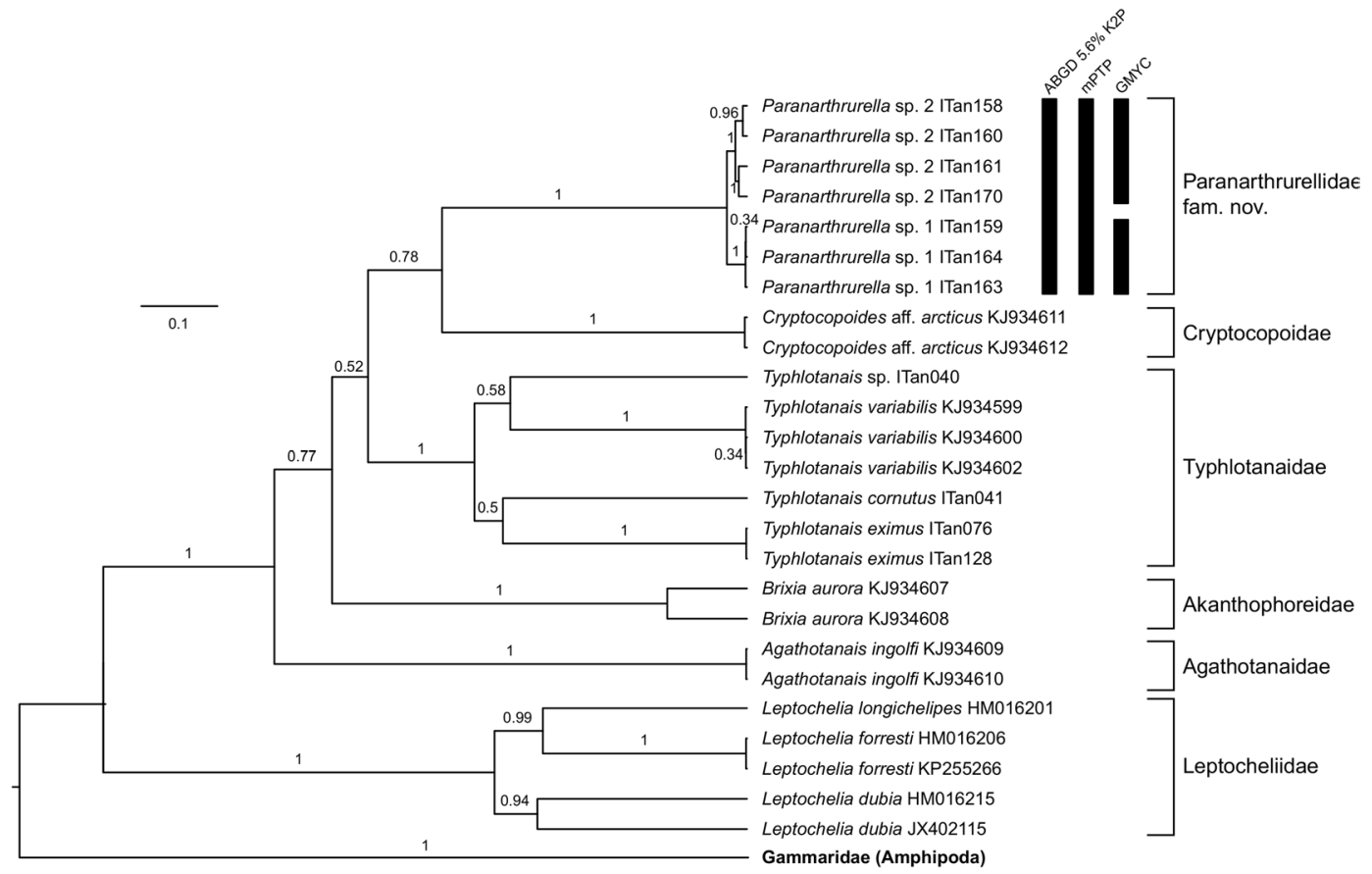

Figure 1. Species delimitation on the COI data using the ABGD algorithm (automatic barcode gap discovery), GMYC (general mixed Yule coalescent), and mPTP (multiple threshold PTP).

Family Paranarthrurellidae fam. nov. Błażewicz, Jóźwiak and Frutos urn:Isid:zoobank.org:act:F9179CD9-B880-4A25-BE83-33CF8F5F5E02

Diagnosis. Body strongly calcified with six well developed pereonites and five distinct pleonites; eyes absent; antennule with four articles, with additional cap-like article; antennae with six articles; mandible molar wide, rounded with row of blunt distal spines; mandible left lacinia mobilis broad, widely separated from incisor forming "spoon-like" gap; maxillule endite with distal spines and numerous setae along outer margin; maxilliped basis fused, endites separated, with two round and well-developed (tubercle) or slender spine-like (gustatory cusps); cheliped attached to cephalothorax with sclerite; sclerite large, triangular (proximal margin little shorter than sclerite main axis); pereopods 1-3 with coxa, merus and carpus with usually small and fine spines; pereopods 4-6 carpus with four spines; pereopod-6 propodus with three distodorsal spines; uropods shorter than pleotelson, biramous, each rami with two articles.

Males: Pleotelson with terminal elongated apophysis; antennule with seven articles (three peduncular and four flagellar); mouthparts reduced; maxilliped present; pleopods well developed; uropod endopod with three articles, exopod with three articles.

Type genus: Paranarthrurella Lang, 1971

Genera included: Armatognathia Kudinova-Pasternak, 1987; Paranarthrurella Lang, 1971 


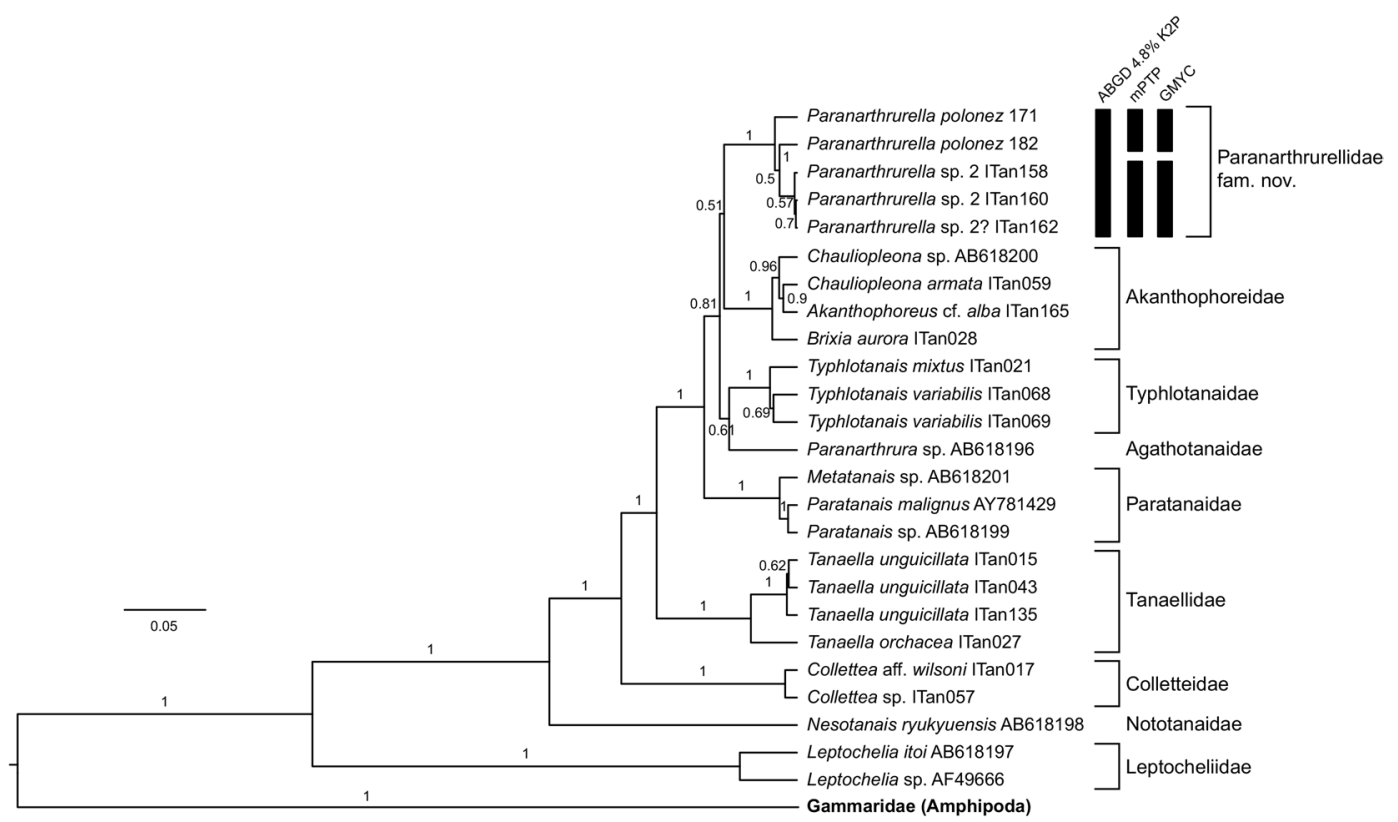

Figure 2. The maximum-parsimony trees based on $18 \mathrm{~S}$ rRNA gene sequence data demonstrating monophyly of six families e.g. Akanthophoreidae Sieg, 1986, Typhlotanaidae Sieg, 1984, Agathotanaidae Lang, 1971, Paratanaidae Lang, 1949, Nototanaidae Sieg, 1976 and Leptocheliidae Lang, 1973, and two genera: Tanaella Norman and Stebbing, 1886 and Collettea Lang, 1973.

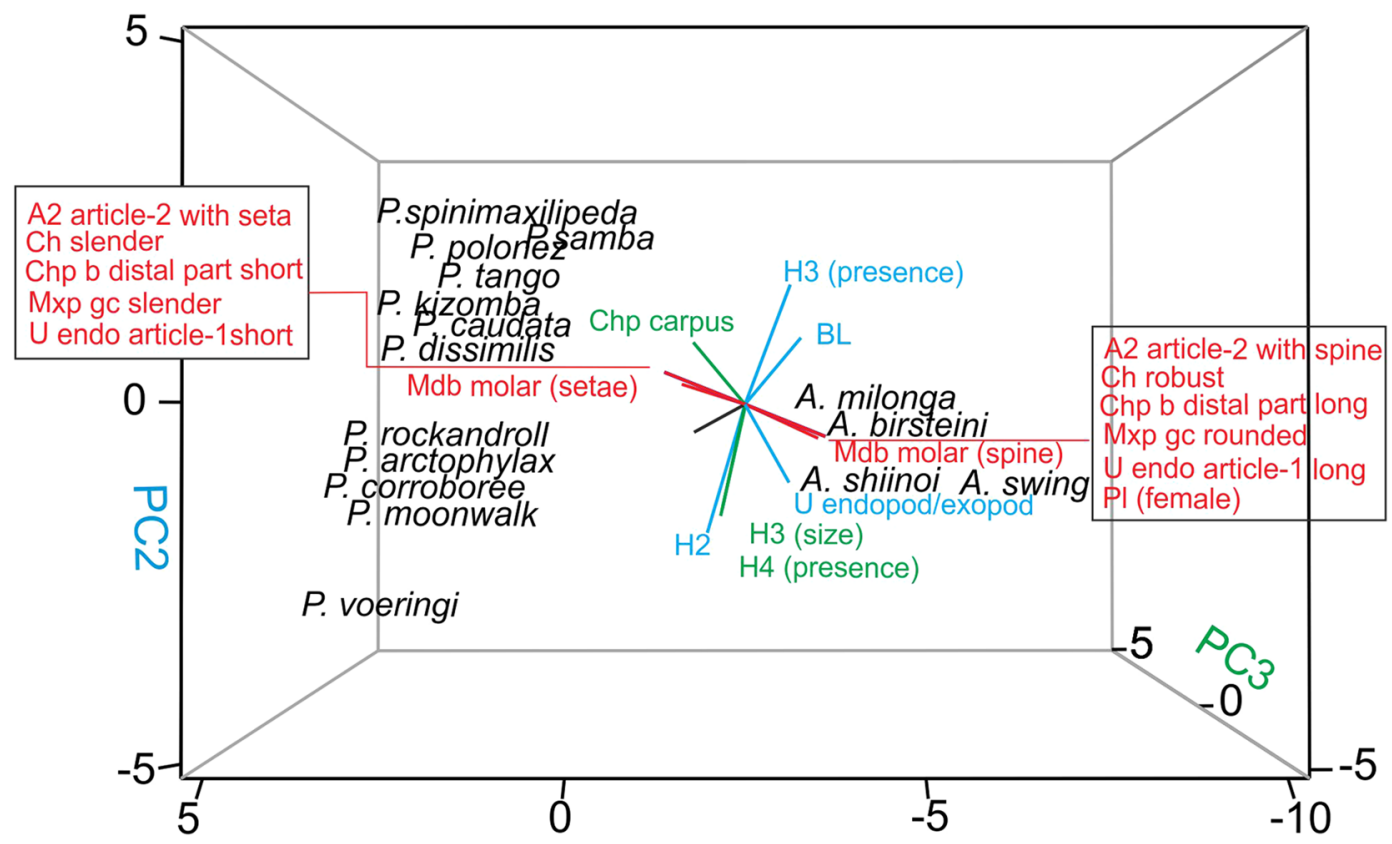

Figure 3. Principal Components Analysis plot (PCA) of twelve Paranarthrurella species and four Armatognathia species and thirteen characters listed in the Table 3.

Remarks. The current systematics of the superfamily Paratanaoidea rely on the number of articles in the antennule (three or four, regardless that some families retain a fifth vestigial article ${ }^{47}$ ), character of the uropod exopod, and a character of the cheliped attachment to cephalothorax ${ }^{15,48}$. From this perspective the new family is readily distinguished from:

- Heterotanaoididae Bird, $2012^{49}$. Leptocheliidae Lang, $1973^{50}$, Nototanaidae Sieg, $1976^{51}$ Pseudotanaidae Sieg, $1976^{51}$, Pseudozeuxidae Sieg, $1982^{52}$, Tanaissuidae Bird and Larsen, $2009^{48}$, and Typhlotanaidae Sieg, $1984^{53}$ which have three, well developed articles on the antennule - by presence of four well developed articles in antennule; 
- Agathotanaidae Lang, $1971^{1}$ and Anarthruridae Lang, $1971^{1}$, which have pseudocoxa - by having cheliped attached to cephalothorax by sclerite (= cheliped basis with a free posterior lobe).

- Tanaellidae Larsen and Wilson, $2002^{15}$, which missing or fused exopod in uropods - by having well developed both exopod and endopod in uropods;

- Mirandotanaidae Błażewicz-Paszkowycz and Bamber, $2009^{54}$ which have enlarged pleotelson ${ }^{54}$ - by having regularly developed pleotelson;

- Teleotanaidae Bamber, $2008^{55}$ and Paratanaidae Lang, $1949^{56}$ - by absence of the eyes and absence of the robust lateral seta on pleonites 1-4; additionally shallow-water Teleotanaidae have dark pigmentation of tegument that never occurs in deep-water Paranarthrurellidae;

- Cryptocopidae Sieg, $1977^{57}$, by shape of the sclerite that connect cheliped to tegument. It is very narrow and almost parallel to ventroproximal corner of the carapace ${ }^{58}$, while it is wide and triangular in Paranarthrurellidae fam. nov.;

- Tanaopsidae Błażewicz-Paszkowycz and Bamber, $2012^{59}$ - by absence of the crenulation on cheliped dactylus and coxal spur on pereopod-1;

- Akanthophoreidae Sieg, $1986^{14}$ - by presence of relatively short and robust uropods. In contrast to Paranarthrurellidae, Akanthophoreidae uropods are always slender and elongated. Yet, Akanthophoreidae have often robust and prominent spines on merus and carpus of the pereopods 1-3, while Paranarthrurellidae fam. nov. have usually slender and relatively short spines in those appendages.

From the list of 18 families, two of them, namely Colletteidae Larsen and Wilson, 2002 and Leptognathiidae Sieg, 1976 are obviously polyphyletic and/or repository taxa with biramous uropods, antennule with four articles, with broad (Colletteidae) or pointed (Leptognathiidae) mandible molar; certainly, both families require severe revision. Until such analysis can be done, the new family can still be distinguished from those two families by characteristic mouthpart details (wide mandible molar with row of blunt distal spines; left lacinia mobilis broad and widely separated from incisor forming "spoon-like" gap; maxillule endite numerous setae along outer margin; maxilliped endites separated, with two well-developed or slender gustatory cusps and peculiar, rounded pleotelson).

\section{Genus Paranarthrurella Lang, 1971.}

Tanais Latreille, $1831^{5}$ (partim.): G.O. Sars, 1877: 347, 3706; G.O. Sars, 1882: 507; G.O. Sars, 1896: 33; Sieg, 1980: $11-12^{60}$.

Cryptocope G.O. Sars, $1882^{7}$ (partim.): G.O. Sars, 1882: 50-517 ; G.O. Sars, $1885: 74-78^{61}$; Forsstrand, 1886: 4762; Norman, 1899: 34063; Zirwas, 1911: 105 ${ }^{64}$; Hansen, 1913: 106, 109-110, pl X' ${ }^{8}$ Nierstrasz, 1913: 33 ${ }^{65}$; Lang, 1949: 6, $8^{56}$; Stephensen, 1932: $349^{66}$; Lang, 1971: $403^{1}$.

Leptognathia G.O. Sars, 1882 (partim.) $^{7}$ : Kudinova-Pasternak, 1965: 75, 88-91²; Belyaev, 1966: 88 ${ }^{67}$; Kudinova-Pasternak, 1968: 73 ${ }^{68}$; Lang, 1968: 160-161 ${ }^{69}$; Lang, 1971: 361-362 $2^{70}$; Gardiner, 1975: 225 $5^{71}$; Lang, 1972:

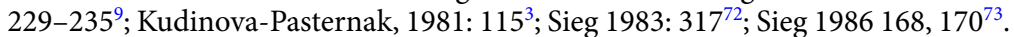

Strongylura G.O. Sars, 1882 (partim.): Norman and Stebbing, 1886: 110, $133^{12}$.

Paranarthrurella Lang, 1971: 361, 363, 367 ${ }^{70}$; Sieg, 1973: 34-281 ${ }^{74}$; Sieg, 1976: 178 $8^{51}$; Sieg, 1978: $121^{75}$.

Robustognathia Kudinova-Pasternak, 1989: 68, 33-344.

Biarticulata Larsen and Shimomura, 2007 (partim) ${ }^{13}:$ 19; Bird, 2007: 7576.

Cheliasetosatanais Larsen and Araújo-Silva, 2014: 969-972 ${ }^{18}$; Larsen, Gutu and Sieg 2015: 257, 260, 304, Fig. 59.377; Wi, Suh and Kim, 2015: 725 $5^{78}$; Morales-Nuñez, Larsen and Cooke, 2016: 11, Tab ${ }^{79}$.

Type species: Paranarthrurella caudata (Kudinova-Pasternak, 1965)

Species included: Paranarthrurella arctophylax (Norman and Stebbing, 1886), P. caudata (Kudinova-Pasternak, 1965), P. corroboree sp. nov., P. dissimilis (Lang, 1972), P. kizomba sp. nov., P. moonwalk sp. nov., P. polonez sp. nov.; P. rocknroll sp. nov.; P. samba sp. nov.; P. spinimaxillipeda (Larsen and Araújo-Silva, 2014), $P$. tango sp. nov., $P$. voeringi (Sars, 1877).

Diagnosis. Female: Body long or short (five to ten L:W). Pereonites subrectangular or subsquare; pereonites 1-3 usually slightly wider anteriorly; pereonite-6 slightly wider posteriorly. Antenna article-2 with seta distally. Molar with short (finger-shape) spines. Maxilliped endites with slender gustatory cusps. Cheliped carpus slender (usually >1.6 L:W). Cheliped basis distal part short (dorsal concave in distal half). Chela slender. Pleopods absent in females. Uropod endopod article-1 subequal article-2.

\section{Paranarthrurella caudata (Kudinova-Pasternak, 1965)}

Figures $4-6$

Material examined. Holotype, neuter $3.0 \mathrm{~mm} \mathrm{BL}$ (Mc 938), RV Vityaz, St. 3663, $6^{\circ} 13.4^{\prime} \mathrm{S}, 153^{\circ} 43.7^{\prime} \mathrm{E}, 7^{7} 7_{4}-$ 8006 m, (coll. Birstein in 1957).

Diagnosis. Female: Body long (>8 L:W). Pereonite-1 0.7 L:W. Pleonites lateral margin smooth. Pleonites without hyposphaenium. Pleotelson subrectangular, apex large. Cheliped carpus 1.6 L:W. Pereopod-1 merus with one spine. Pereopods 4-6 carpus with three spines. Pereopods 4-5 propodus dorsodistal spine strongly serrate. Pereopod-6 propodus dorsodistal spines weakly serrated. Uropod endopod 1.5x exopod.

Description of neuter, length $3.0 \mathrm{~mm}$. Body (Fig. 4A,B) elongate, 9.0 L:W; cephalothorax 1.5 L:W, 2.1x pereonite-1. Pereonites $1-6: 0.7,0.8,0.9,1.1,1.1$ and $0.7 \mathrm{~L}: \mathrm{W}$, respectively. Pereonites $2-5$ about as long as wide, pereonites 1-3 wider proximally, pereonites $4-5$ wider in midlength. Pleon 0.2 of total body length. All pleonites the same size, 0.3 times L:W. Pleotelson as long as four pleonites together, subrectangular in the dorsal view, apex large, pointed, directed backward. 

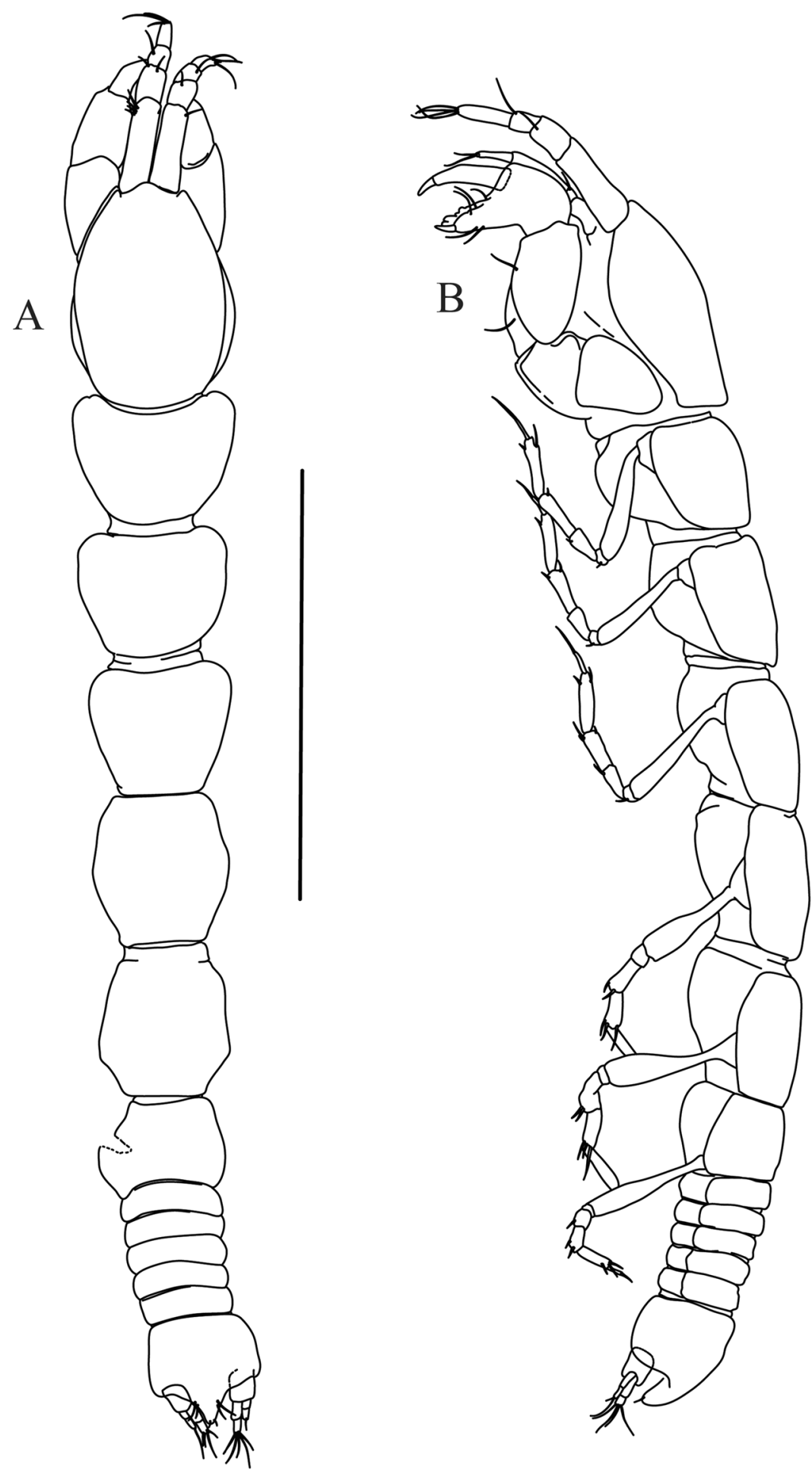

Figure 4. Paranarthrurella caudata (Kudinova-Pasternak, 1965), holotype, female (Mc-938). (A) Dorsal. (B) Lateral. Scale $1 \mathrm{~mm}$.

Antennule (Fig. 5A) article-1 3.0 L:W, 2.3x article-2, no setae observed; article-2 1.5 L:W, 1.4x article-3, with one simple and one penicillate setae distally; article-3 1.4 L:W, 0.6x article-4, with one simple and two penicillate setae distally; article-4 3.3 L:W; article-5 vestigial, partly fused with article-4, with five simple and one penicillate setae, and aesthetasc distally.

Antenna (Fig. 5B) article-1 fused with body; article-2 1.8 L:W, 1.4x article-3, with distodorsal seta; article-3 1.1 L:W, $0.3 \mathrm{x}$ article-4, with distodorsal seta; article- $44.1 \mathrm{~L}: \mathrm{W}, 1.8 \mathrm{x}$ article-5, with one simple and four penicillate setae distally; article-5 4.7 L:W, with distal seta; article-6 as long as wide, with four long and one short distal setae. 


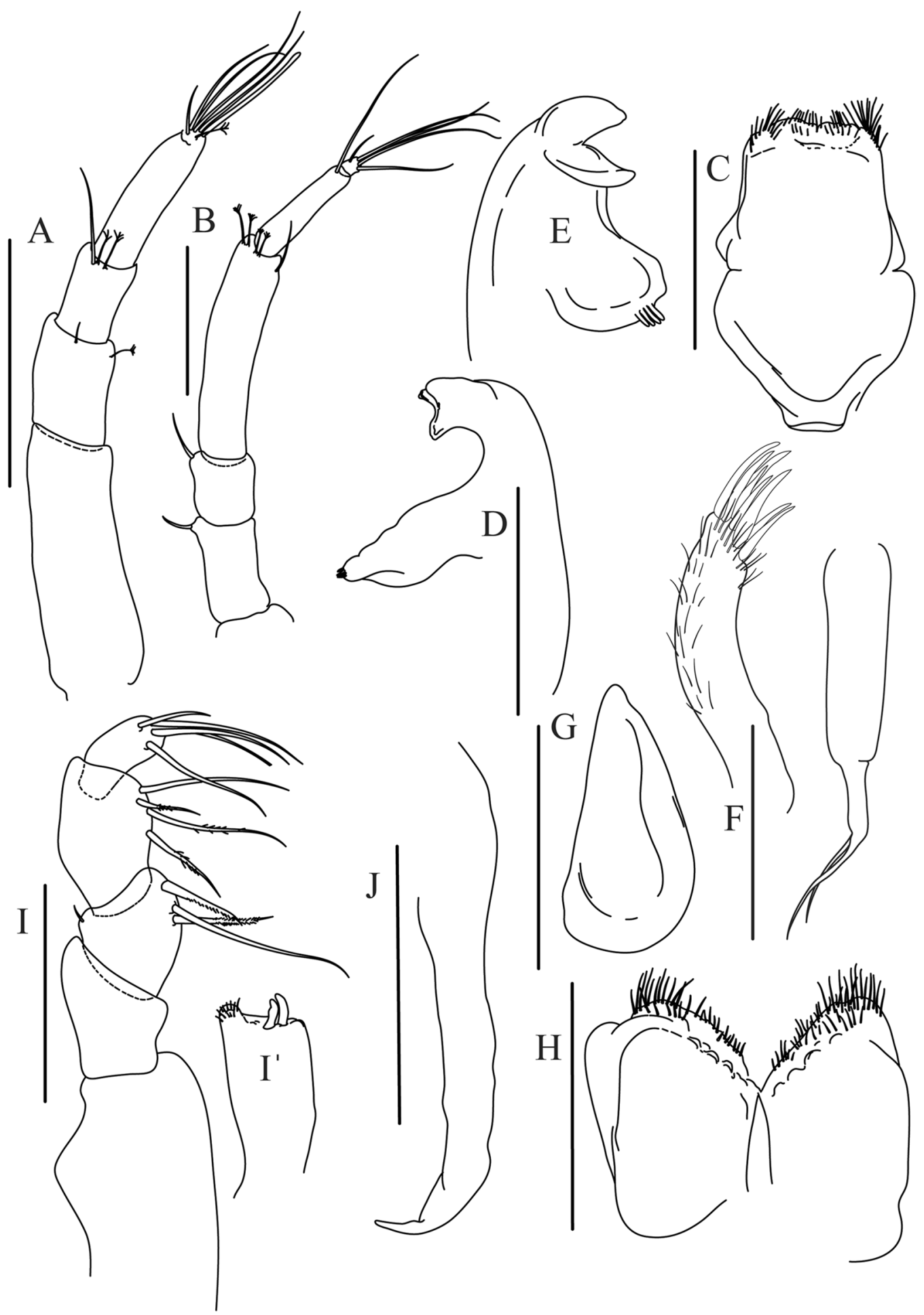

Figure 5. Paranarthrurella caudata (Kudinova-Pasternak, 1965), holotype, female (Mc-938) (A) Antennule. (B) Antenna. (C) Labrum. (D) Mandible, right. (E) Mandible, left. (F) Maxillule. (G) Maxilla. (H) Labium. (I) Maxilliped. (I') Maxilliped endite. (J) Epignath. Scale $0.1 \mathrm{~mm}$.

Mouthparts. Labrum (Fig. 5C) large, elongate; distally obtuse and with relatively sparse robust setae distally. Right mandible (Fig. 5D) incisor with smooth, weakly rounded edges, lacinia mobilis fused with incisor; molar distally elongated with four finger-shape setae. Left mandible (Fig. 5E) incisor distally simple; lacinia mobilis well developed with smooth edge; molar wide, with four finger-shape distal setae. Maxillule endite (Fig. 5F) with at least eight strong distal spines of various length and numerous setae distally and along outer margin; palp with two long simple setae. Maxilla (Fig. 5G) semitriangular. Labium (Fig. 5H) with two lobes; inner lobe with numerous robust setae on inner and distoinner margin; outer lobe small. Maxilliped (Fig. 5I) basis not observed; palp 


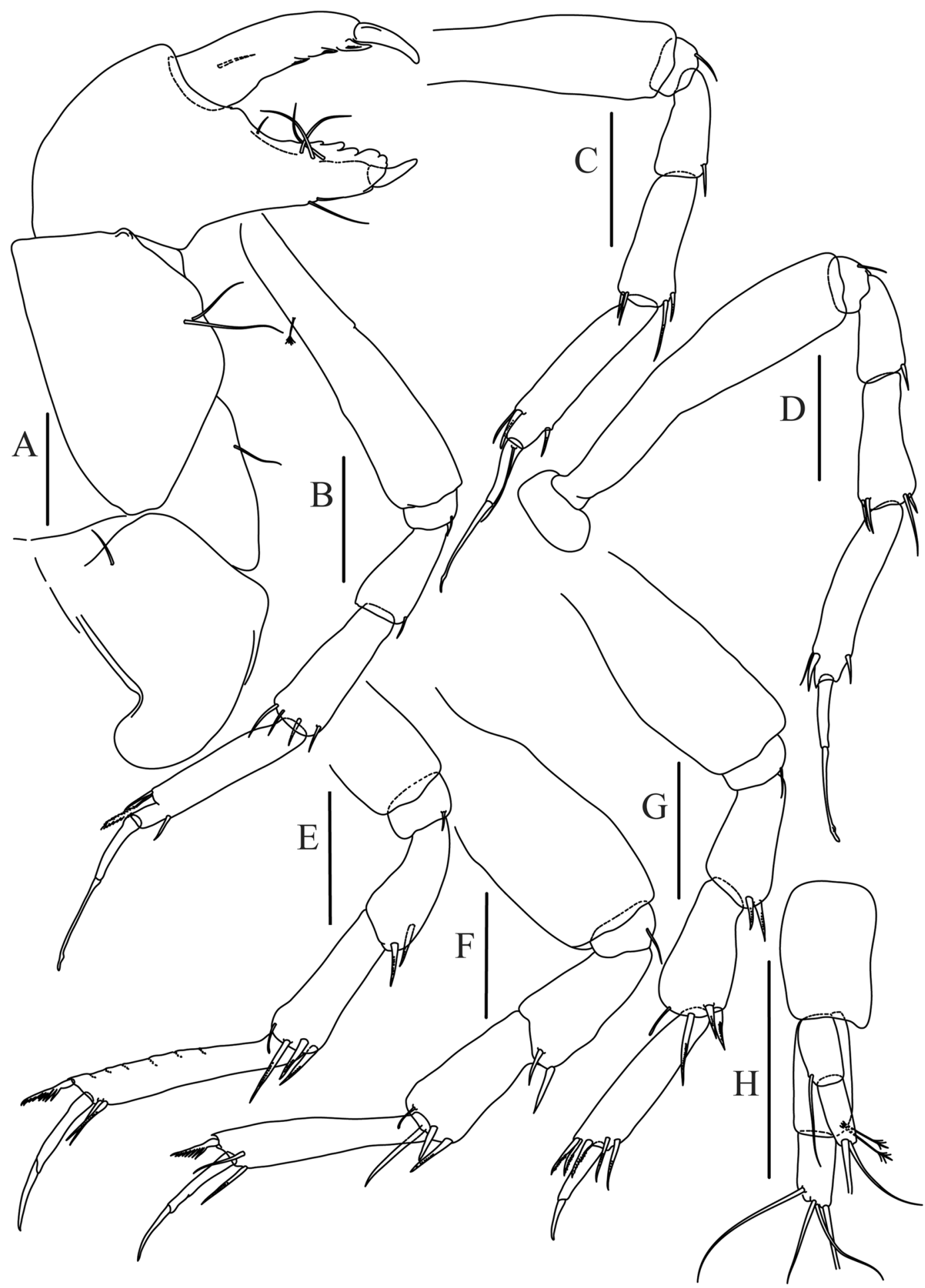

Figure 6. Paranarthrurella caudata (Kudinova-Pasternak, 1965), holotype, female (Mc-938) (A) Cheliped. (B-G) Pereopods 1-6, respectively. (H) Uropod. Scale $0.1 \mathrm{~mm}$.

article-1 1.1 L:W, naked; article-2 1.1 L:W, with one long simple and two short serrate inner setae, and small outer seta; article-3 1.5 L:W, with one simple and three sparsely serrate inner setae; article-4 2.6 L:W, with four distal/ subdistal inner setae (fifth seta not seen) and outer seta; maxilliped endites separated, narrow, $2.2 \mathrm{~L}$ :W, distally with two slender gustatory cusps; no distal seta observed. Epignath (Fig. 5J) distally pointed.

Cheliped (Fig. 6A) sclerite large semitriangular; basis 2.1 L:W, with one subdistal dorsal seta, posterior lobe small; merus wedge-shape, with ventral seta; carpus 1.6 L:W, with two ventral setae, no dorsal setae observed; chela slender, $1.2 \mathrm{x}$ carpus, 1.7 L:W; propodus (palm) with one seta near dactylus insertion, seta on inner side not 
seen; fixed finger with sharp distal spine (unguis), incisive margin well calcified, with five obtuse unequal teeth, and with three setae; fixed finger and dactylus unifacial; dactylus almost straight with three spines on inner margin and subproximal seta on inner side.

Pereopod-1 (Fig. 6B) longer than pereopods 2-3; basis $5.5 \mathrm{~L}: \mathrm{W}$, with distoproximal penicillate seta; ischium with ventral seta; merus 1.9 L:W, 0.7x carpus, with ventrodistal fine spine; carpus $3.0 \mathrm{~L}: \mathrm{W}, 0.8 \mathrm{x}$ propodus, with four short distal spines; propodus 5.4 L:W, $2.7 \mathrm{x}$ dactylus, with one subdistal ventral spine, one fine and one long serrate dorsodistal spine; dactylus $6.7 \mathrm{~L}: \mathrm{W}, 0.7 \mathrm{x}$ unguis, proximal seta not seen; unguis and dactylus about $0.9 \mathrm{x}$ propodus.

Pereopod-2 (Fig. 6C) basis broken during dissection; ischium with ventral seta; merus $2.5 \mathrm{~L}: \mathrm{W}, 0.7 \mathrm{x}$ carpus, with ventrodistal spine; carpus 3.0 L:W, $0.75 x$ propodus with four distal spine (ventrodistal spine longer); propodus 4.9 L:W and 2.9x dactylus, with small subdistal ventral spine, and two (one fine and one regular) subdistal dorsal spines; dactylus $6.1 \mathrm{~L}: \mathrm{W}, 0.7 \mathrm{x}$ unguis, with seta reaching beyond dactylus.

Pereopod-3 (Fig. 6D) similar to pereopod-2, but dactylus seta not observed.

Pereopod-4 (Fig. 6E) basis broken; ischium with one ventral seta; merus $2.7 \mathrm{~L}: \mathrm{W}, 0.9 \mathrm{x}$ carpus, with two ventrodistal serrate spines; carpus 3.6 L:W, $0.7 x$ propodus, with three distal serrate spines and rod-like dorsodistal seta; propodus 6.2 L:W, with two ventrodistal serrate spines and strongly serrate dorsodistal spine; dactylus 7.1 L:W, $1.2 \mathrm{x}$ unguis; unguis and dactylus $0.8 \mathrm{x}$ propodus.

Pereopod-5 (Fig. 6F) as pereopod-4.

Pereopod-6 (Fig. 6G) similar to pereopod-5, but propodus 3.6 L:W, with three serrate dorsodistal spines; dactylus shorter, $5.5 \mathrm{~L}: \mathrm{W}$.

Uropod (Fig. 6H) exopod with two articles, 0.7x endopod, just longer than article-1 of endopod, article-1 1.9 $\mathrm{L}: \mathrm{W}$, with distal seta, article-2 2.8 L:W, with two subdistal penicillate setae and two simple distal setae; endopod with two articles, article-1 2.1 L:W; article-2 2.0 L:W, with at least four distal setae.

Male unknown.

Distribution. The species is known only from the type locality - Bougainville Trench from 7974-8006 m depth.

Remarks. Paranarthrurella caudata was described by Kudinova-Pasternak based on five specimens of length from $3.2 \mathrm{~mm}$ to $4 \mathrm{~mm}$. From this collection, only the holotype (marked by Kudinova-Pasternak on the original label) exists and was available for our studies. For this reason, we took the advantage and partly dissected the specimen to redescribe this inadequately-described species.

$P$ c caudata is the only member of the genus with a relatively slender, elongated and almost rectangular pleotelson and with three spines on carpus of the pereopods 4-6. Those two characters combined allow $P$. caudata to be distinguished from the other members of the genus, which have a rounded pleotelson ("onion-shape" in the description of Kudinova Pasternak ${ }^{2}$ ) and four spines on carpus of the pereopods 4-6. Moreover, the apex of the pleotelson in P. caudata is robust and directed backward, but small and directed downward in all other Paranarthrurella species.

Six species: P. caudata, $P$. dissimilis, $P$. kizomba sp. nov. P. spinimaxillipeda, $P$. polonez sp. nov. and $P$. samba sp. nov. (see below) are the only known species of the genus with elongated body habitus whose body is eight or more times longer than wide. Yet, none of them has a pleonite hyposphaenium (see remarks on page 6). Paranarthrurella caudata has strongly serrated dorsodistal seta on the propodus of pereopods 4-6. This character is present in a few members of the genus (described below), as well as in P. dissimilis, although the latter has four spines on carpus of pereopod 4-6, while P. caudata has only three.

\section{Paranarthrurella arctophylax (Norman and Stebbing, 1886)}

Figures 7-9

Strongyrula arctophylax: Norman and Stebbing, 1886:12, 110, 116-117, pl. 24 Fig. III ${ }^{12}$.

Cryptocope arctophylax: Hansen, 1913: 3, 106, 110-113, pl. 11 Fig. $2 \mathrm{a}-\mathrm{k}^{8}$.

Leptognathia arctophylax: Lang, 1971: $403^{1}$; Sieg, 1986: $168^{73}$.

Paranarthrurella voeringi: Jóźwiak et al., 2009: $59^{16}$.

Material examined. Strongylura arctophylax, type (NHM 1903.5.20.8), $56^{\circ} 24^{\prime} \mathrm{N}, 11^{\circ} 19^{\prime} \mathrm{W}$, between Ireland and Rockall, $2524 \mathrm{~m}$.

Paranarthrurella arctophylax, ovigerous female (4.4 mm BL, dissected), (NI-39587), BIOICE St. 3176; neuter (non-ovigerous female) (4.3 mm BL), (NI-39666), BIOICE St. 2860; manca-3 (3.2 mm BL), (NI-39667), BIOICE St. 2863; neuter (non-ovigerous female) (4.4 mm BL), (NI-39668), BIOICE St. 2859.

Paranarthrurella cf. arctophylax, adult male (3.3 mm BL), (MCZ:IZ:47842), RV Chain, Cr. 106, St. 326.

Diagnosis. Body short (<6.5 L:W). Pereonite-1 0.5 L:W. Pleonite 2 and 4 without hyposphaenium; pleonite-3 with large, pointed hyposphaenium. Cheliped carpus 1.3 L:W. Pereopods 4-6 carpus with four spines.

Description of female, length $4.0 \mathrm{~mm}$. Body robust (Fig. 7), cephalothorax 2.3x pereonite-1. Pleon 0.3 of total body length. Pleonites 1 and 5 slightly longer than 2-4. Pleotelson just shorter than four pleonites together, rectangular in the dorsal view, apex large, pointed, directed backward.

Antennule (Fig. 8A) article-1 2.6 L:W, 2.3x article-2, with three penicillate setae at midlength and two simple and three penicillate setae distally; article-2 1.7 L:W, $1.7 \mathrm{x}$ article-3, with one simple and two penicillate setae distally; article-3 1.4 L:W, 0.5x article-4, with one simple and one penicillate setae distally; article-4 4.4 L:W, with five simple and one penicillate setae, and aesthetasc distally. 


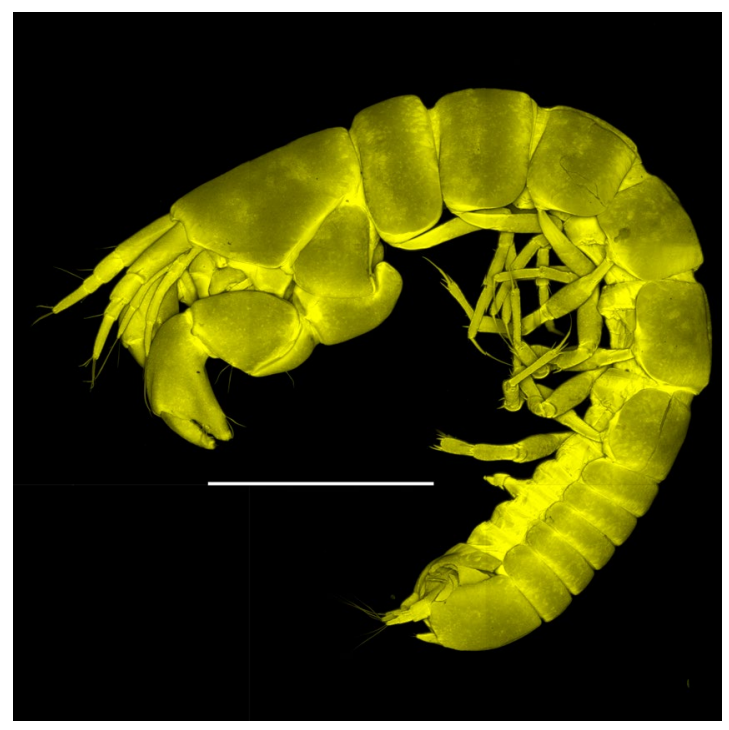

Figure 7. Paranarthrurella arctophylax (Norman and Stebbing, 1886), neuter (NI-39666) autofluorescence confocal image. Reconstructed maximum intensity projection of $3 \times 3$ area tile scan with Z-axis scan in two excitation/emission channels covering entire visible light spectrum. Scale $1 \mathrm{~mm}$.

Antenna (Fig. 8A) article-1 fused with body; article-2 2.9 L:W, 1.9x article-3, with distal seta; article-3 1.2 L:W, $0.3 \mathrm{x}$ article- 4 , with distal seta; article- $46.4 \mathrm{~L}: \mathrm{W}, 1.7 \mathrm{x}$ article-5, with one simple and one penicillate setae distally; article-5 5.2 L:W, with distal seta; article- 6 as long as wide, with four long and one short distal setae.

Mouthparts. Labrum (Fig. 8B) large, elongated; flattened and with setae distally. Left mandible (Fig. 8C) incisor distally simple; lacinia mobilis well developed with smooth edge; molar wide, with three palpate distal setae. Right mandible (Fig. 8D) incisor with smooth, gently rounded edges, lacinia mobilis fused with incisor; molar distally elongated with at least eight palpate setae (Fig. 8D'). Maxillule endite (Fig. 8E) with ten strong distal spines of various length and numerous setae distally and along outer margin; palp with two long plumose setae. Maxilla (Fig. 8G) semitriangular. Labium (Fig. 8F) with numerous setae on inner and distoinner margin and distoinner tubercle. Maxilliped (Fig. 8G) basis with short simple seta distally; palp article-1 1.1 L:W, naked; article-2 $0.8 \mathrm{~L}: \mathrm{W}$, with two simple and two serrate inner setae, and one simple outer seta; article-3 1.7 L:W, with one simple and three plumose inner setae and some microtrichia; article-4 2.4 L:W, with five distal/subdistal plumose inner setae and one simple outer seta; maxilliped endites separated, narrow, $2.7 \mathrm{~L}: \mathrm{W}$, distally with two slender tubercles (gustatory cusps) and one pair of simple setae; microtrichia also present. Epignath not found.

Cheliped (Fig. 9A) basis 5.5 L:W, naked; sclerite large rectangular; merus wedge-shape, with ventral seta; carpus 1.3 L:W, with two ventral setae, and two dorsal setae observed; chela slender, 1.2x carpus, 1.6 L:W; propodus (palm) with one long and seven setae on inner side; fixed finger with sharp distal spine (unguis), incisive margin well calcified, divided by transversal grooves into processes, and with three setae, and two setae ventrally; fixed finger and dactylus unifacial; dactylus with two spines on inner margin and subproximal seta on inner side.

Pereopod-1 (Fig. 9B) coxa with seta; basis $8.8 \mathrm{~L}: \mathrm{W}$, naked; ischium with ventral seta; merus 3.0 L:W, 1.4x carpus, with two ventrodistal setae; carpus $4.3 \mathrm{~L}: \mathrm{W}, 0.8 \mathrm{x}$ propodus, with two short dorsodistal setae and one short ventrodistal seta; propodus 7.2 L:W, 2.8x dactylus, with one subdistal ventral seta, one short and one long simple dorsodistal setae; dactylus $8.7 \mathrm{~L}: \mathrm{W}, 0.6 \mathrm{x}$ unguis, with proximal seta.

Pereopod-2 (Fig. 9C) basis 6.1 L:W, with dorsoproximal penicillate seta; ischium with ventral seta; merus 2.2 $\mathrm{L}: \mathrm{W}, 0.7 \mathrm{x}$ carpus, with two ventrodistal setae; carpus $3.4 \mathrm{~L}: \mathrm{W}, 0.75 \mathrm{x}$ propodus, with one simple and three serrate distal setae; propodus 7.2 L:W and 3.6x dactylus, with small subdistal ventral spine, seta and spine dorsally; dactylus $9.1 \mathrm{~L}: \mathrm{W}, 0.4 \mathrm{x}$ unguis, with seta reaching over dactylus.

Pereopod-3 (Fig. 9D) similar to pereopod-2, but basis with long penicillate seta ventrally.

Pereopod-4 (Fig. 9E) basis 3.5 L:W, with short dorsal seta; ischium with two ventral setae; merus $2.3 \mathrm{~L}: \mathrm{W}$, $1.1 \mathrm{x}$ carpus, with two ventrodistal serrate spines; carpus $2.2 \mathrm{~L}: \mathrm{W}, 0.6 \mathrm{x}$ propodus, with four distal serrate spines; propodus 7.2 L:W, with two ventrodistal serrate spines and strongly serrate (spinose) dorsodistal spine; dactylus 1.0 L:W, 0.9x unguis; unguis and dactylus $0.9 \mathrm{x}$ propodus.

Pereopod-5 (Fig. 9F) as pereopod-4, but no seta on basis.

Pereopod-6 (Fig. 9G) similar to pereopod-4, but carpus with additional simple seta distally; propodus with addistional serrate seta; dactylus shorter, $4.2 \mathrm{~L}: \mathrm{W}$

Distribution. The species was described for the NE Atlantic based on one specimen dredged during the Porcupine expedition at $2524 \mathrm{~m}$ depth between Ireland and Rockall. Later on, during the Ingolf expedition, new records in the David Strait and subsequently during BIOGAS expeditions in the northern Bay of Biscay, extended its depth range between 1970 and $4720 \mathrm{~m}$ (Table 5, Fig. 39). The species has been also collected in the Iceland Basin during BIOICE cruises, and it has been also recorded in the Ibero-Moroccan Gulf (Bird, pers. comm.). 


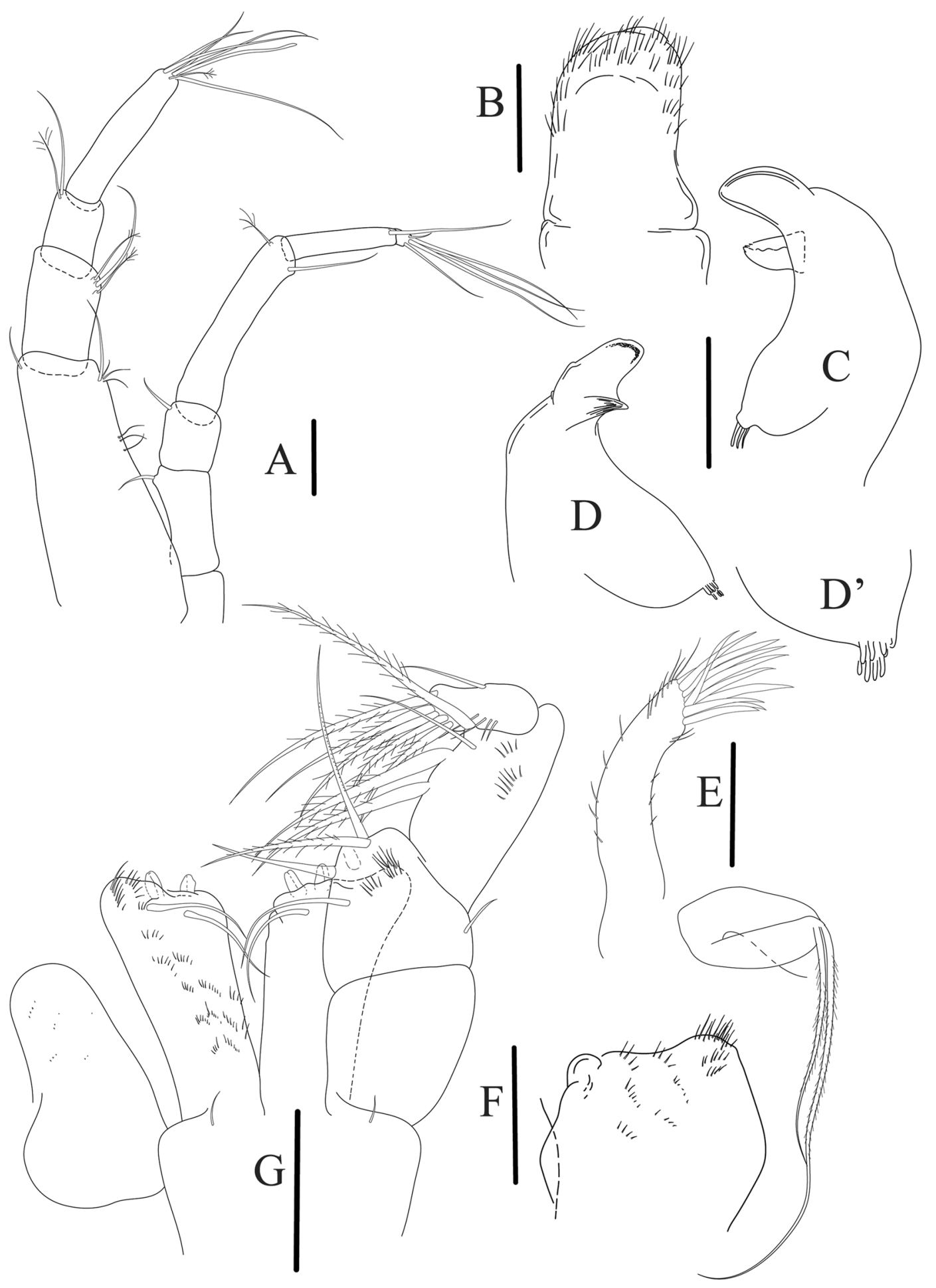

Figure 8. Paranarthrurella arctophylax (Norman and Stebbing, 1886), female (NI-39587) (A) Antennule and antenna. (B) Labrum. (C) Mandible, left. (D) Mandible, right. (E) Maxillule endite. (F) Labium. (G) Maxilla and maxilliped. Scale $0.1 \mathrm{~mm}$.

Remarks. Paranarthrurella arctophylax is the only Paranarthrurella species in the North Atlantic that has well developed hyposphaenium only on pleonite- $3^{80}$. Another species that also occurs at higher latitude in the North Atlantic is P. voeringi, whose hyposphenia is present also in pleonite 2 and 4 as well. Those two taxa have distinct temperature preferences conditioning their geographical distribution (see Table 5; also remarks under Paranarthrurella sp.2). The individual collected during Chain Cr. 106, is a fully mature male, so certain identification is not possible. However, because this individual was collected in the distributional area where P. arctophylax occurs $^{81}$, we anticipate it probably represents this species, until abiotic data could corroborate it. 


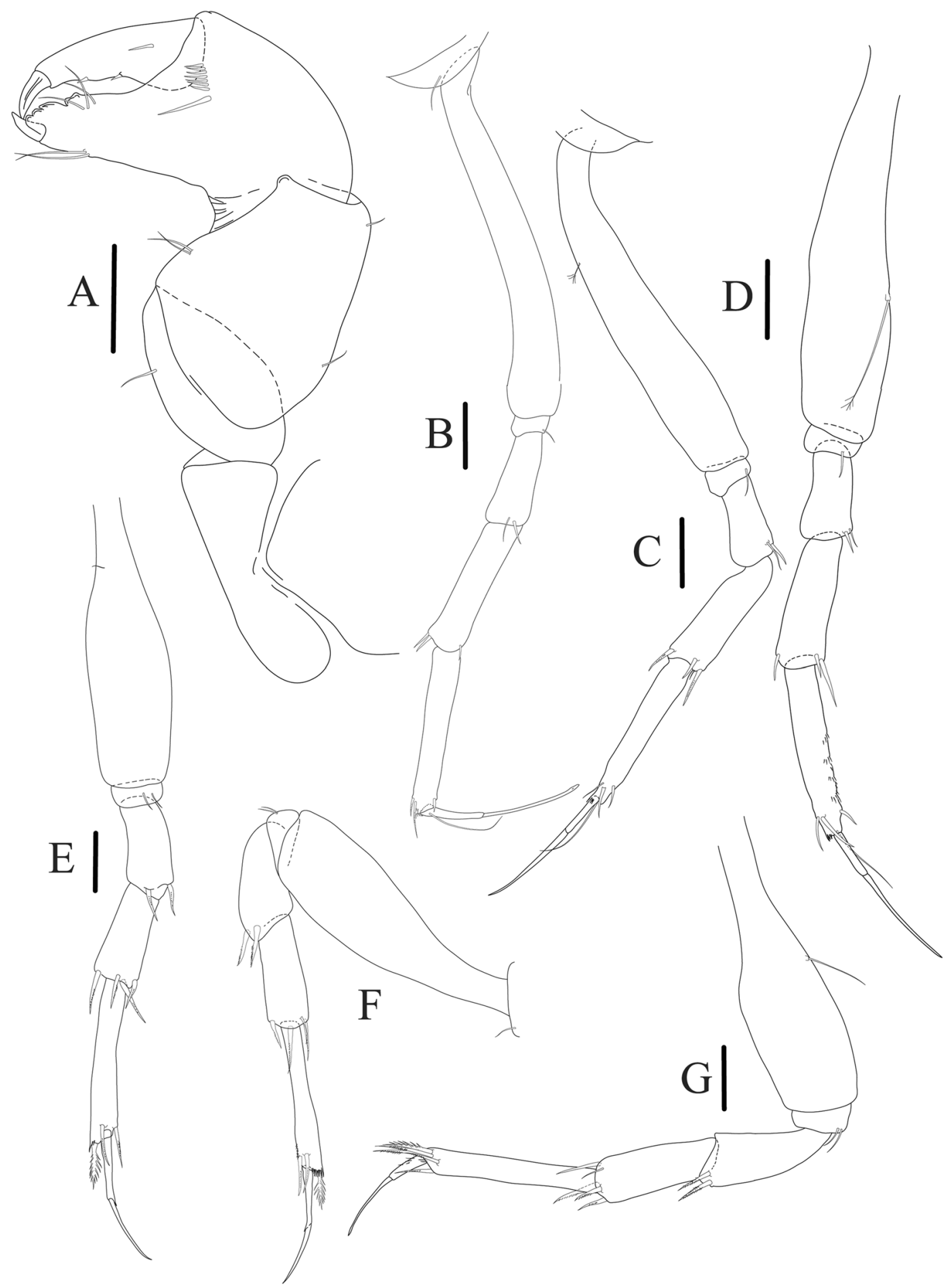

Figure 9. Paranarthrurella arctophylax (Norman and Stebbing, 1886), female (NI-39587) (A) Cheliped, outer side. (B-G) Pereopod 1-6, respectively. Scale $0.1 \mathrm{~mm}$.

\section{Paranarthrurella corroboree Błażewicz and Jóźwiak, sp. nov.}

Figures 10-13

Material examined. Holotype ovigerous female (6.2 mm BL), (J57829), SLOPE St. 25.

Paratypes: neuter (5.7 mm BL), (J61550), SLOPE St. 140; juvenile male, $5.0 \mathrm{~mm} \mathrm{BL}$, manca-3, (2.5 mm BL), (J61552), SLOPE St. 142; female dissected on slides, (5.8 mm BL) (J61551), SLOPE St. 170.

urn:lsid:zoobank.org:act:903EFAA4-8807-47FC-BEF3-2235A7A03EC7. 


\begin{tabular}{|c|c|c|c|c|c|c|c|c|}
\hline $\begin{array}{l}\text { Plotted } \\
\text { station }\end{array}$ & Expedition Station & Date & Location & Depth (m) & \begin{tabular}{|l|} 
Temperature \\
$\left({ }^{\circ} \mathrm{C}\right)$
\end{tabular} & $\begin{array}{l}\text { Salinity } \\
\text { (pps) }\end{array}$ & Sediment & Source \\
\hline \multicolumn{9}{|c|}{ P. arctophylax } \\
\hline 1 & Porcupine_St 30 & 1869 & Rockall Basin & 2523.7 & 2.83 & - & - & Norman and Stebbing $^{12}$ \\
\hline 2 & Ingolf_St 24 & $25 / 06 / 1895$ & Davis Strait & 2258 & 2.4 & 35.04 & gray deep-sea clay & Knudsen $^{108} ;$ Boeggild $^{109} ;$ Hansen $^{8}$ \\
\hline 3 & Ingolf_St 36 & 28/07/1895 & Davis Strait & 2702 & 1.5 & 34.93 & transition clay & Knudsen $^{108} ;$ Boeggild $^{109} ;$ Hansen $^{8}$ \\
\hline 4 & BIOGAS_St 1 & $1973-1980$ & Bay of Biscay & $1970-2227$ & 3.28 & 34.99 & silt & $\begin{array}{l}\text { Holdich and Bird }{ }^{81} \\
\text { Vangrieshem }^{107}, \text { Auffret }^{110}\end{array}$ \\
\hline 5 & BIOGAS_St 2 & $1973-1980$ & Bay of Biscay & $3250-3548$ & 2.67 & 34.96 & silt-very find sand & $\begin{array}{l}\text { Holdich and Bird }{ }^{81}, \\
\text { Vangrieshem }^{107}, \text { Auffret }^{110}\end{array}$ \\
\hline 6 & BIOGAS_St 3 & $1973-1974$ & Bay of Biscay & $3992-4260$ & 2.13 & 34.92 & silt & $\begin{array}{l}\text { Holdich and Bird } \\
\text { Vangrieshem }^{107}, \text { Auffret }^{110}\end{array}$ \\
\hline 7 & BIOGAS_St 4 & 1974 & Bay of Biscay & $4720-4721$ & 2.12 & 34.89 & silt-very find sand & $\begin{array}{l}\text { Holdich and Bird }{ }^{81}, \\
\text { Vangrieshem }^{107}, \text { Auffret }^{110}\end{array}$ \\
\hline 8 & BIOICE_St 2859 & $29 / 08 / 1995$ & Iceland Basin & $2270-2271$ & 2.37 & 34.95 & silty sand & https://en.ni.is/node/27982 \\
\hline 9 & BIOICE_St 2860 & $30 / 08 / 1995$ & Iceland Basin & $2295-2298$ & 2.60 & 34.96 & silty sand & https://en.ni.is/node/27982 \\
\hline 10 & BIOICE_St 2863 & $30 / 08 / 1995$ & Iceland Basin & $2400-2400$ & 2.07 & 34.95 & $\begin{array}{l}\text { sand, shell } \\
\text { fragments }\end{array}$ & https://en.ni.is/node/27982 \\
\hline 11 & BIOICE_St 3176 & $29 / 07 / 2000$ & Iceland Basin & $2537-2546$ & - & - & - & https://en.ni.is/node/27982 \\
\hline \multicolumn{9}{|c|}{ P. cf. arctophylax } \\
\hline 12 & Chain106_St 326 & $22 / 08 / 1972$ & Porcupine Seabight & 3859 & - & - & - & - \\
\hline \multicolumn{9}{|c|}{ P. voeringi } \\
\hline 13 & Norske Nordhavs_St 31 & $29 / 06 / 1876$ & Storeggen Bank & 763 & -1.0 & - & sabulous clay & Sars G.O. ${ }^{61}$ \\
\hline 14 & Norske Nordhavs_St 124 & $19 / 06 / 1877$ & off Helgeland & 640 & -0.9 & - & coarse clay & Sars G.O. ${ }^{61}$ \\
\hline 15 & Norske Nordhavs_St 248 & $08 / 08 / 1877$ & off Helgeland & 1423 & -1.4 & - & bioculina clay & Sars G.O. ${ }^{61}$ \\
\hline 16 & Ingolf_St 116 & $23 / 07 / 1896$ & S of Jan Mayen & 699 & -0.4 & - & transition clay & Knudsen $^{108} ;$ Boeggild $^{109} ;$ Hansen $^{8}$ \\
\hline 17 & Ingolf_St 117 & $23 / 07 / 1896$ & S of Jan Mayen & 1889 & -1.0 & 35.00 & globigerina clay & Knudsen $^{108} ;$ Boeggild $^{109} ;$ Hansen $^{8}$ \\
\hline 18 & Ingolf_St 138 & $10 / 08 / 1896$ & NW Faeroes & 887 & -0.6 & 35.22 & $\begin{array}{l}\text { transition deep-sea } \\
\text { clay }\end{array}$ & Knudsen $^{108}$; Boeggild ${ }^{109} ;$ Hansen $^{8}$ \\
\hline 19 & Vicking_KGS1 & $23 / 05 / 2006$ & Storega, off shore Norway & 742 & -0.7 & 33.40 & soft-bottom & $\begin{array}{l}\text { Błażewicz-Paszkowycz and } \\
\text { Bamber }^{83} \text {, Olu pers. comm. }\end{array}$ \\
\hline 20 & PS66_St 103-1 & $01 / 07 / 2004$ & Hausgarten, E Fram Strait & 1300 & -0.88 & 34.91 & silt & Jóźwiak et al. ${ }^{16}$, Budéus $^{111}$ \\
\hline 21 & PS72_St 137-5 & $12 / 07 / 2008$ & Hausgarten, E Fram Strait & 1273 & -0.84 & 34.92 & silt & $\begin{array}{l}\text { Jóźwiak et al. }{ }^{16}, \text { Beszczynska- } \\
\text { Möller \& Wisotzki }{ }^{112}\end{array}$ \\
\hline \multicolumn{9}{|c|}{ Paranarthrurella sp.1 } \\
\hline 22 & IceAGE1_St 1155 & $17 / 09 / 2011$ & NE Iceland, Norwegian Sea & $2203.8-2173.9$ & -0.75 & 34.91 & very find sand & Brix et al..$^{113,114}$ \\
\hline \multicolumn{9}{|c|}{ Paranarthrurella sp.2 } \\
\hline 23 & IceAGE1_St 1155 & $17 / 09 / 2011$ & NE Iceland, Norwegian Sea & $2203.8-2173.9$ & -0.75 & 34.91 & very find sand & Brix et al..$^{113,114}$ \\
\hline 24 & IceAGE1_St 1191 & $21 / 09 / 2011$ & NE Iceland, Norwegian Sea & $1574.7-1581.1$ & -0.74 & 34.91 & silt & Brix et al. ${ }^{113,114}$ \\
\hline
\end{tabular}

Table 5. Localities and abiotic characteristic of the stations for the northern Paranarthrurella species distributed in the North Atlantic. - data not available.

Diagnosis. Female: Body short (<6.5 L:W). Pereonite-1 0.3 L:W. Pleonites lateral margin smooth. Pleonite-2 with small and pleonite-3 with big, weakly curved backward hyposphaenium. Pleotelson rounded and swollen, apex small. Cheliped carpus 1.4 L:W. Pereopod-1 merus with two spines. Pereopods 4-6 carpus with four spines. Pereopods 4-6 propodus dorsodistal spine strongly serrate. Uropod endopod 1.5x exopod.

Etymology. In Aboriginal language 'corroboree' is an event during which the particular interaction with the Dreamtime is reached through dance and music. Noun in apposition.

Description of neuter, length $4.53 \mathrm{~mm}$. Body (Fig. 11A,B) robust, 5.2 L:W; cephalothorax 1.4 L:W, 2.35x pereonite-1. All pereonites longer than wide. Pereonites $1-6: 0.3,0.5,0.5,0.5,0.6$ and $0.5 \mathrm{~L}: \mathrm{W}$, respectively; all pereonites wider than long; pereonites $1-3$ wider proximally, pereonites $4-5$ wider in midlength. Pleon $0.25 x$ of total body length. All pleonites the same size, 1.6 W:L. Pleonite-3 with large triangular hyposphaenium, weakly curved backward, pleonite-2 with small, but wide hyposphaenium (Fig. 11C). Pleotelson 3.5x pleonite-6.

Antennule (Fig. 12A) article-1 2.8 L:W, 2.4x article-2, with three penicillate setae at midlength, one simple and three penicillate setae distally; article-2 1.5 L:W, $1.5 \mathrm{x}$ article-3, with two simple and five penicillate setae distally; article-3 1.3 L:W, 0.6x article-4, with two short simple and one long setae distally; article-4 3.8 L:W; article-5 almost completely fused with article- 4 , with four simple, one penicillate setae and one aesthetasc distally.

Antenna (Fig. 12B) 0.8 times length of antennule; article-1 fused with body; article-2 2.2 L:W, 1.5x article-3, with distodorsal seta; article-3 1.2 L:W, 0.3x article-4, with distodorsal seta; article-4 5.1 L:W, 1.8x article-5, with penicillate seta at midlength, three simple and six penicillate setae distally; article-5 five L:W, with distal seta; article- 6 minute, with one penicillate and five distal setae. 


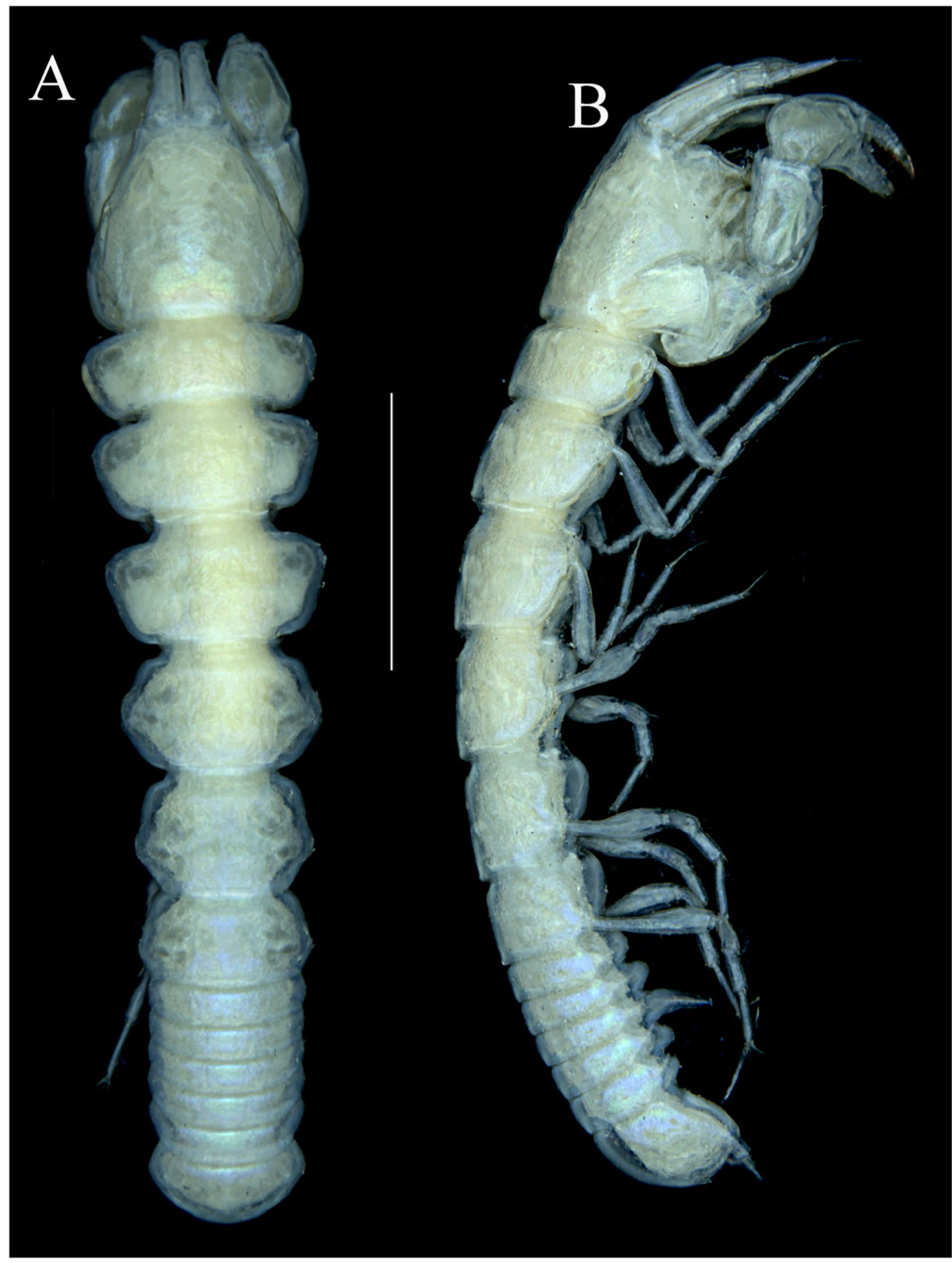

Figure 10. Paranarthrurella corroboree sp. nov., holotype, female (J57829) (A) Dorsal. (B) Lateral. Scale $1 \mathrm{~mm}$.

Mouthparts. Labrum (Fig. 12C) hood-shape, distally setose. Left mandible (Fig. 12D) incisor pointed, lacinia mobilis rounded, margins simple; molar process distally broad and rounded. Right mandible (Fig. 12E) incisor margin simple, distally rounded, lacinia mobilis in shape of small protrusion; molar process broad and rounded distally with row of seven short finger-shape spines. Maxillule endite (Fig. 12F) with nine spines, distal and dorsodistal margin setulose. Maxilla (Fig. 12F) triangular, naked. Labium (Fig. 12G) bilobed; inner lobe with numerous, short setae along distal margin; outer lobe, vestigial. Maxilliped (Fig. 12H) basis partly broken during dissection, with minute distal seta; palp article-1 1.4 L:W, naked; article-2 1.6 L:W, with three inner setae (one simple and two plumose) and one outer seta; article-3 1.6 L:W, with four inner setae (one simple and three plumose); article-4 2.1 L:W, with five plumose setae distally and one simple subdistal seta; maxilliped endites separated, with pair of slender gustatory cusps, distouter corner setulated. Epignath (Fig. 12I) distally pointed, naked. 


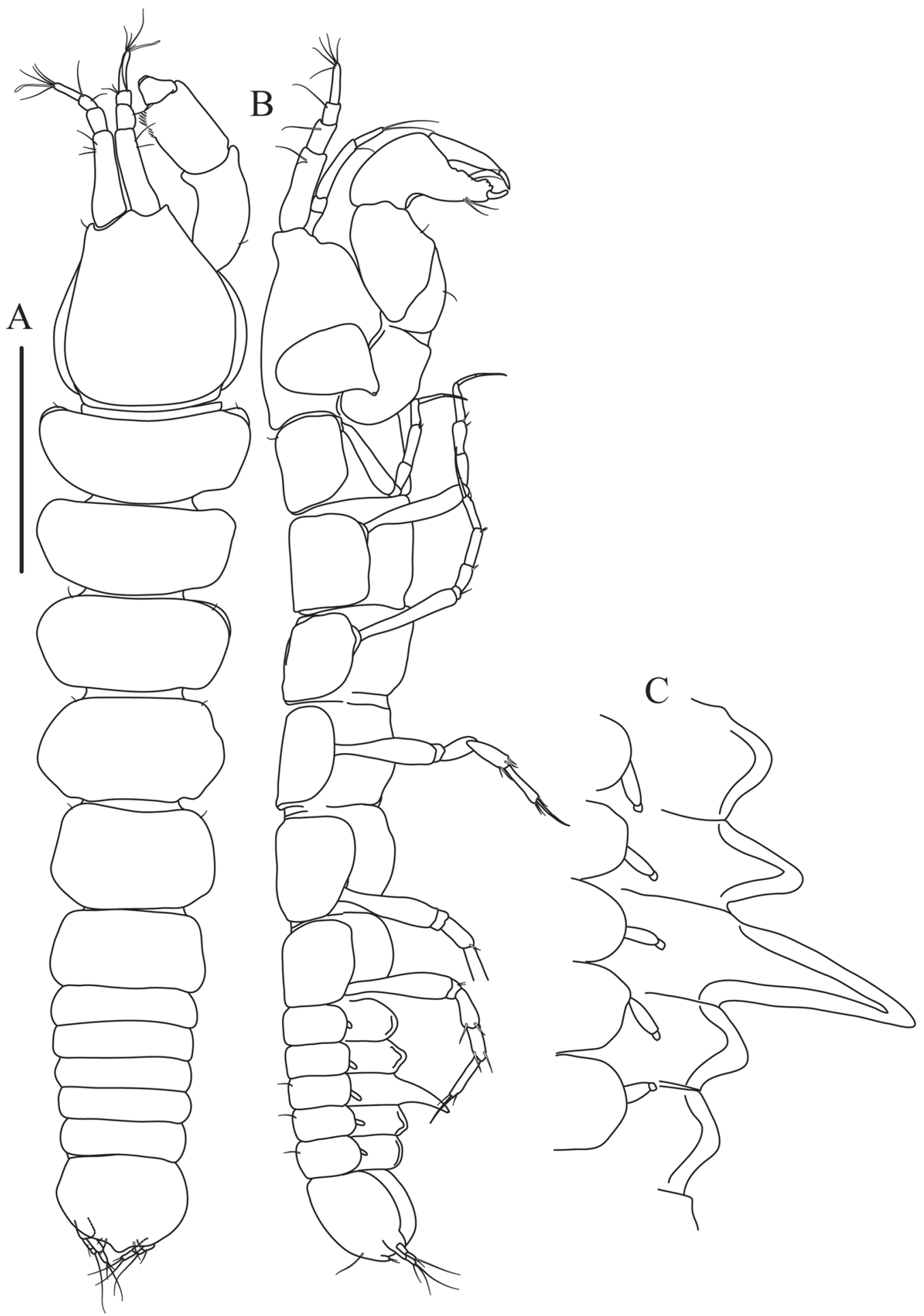

Figure 11. Paranarthrurella corroboree sp. nov., paratype, female (J61551) (A) Dorsal. (B) Lateral. (C) Pleon lateral. Scale $1 \mathrm{~mm}$.

Cheliped (Fig. 13A) sclerite large triangular; basis 1.3 L:W; merus ventral margin longer than that of carpus, with ventral seta; carpus wider medially, $1.4 \mathrm{~L}: \mathrm{W}$, with two ventral setae and one distal and one subproximal setae on dorsal margin; chela 1.2x carpus, propodus (palm) with seta near dactylus insertion, one longer and four short setae on inner side; fixed finger with two simple setae ventrally and three setae on cutting edge, incisive margin well calcified, distally with large protrusion; fixed finger and dactylus unifacial; dactylus weakly bent downward, with three blunt spines on cutting margin.

Pereopod-1 (Fig. 13B) basis 6.1 L:W, with dorsoproximal penicillate seta; ischium with ventral seta; merus 1.8 $\mathrm{L}: \mathrm{W}, 0.7 \mathrm{x}$ carpus, with fine and regular spine; carpus $3.0 \mathrm{~L}: \mathrm{W}, 0.7 \mathrm{x}$ propodus, with one serrate and three simple 


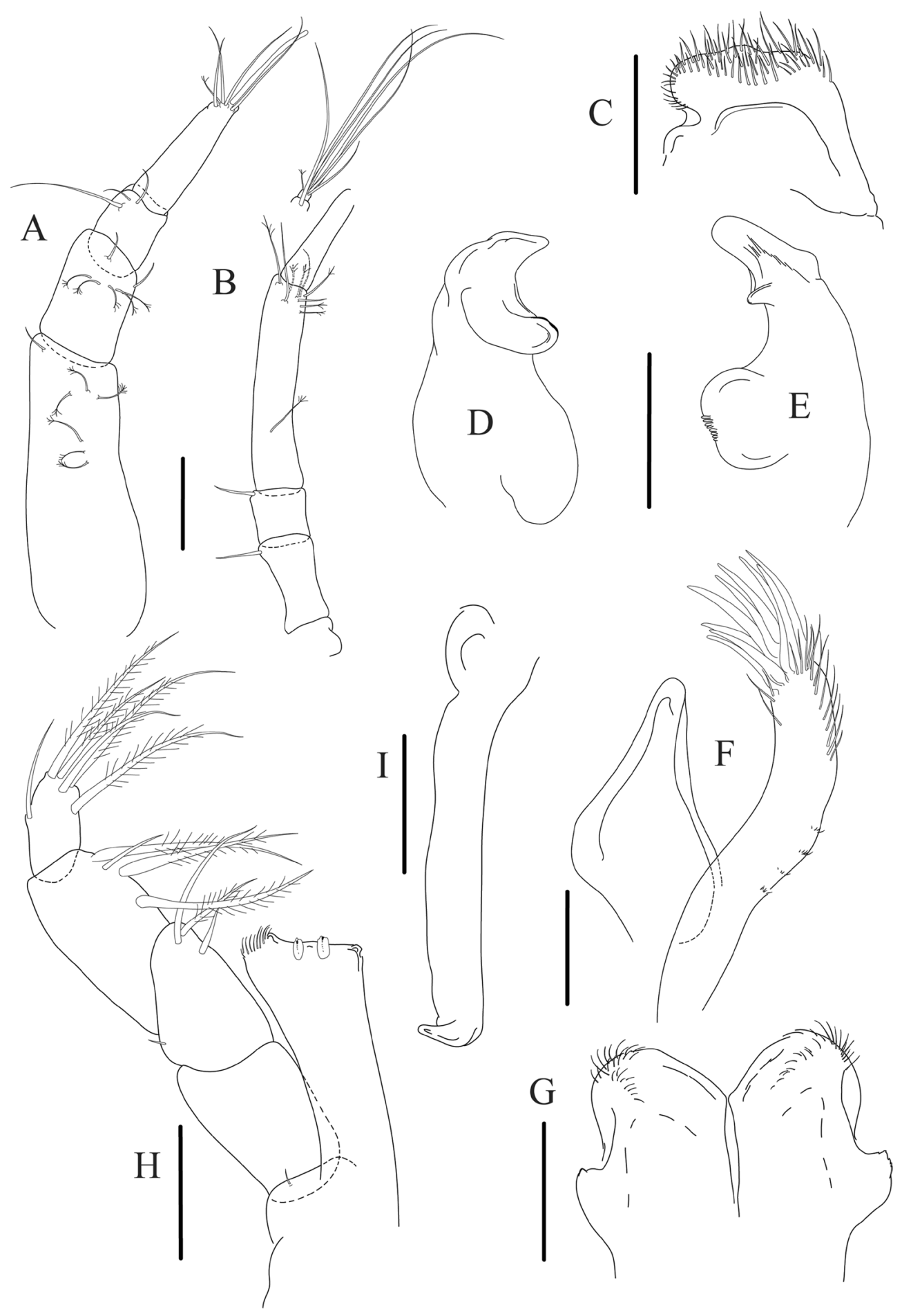

Figure 12. Paranarthrurella corroboree sp. nov., paratype, female (J61551) (A) Antennule. (B) Antenna. (C) Labrum. (D) Mandible, left. (E) Mandible, right. (F) Maxillule and maxilla. (G) Labium. (H) Maxilliped. (I) Epignath. Scale $0.1 \mathrm{~mm}$.

spines distally; propodus 5.7 L:W, 2.6x dactylus, with one seta and one serrate spine subdistally, ventral margin with microtrichia; dactylus $0.8 \mathrm{x}$ unguis; unguis and dactylus about $0.8 \mathrm{x}$ propodus.

Pereopod-2 (Fig. 13C) coxa with seta; basis $5.8 \mathrm{~L}: \mathrm{W}$, with penicillate seta dorsally; ischium with ventral seta; merus 1.9 L:W, with fine and regular spine; carpus $2.8 \mathrm{~L}: \mathrm{W}, 0.7 \mathrm{x}$ propodus, with one simple and one serrate spines and one large serrate and one small simple ventrodistal spines; propodus $4.6 \mathrm{~L}: \mathrm{W}$ and $2.1 \mathrm{x}$ dactylus, with subdistal dorsal fine and regular spines and serrate ventrodistal spine, ventral margin with microtrichia; dactylus $0.7 \mathrm{x}$ unguis, with one proximal seta; dactylus and unguis $1.1 \mathrm{x}$ propodus.

Pereopod-3 (Fig. 13D) similar to pereopod-2, dactylus seta not observed. 


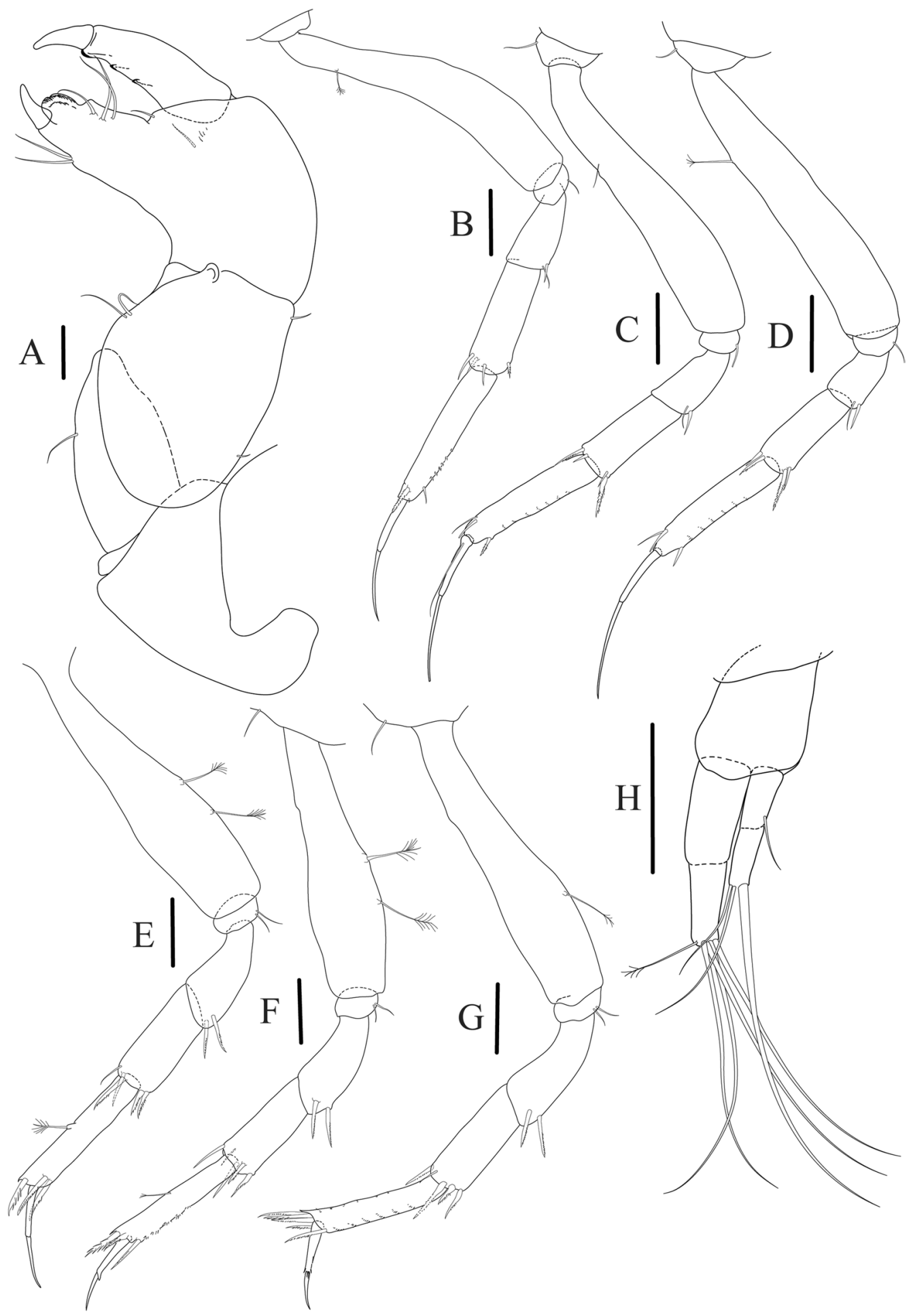

Figure 13. Paranarthrurella corroboree sp. nov., paratype, female (J61551) (A) Cheliped. (B-G) Pereopod 1-6, respectively. (H) Uropod. Scale $0.1 \mathrm{~mm}$.

Pereopod-4 (Fig. 13E) basis $4.4 \mathrm{~L}: \mathrm{W}$, with two penicillate ventral setae; ischium with two ventral setae; merus 2.2 L:W, 0.9x carpus, with two ventrodistal serrate spines; carpus $2.4 \mathrm{~L}: \mathrm{W}, 0.9 \mathrm{x}$ propodus, with simple dorsodistal seta and with four distal spines; propodus $5.7 \mathrm{~L}: \mathrm{W}$, with one penicillate dorsal seta, two ventrodistal serrate spines and strongly serrate dorsodistal spine; dactylus $0.9 \mathrm{x}$ unguis; dactylus and unguis $0.7 \mathrm{x}$ propodus.

Pereopod-5 (Fig. 13F) as pereopod-4.

Pereopod-6 (Fig. 13G) similar to pereopod-5, but basis with only one penicillate seta, propodus with two ventrodistal serrate spines and three dorsodistal spines. 
Uropod (Fig. 13H) basal article 1.4 L:W; exopod with two articles, 0.6x endopod, article-1 2.3 L:W, with simple seta, article-2 2.6 L:W, with three distal setae; endopod with two articles, article-1 2.2 L:W, naked; article-2 2.6 $\mathrm{L}: \mathrm{W}$, with one penicillate and four simple distal setae.

Distribution. Paranarthrurella corroboree sp. nov. is known from SE Australia (Bass Strait slope) from depths of 1450-1975 m.

Remarks. Paranarthrurella corroboree, is one of four species (see below) with a short body habitus and well developed hyposphaenium on pleonite-3 and small hyposphaenium on pleonite-2. Two other species with large hyposphaenium on pleonite- 3 are: $P$. voeringi that has also small on pleonite- 4 , and $P$. moonwalk $\mathrm{n}$. $\mathrm{sp}$ (see below) whose hyposphaenium on pleonite-3 is directed backward. Additionally, $P$. corroboree lacks a projection on the inner margin of the cheliped dactylus that is well developed in P. voeringi ${ }^{16}$ and has a slender endopod in uropod that is about four times as long as wide (endopod uropod is only three times as long as wide in P. moonwalk). Another species with a hyposphaenium on pleonite-3 is P. arctophylax, but it lacks hyposphaenia on pleonites 2 and 4 .

Paranarthrurella dissimilis (Lang, 1972)

For synonyms see Jóźwiak et al. ${ }^{16}$.

Diagnosis (amended) ${ }^{16}$. Body long (>8 L:W). Pleonite 2-4 without hyposphaenia. Cheliped carpus 1.4 L:W. Pereopod-1 merus with two spines. Pereopods 4-6 carpus with four spines. Pereopods 4-6 propodus dorsodistal spine strongly serrate. Uropod endopod $1.3 x$ exopod.

Remarks. From six species of Paranarthrurella which have a long body, $P$. dissimilis can be distinguished by: a rounded pleotelson with a small, pointed downward apex (large and pointed backward in P. caudata); smooth lateral margins of pleonites (pointed in P. polonez); by presence of strongly serrated spine on the propodus of pereopods 4-6; P. spinimaxillipeda, P. samba and P. kizomba have weakly serrated spine at this location.

Distribution. The species is known only from the type locality in the Sargasso Sea (NW Atlantic), at $6000 \mathrm{~m}$ depth.

Paranarthrurella kizomba Błażewicz and Frutos sp. nov.

Figures 14 and 15

Material examined. Holotype neuter (3.1 mm BL), (ZMH K-55987), RV Sonne, SO-237, Vema-TRANSIT, St. 6-8.

Diagnosis. Female. Body elongate. Pleonites lateral margin smooth. Pleonites 2-4 without hyposphaenium. Pleon rounded and swollen, apex small. Cheliped carpus $1.3 \mathrm{~L}$ :W. Pereopod-1 merus with one spine. Pereopods 4-6 carpus with four spines. Pereopods 4-6 propodus dorsodistal spine finely serrate. Uropod endopod 1.6x exopod.

Etymology. The species name is given for a dance with African origin in Angola. Noun in apposition.

Description of neuter, length $3.1 \mathrm{~mm}$. Body elongate (not illustrated because of poor condition), 9.6 L:W; cephalothorax about $1.5 \mathrm{~L}$ :W, $1.7 \mathrm{x}$ pereonite-1. Pleon $0.2 \mathrm{x}$ total body length. All pleonites of the same size. Pleotelson 4.0x pleonite-5, swollen, apex small, directed downward.

Antennule (Fig. 14A) article-1 3.5 L:W, 2.5x article-2, with three middle penicillate setae (broken), seven penicillate setae arranged in vertical row to main axis of the article and simple distal seta; article-2 1.5 L:W, 1.3x article-3, with nine penicillate distal setae arranged in vertical row to main axis of the article and short distal simple seta; article-3 1.7 L:W, 0.5x article-4, with two simple and three penicillate setae distally; article-4 4.2 L:W; article-5 vestigial, with five simple distal setae and one aesthetasc.

Antenna (Fig. 14A) 0.7 times length of antennule; article-1 fused with body; article-2 1.8 L:W, 1.4x article-3, with short distodorsal seta, situated on apophysis in right angle to axis of the article; article-3 1.7 L:W, $1.3 \mathrm{x}$ article-4, with short distodorsal seta situated in right angle to axis of the article; article-4 5.5 L:W, 2.0x article-5, with microtrichia on dorsal margin, and at least seven short distal and subdistal setae; article-5 4.3 L:W, with distal seta; article- 6 as long as wide, with four long and one short distal setae.

Mouthparts. Labrum (Fig. 14B) distally rounded and with relatively sparse and long setae distally. Left mandible (Fig. 14C,C') incisor with smooth margin; lacinia mobilis little longer than incisor, with smooth edge; molar distally rounded, with blunt spine and eight, weak finger-shape setae (Fig. 14C"). Maxillule endite (Fig. 14D,D') with nine strong distal spines and numerous setae along outer margin. Maxilla (Fig. 14D) semitriangular. Labium (Fig. 14E) with two lobes; inner lobe with numerous spines distally; outer lobe smaller than inner lobe, finely setose. Maxilliped (Fig. 14F) basis 1.8 L:W, with small distal seta; palp article-1 1.2 L:W, naked; article-2 as long as wide, with three serrate inner setae (two short, one long); article-3 1.7 L:W, with four sparsely hirsute inner setae; article-4 1.7 L:W, with five distal and subdistal, sparsely setose inner setae and one outer seta (Fig. 14F"); maxilliped endites separated, narrow, 2.0 L:W, with two setae and two slender gustatory cusps on distal margin, distolateral corner setose (Fig. 14F'). Epignath not seen.

Cheliped (Fig. 15A,B) sclerite large semitriangular; basis $1.8 \mathrm{~L}: \mathrm{W}$, with one subdistal dorsal seta; merus wedge-shape, with ventral seta; carpus 1.2 L:W, with two ventral setae, one subdistal and one subproximal dorsal setae; chela rather slender $1.2 \mathrm{x}$ carpus, $1.5 \mathrm{~L}: \mathrm{W}$; propodus (palm) with seta near dactylus insertion and four setae (one long, three short) and microtrichia on inner side; fixed finger as long as wide, with robust distal spine 


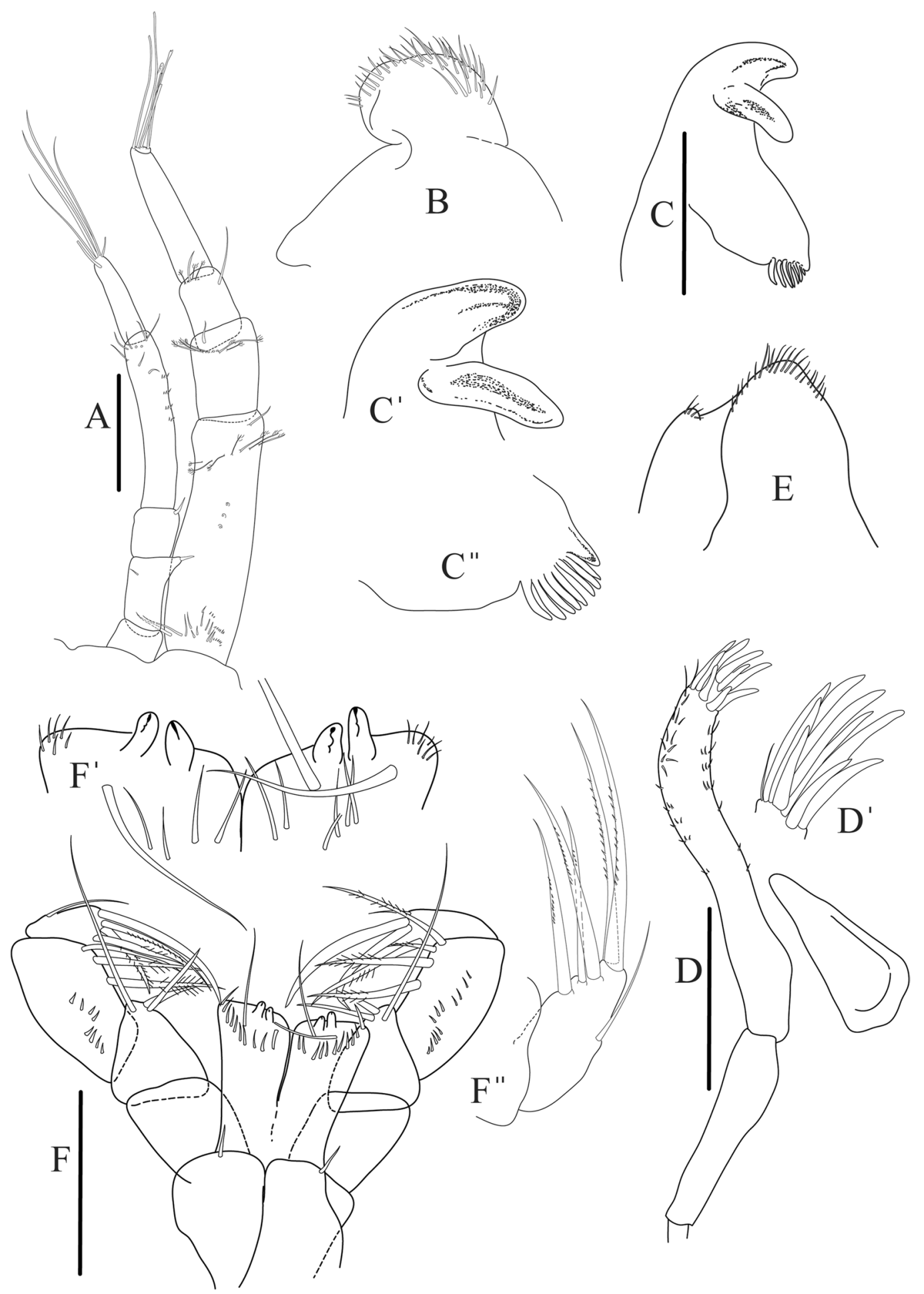

Figure 14. Paranarthrurella kizomba sp. nov., holotype neuter (ZMH K-55987) (A) Antennule and antenna. (B) Labrum. (C) Mandible, left. (C') mandible left incisor details. (C') Mandible left, molar details (D) Maxillule and maxilla. (D') Maxillule endite details. (E) Labium. (F) Maxilliped. (F') Maxilliped endites, details. (F”) Maxilliped, palp article- 4 details. Scale $0.1 \mathrm{~mm}$.

(unguis); incisive margin irregular and well calcified; with obtuse distal tooth; three setae on cutting edge and two ventral setae; fixed finger and dactylus unifacial; dactylus almost straight $3.3 \mathrm{~L}: \mathrm{W}$, with three short spines on cutting margin and two subproximal setae on inner side.

Pereopod-1 (Fig. 15C) longer than pereopods 2-3; basis $6.5 \mathrm{~L}: \mathrm{W}$, naked; ischium with seta; merus $1.8 \mathrm{~L}: \mathrm{W}$, $0.7 \mathrm{x}$ carpus, with one short distal spine; carpus $4.0 \mathrm{~L}: \mathrm{W}, 0.8 \mathrm{x}$ propodus, with four distal spines; propodus $5.6 \mathrm{~L}: \mathrm{W}$, 


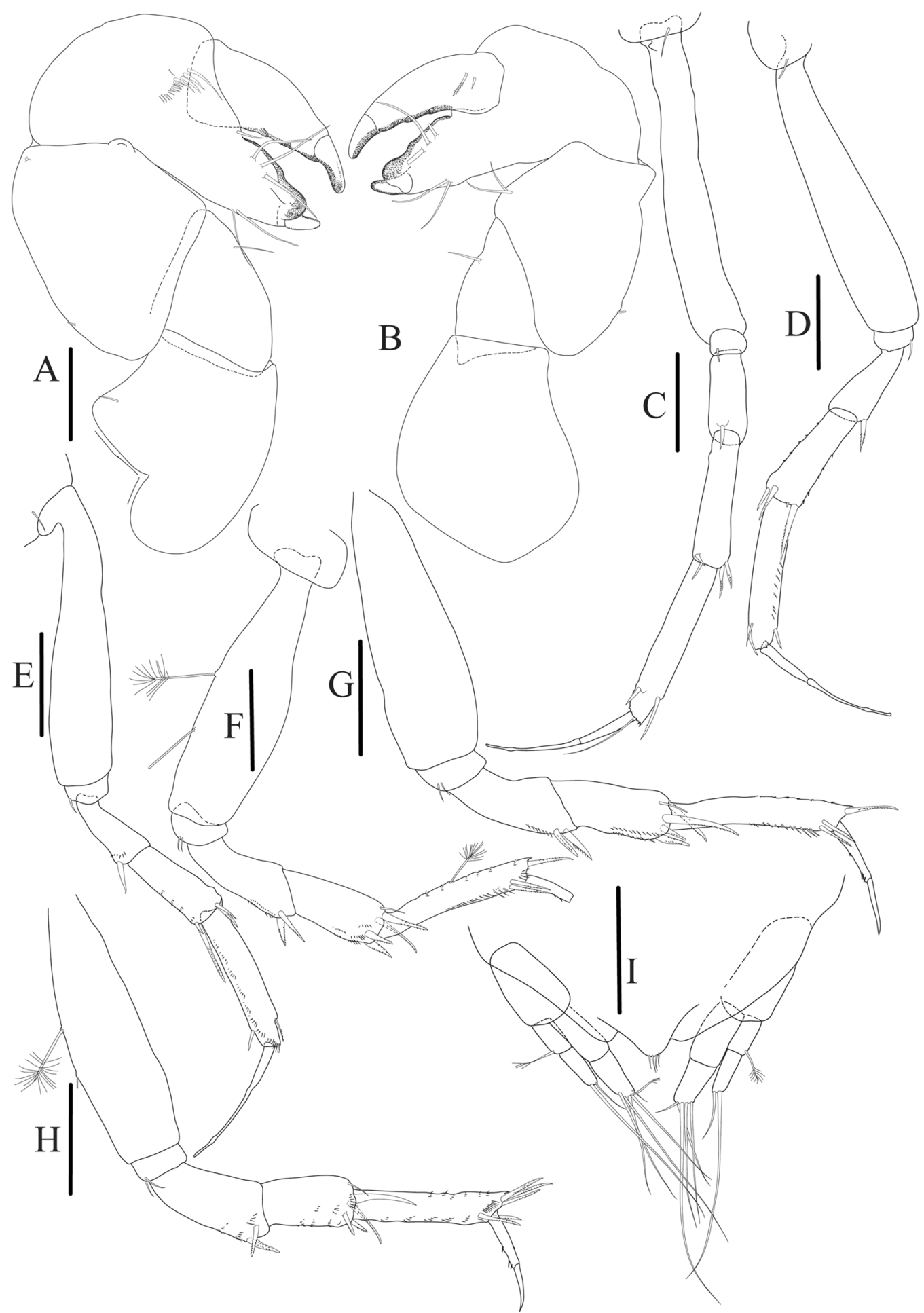

Figure 15. Paranarthrurella kizomba sp. nov., holotype neuter (ZMH K-55987) (A) Cheliped, outer side. (B) Cheliped, inner side. (C-H) Pereopod 1-6, respectively. (I) Uropod. Scale $0.1 \mathrm{~mm}$.

2.9x dactylus, with one subdistal ventral short spine and one subdistal dorsal spine; dactylus 8.0 L:W, 2.0x unguis, with seta reaching 0.3 of unguis; unguis and dactylus about as long as propodus.

Pereopod-2 (Fig. 15D) coxa with seta; basis $5.4 \mathrm{~L}: \mathrm{W}$, naked; ischium with ventral seta; merus $2.5 \mathrm{~L}: \mathrm{W}, 0.8 \mathrm{x}$ carpus, with serrate ventrodistal spine; carpus $3.1 \mathrm{~L}: \mathrm{W}, 0.7 \mathrm{x}$ propodus, with one long and two short serrate spines and one minute spine distally; propodus 5.0 L:W and 2.6x dactylus, with subdistal ventral spine and subdistal fine and regular spines dorsodistally; dactylus 7.0 L:W, $0.6 \mathrm{x}$ unguis, with seta reaching 0.3 unguis, proximal seta not seen; dactylus and unguis as long as propodus.

Pereopod-3 (Fig. 15E) as pereopod-2. 


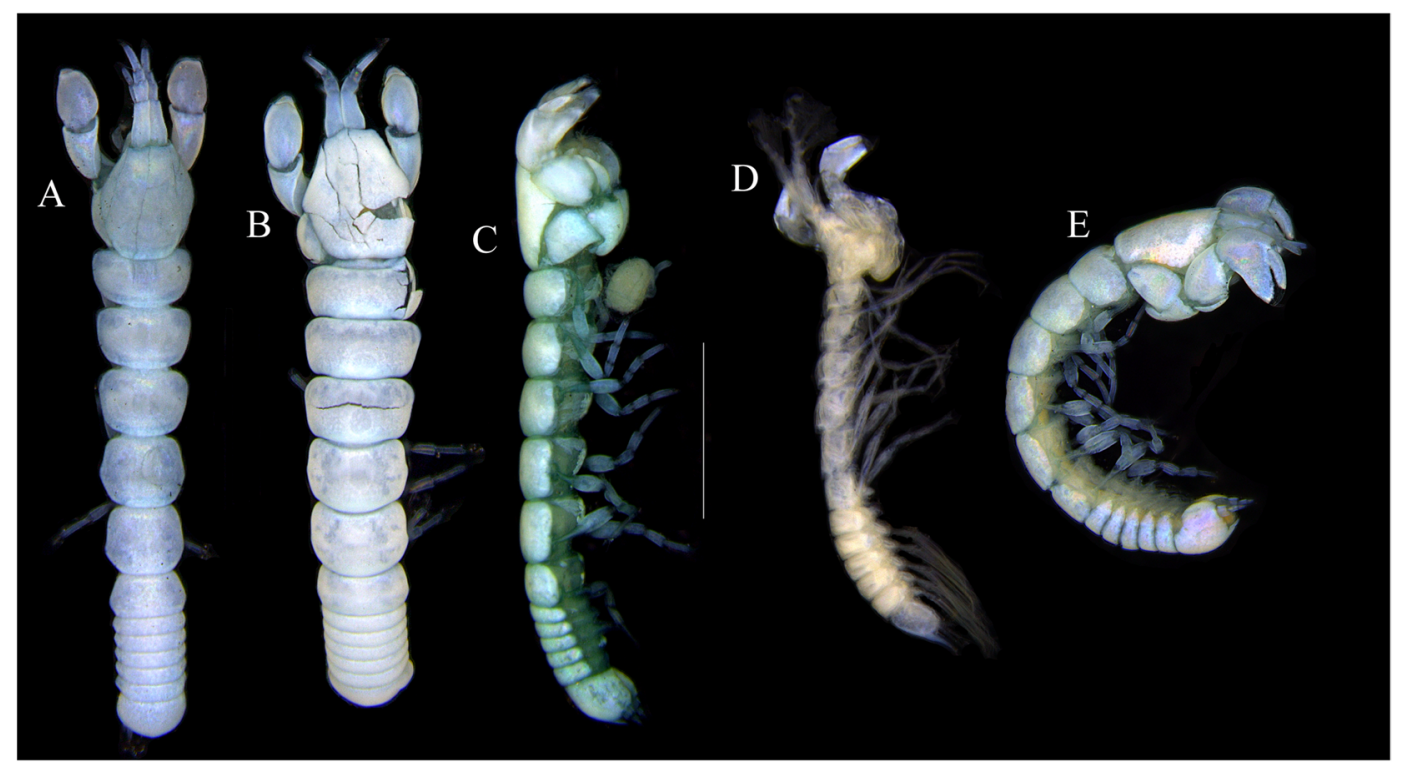

Figure 16. Species of the genus Paranarthrurella from Gay-Head Bermuda: (A) P. rocknroll sp. nov. (B-E) P. moonwalk sp. nov. (A) P. rocknroll sp. nov. holotype neuter (MCZ:IZ: 48498) dorsal view. (B) P. moonwalk sp. nov. paratype, male (MCZ:IZ: 48389). (C) Holotype, neuter (MCZ:IZ: 48323). (D) Paratype, male (MCZ: IZ: 49389), illustrated and dissected. (E) Paratype, juvenile male (MCZ:IZ:49378). Scale $1 \mathrm{~mm}$.

Pereopod-4 (Fig. 15F) basis 3.2 L:W, with two penicillate ventral setae; ischium with two ventral setae; merus 3.0 L:W, $1.1 x$ carpus, with two serrate ventrodistal spines; carpus $2.4 \mathrm{~L}: \mathrm{W}, 0.7 \mathrm{x}$ propodus, with four distal serrate spines and rod-like seta distally; propodus $8.0 \mathrm{~L}: \mathrm{W}$, with middle penicillate seta on dorsal margin, two ventrodistal serrate spines and dorsodistal serrate spine; merus, carpus and propodus with microtrichia ventrally; dactylus 6.7 L:W; unguis broken.

Pereopod-5 (Fig. 15G) as pereopod-4, but no penicillate seta on basis and propodus.

Pereopod-6 (Fig. 15H) similar to pereopod-5, but propodus with three dorsodistal serrate spines.

Uropod (Fig. 15I) basal article 2.3 L:W; exopod with two articles, $0.7 \mathrm{x}$ endopod, just longer than endopod article-1, article-1 2.1 L:W, with distal penicillate seta, article-2 $2.8 \mathrm{~L}: \mathrm{W}$, with two distal setae; endopod with two articles, article-1 2.1 L:W, naked, article-2 2.0 L:W, with five simple and one penicillate setae distally.

Distribution. The species is known only from the type locality, NE Atlantic (Vema Fracture Zone), from 5127-5137 m depth. At this station the environmental parameters were as follow: bottom temperature: $2.21^{\circ} \mathrm{C}$, bottom $\mathrm{O}_{2}: 245.4 \mu \mathrm{M}$, bottom current: $2.1 \mathrm{~cm} / \mathrm{s}$.

Remarks. Paranarthrurella kizomba sp. nov. is one of eight species of Paranarthrurella present in the Atlantic, and the only one with long body habitus and no pleonite hyposphaenia. It is one of five species that have an elongate body $(>8 \mathrm{~L} / \mathrm{W})$ and regular (wide) pleotelson with small apex directed downward (large apex directed backward in P. caudata). The new species is readily distinguished from $P$. polone $z$ sp. nov. (see below) by presence of the smooth lateral margins of pleonites (pointed in P. polonez). The distal spine in propodus of pereopod 4-6 is weakly serrate in $P$. kizomba, in contrast to $P$. dissimilis (strongly serrate spine). Furthermore, P. kizomba can be distinguished from P. spinimaxillipeda (from Central Pacific) by having only one spine on the merus of the pereopods 1-3 (two in P. spinimaxillipeda). Finally, P. kizomba elongated seta in the maxilliped palp article-3, that is equal to the other setae in P. samba sp. nov. (see below).

\section{Paranarthrurella moonwalk Błażewicz and Jóźwiak sp. nov.}

Figures 16-19

Material examined. Holotype neuter, with tantulocarid (3.4 mm BL) (MCZ:IZ:48323), RV Atlantis II, Cr. 30 St. 131.

Paratypes: neuter (4.1 mm BL, dissected), (MCZ:IZ:149577), the same locality as holotype; male (3.9 mm BL, partly dissected), (MCZ:IZ:49389), RV Atlantis II, Cr. 24, St. 115; two mancas-2 (1.8-1.9 mm BL) two mancas-3 (2.4-2.7 mm BL), (MCZ:IZ:49382), RV Knorr Cr. 35, St. 340; two mancas (2.0-2.1 mm BL), (MCZ:IZ:49384), RV Chain, Cr. 88, St. 210; neuter (3.3 mm BL) (MCZ:IZ:149576), RV Atlantis II, Cr. 24, St. 115.

Additional material. Paranarthrurella cf. moonwalk, one juvenile male (4.1 mm BL), (MCZ:IZ:49378), RV Knorr, Cr. 35. St 340. 


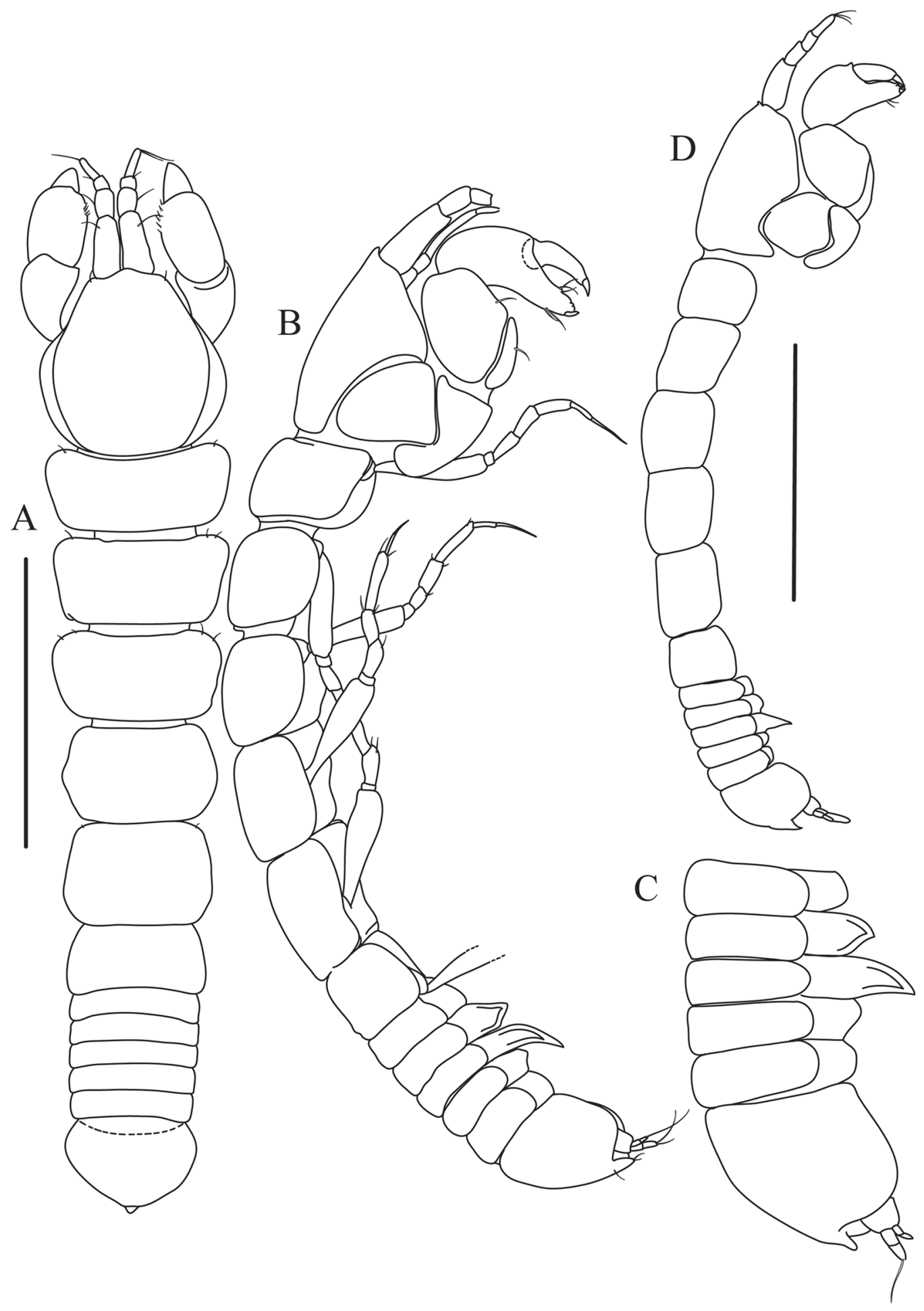

Figure 17. Paranarthrurella moonwalk sp. nov., holotype neuter (MCZ:IZ:48323), (A) Dorsal, (B) Lateral. (C) Female pleon lateral. (D) paratype, juvenile male, lateral (MCZ:IZ:49378). Scale $1 \mathrm{~mm}$.

Diagnosis. Female. Body short (<6.5 L:W). Pereonite-1 0.4 L:W. Pleonites lateral margin smooth. Pleonites 2 and 3 with hyposphaenium small and large, weakly pointed backward, respectively. Pleotelson rounded and swollen, apex small, pointed downward. Cheliped carpus 1.1 L:W. Pereopod-1 merus with two short and fine spines. Pereopods 4-6 carpus with four slender spines. Pereopods 4-6 propodus dorsodistal spine strongly serrate. Uropod endopod 1.5x exopod.

Etymology. The species name is given for a dance initiated by Michael Jackson. Noun in apposition. 


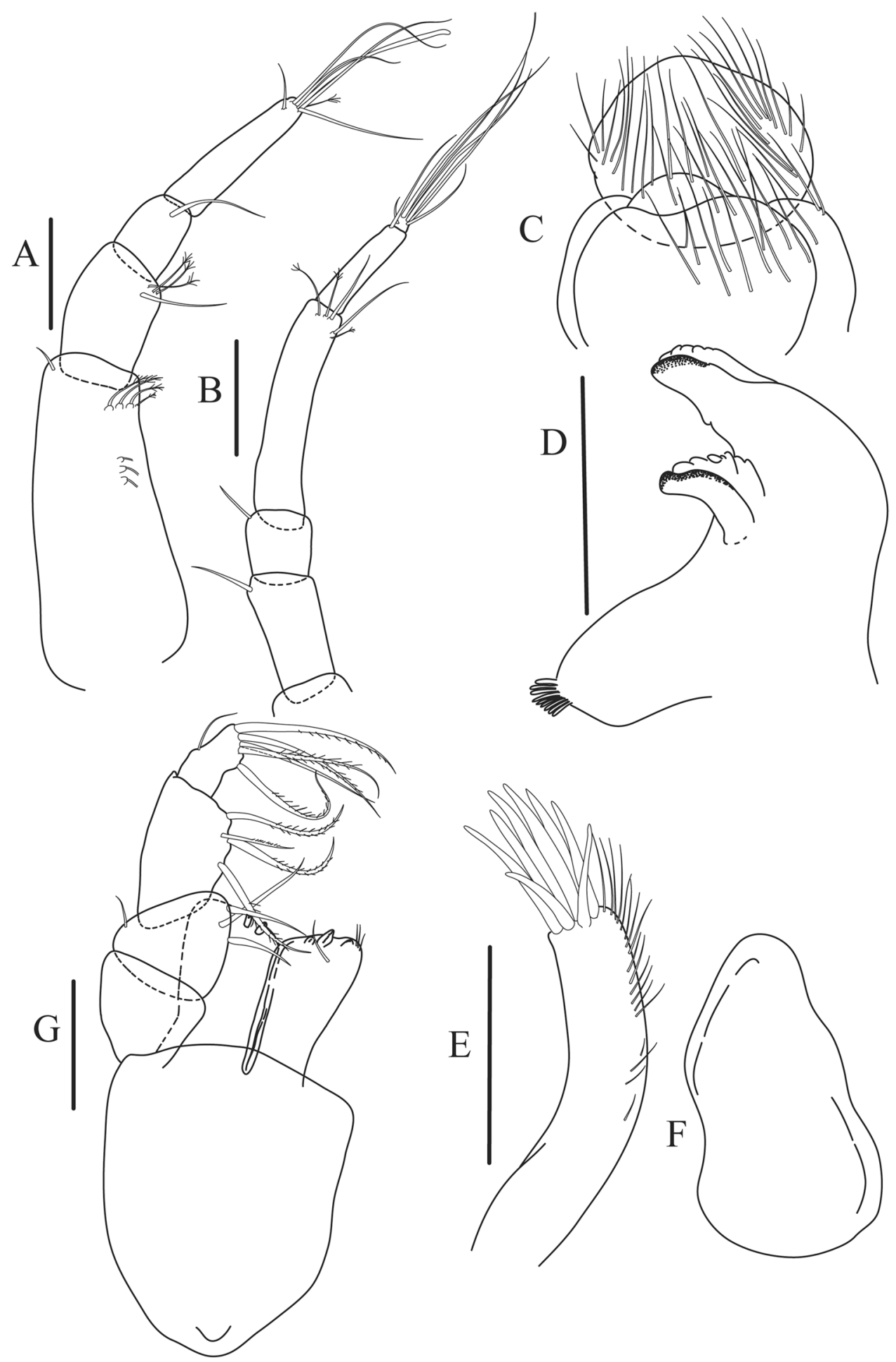

Figure 18. Paranarthrurella moonwalk sp. nov., paratype neuter (MCZ:IZ:149577) (A) Antennule. (B) Antenna. (C) Labrum. (D) Mandible, left. (E) Maxillula. (F) Maxilla. (G) Maxilliped. Scale $0.1 \mathrm{~mm}$.

Description of neuter, length $4.2 \mathrm{~mm}$. Body (Figs 16B-E and 17A,B) robust, 5.6 L:W; cephalothorax 1.2 L:W, $2.4 \mathrm{x}$ pereonite-1. Pereonites $1-6: 0.4,0.5,0.5,0.6,0.7$ and $0.45 \mathrm{~L}: \mathrm{W}$, respectively; all pereonites wider than long; pereonites 1-2 wider proximally, pereonites 3-5 weakly rounded. Pleon 0.25 of total body length. All pleonites the same size, $0.25 \mathrm{~L}: \mathrm{W}$, pleonites $2-3$ with hyposphaenium small and large, weakly pointed backward, respectively. Pleotelson 3.0x pleonite-5.

Antennule (Fig. 18A) article-1 2.7 L:W, 2.3x article-2, with three middle penicillate setae (broken), four penicillate distal setae and one simple distal seta; article-2 1.7 L:W, 1.7x article-3, with one simple and three penicillate 


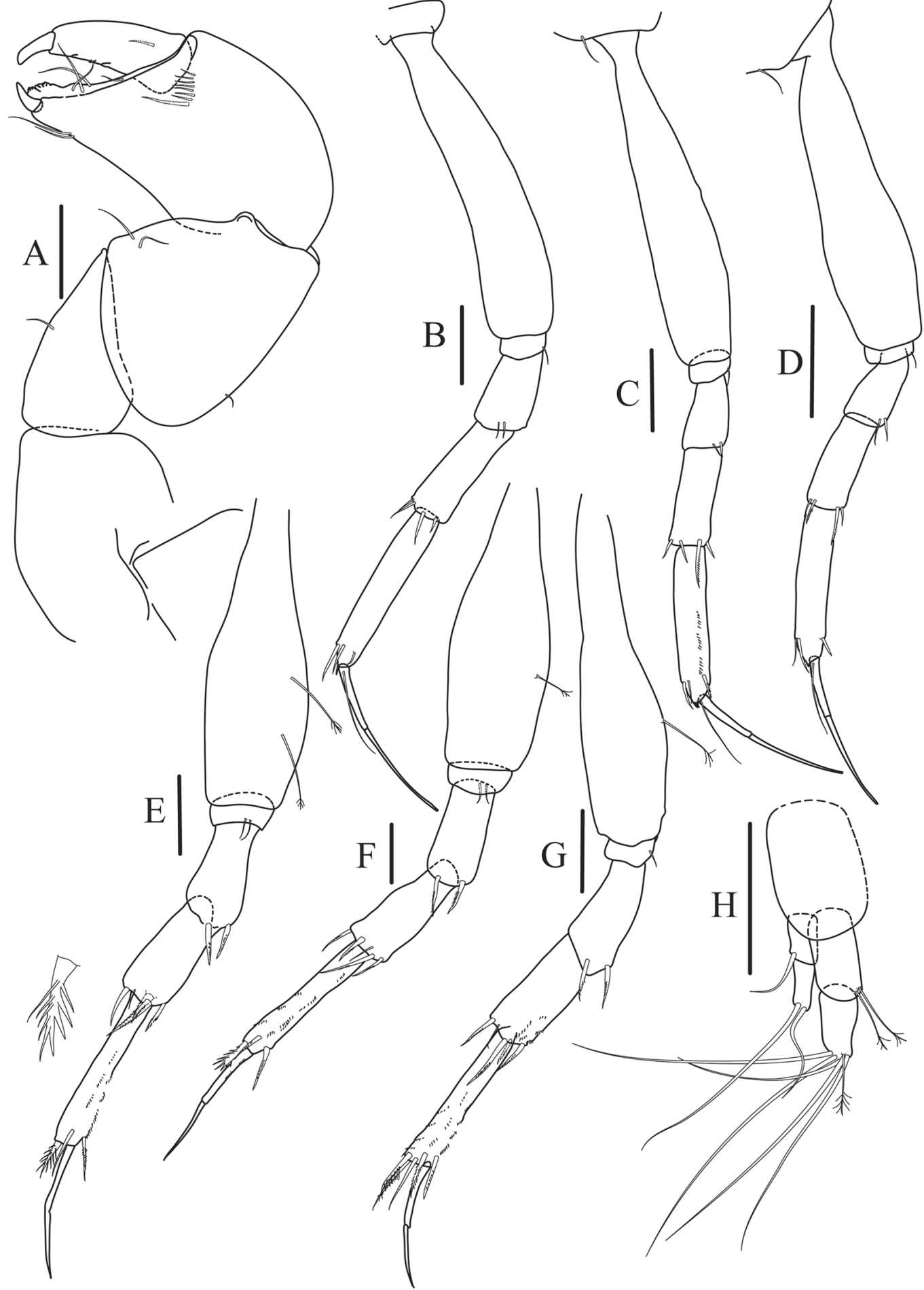

Figure 19. Paranarthrurella moonwalk sp. nov., paratype neuter (MCZ:IZ:149577) (A) Cheliped. (B-G) Pereopods 1-6, respectively. (H) Uropod. Scale $0.1 \mathrm{~mm}$.

distal setae; article-3 1.4 L:W, 0.5x article-4, with long distal seta; article-4 4.0 L:W; article-5, fully fused with article-4, with four long, one short and one penicillate distal setae, and aesthetasc.

Antenna (Fig. 18B) 0.85 times length of antennule; article-1 fused with body; article-2 2.1 L:W, 1.7x article-3, with distodorsal seta, situated in right angle to axis of the article; article-3 1.2 L:W, $0.3 \mathrm{x}$ article-4, with distodorsal seta, situated in right angle to axis of the article; article-4 5.5 L:W, $2.1 \mathrm{x}$ article-5, with two simple and three penicillate setae distally; article-5 4.2 L:W, with distal seta; article-6 1.2 L:W, with four long and two short distal setae.

Mouthparts. Labrum (Fig. 18C) large, distally rounded and with relatively dense and long setae. Right mandible not observed. Left mandible (Fig. 18D) incisor narrow with undulated margin; lacinia mobilis well developed, 
shorter than incisor, with undulate margin; molar distally rounded, with nine, weak finger-shape setae. Maxillule endite (Fig. 18E) with nine strong distal spines and numerous setae along outer margin; palp not seen. Maxilla (Fig. 18F) semi-triangular. Labium not observed. Maxilliped (Fig. 18G) basis 1.6 L:W, naked; palp article-1 1.1 L:W, naked; article-2 0.9 L:W, with three inner setae and outer seta; article-3 1.6 L:W, with four inner, sparsely serrate setae; article-4 1.8 L:W, with five distal and subdistal, sparsely setose inner setae and one outer seta; maxilliped endites separated, narrow, 2.2 L:W, with two slender gustatory cusps and seta on distal margin. Epignath not seen.

Cheliped (Fig. 19A) sclerite large, semitriangular; basis 1.9 L:W, subdistal seta not seen; merus wedge-shape, with ventral seta; carpus 1.2 L:W, with two ventral setae, one subdistal dorsal seta, subproximal seta not seen; chela slender, $1.3 \mathrm{x}$ carpus, $1.5 \mathrm{~L}: \mathrm{W}$; propodus (palm) with one seta near dactylus insertion and eight setae on inner side (one long, seven short); fixed finger as long as wide, with robust distal spine (unguis); incisive margin distally well calcified, with irregular margin, divided by two transversal ridges; three setae on cutting margin and two ventral setae; fixed finger and dactylus unifacial; dactylus almost straight, $3.3 \mathrm{~L}: \mathrm{W}$, with three short spines on cutting margin and subproximal seta on inner side.

Pereopod-1 (Fig. 19B) longer than pereopods 2-3; basis 5.3 L:W, naked; ischium with seta; merus 1.6 L:W, 0.8x carpus, with two short and fine distal spines; carpus $2.7 \mathrm{~L}: \mathrm{W}, 0.7 \mathrm{x}$ propodus, with one short and three longer distal spines; propodus 5.2 L:W, 2.7x dactylus, with one subdistal ventral seta and two subdistal dorsal spines; dactylus 9.0 L:W, $2.7 \mathrm{x}$ unguis, with seta reaching 0.2 of unguis; unguis and dactylus about as long as propodus.

Pereopod-2 (Fig. 19C) coxa with seta; basis 5.4 L:W, naked; ischium with ventral seta; merus $1.8 \mathrm{~L}: \mathrm{W}, 0.8 \mathrm{x}$ carpus, with two small (fine and regular) distal spines; carpus $2.6 \mathrm{~L}: \mathrm{W}, 0.6 \mathrm{x}$ propodus, with one serrate spine and three spines distally; propodus $4.8 \mathrm{~L}: \mathrm{W}$ and $2.4 \mathrm{x}$ dactylus, with subdistal serrate spine ventrally, two subdistal spines (regular and fined) dorsally; dactylus 9.0 L:W, 0.6x unguis, with seta reaching 0.2 unguis; dactylus and unguis as long as propodus.

Pereopod-3 (Fig. 19D) as pereopod-2.

Pereopod-4 (Fig. 19E) basis 2.9 L:W, with two penicillate ventral setae; ischium with two ventral setae; merus 2.3 L:W, as long as carpus, with two serrate spines; carpus $2.4 \mathrm{~L}: \mathrm{W}, 0.8 \mathrm{x}$ propodus, with four distal spines (one longer and serrate), and seta dorsodistally; propodus 8.0 L:W, with two ventrodistal long serrate spines and dorsodistal strongly serrate spine; dactylus $8.0 \mathrm{~L}: \mathrm{W}$; unguis $0.9 \mathrm{x}$ dactylus; together as long as propodus.

Pereopod-5 (Fig. 19F) as pereopod-4, but basis with one penicillate seta.

Pereopod-6 (Fig. 19G) similar to pereopod-5, but propodus with three dorsodistal serrate spines.

Uropod (Fig. $19 \mathrm{H}$ ) basal article 1.4 L:W; exopod with two articles, $0.7 \mathrm{x}$ endopod, article-1 1.8 L:W, with distal seta, article-2 2.7 L:W, with two distal setae; endopod with two articles, article-1 2.1 L:W, with two penicillate distal setae, article-2 1.6 L:W, with five simple and one penicillate setae distally.

Distribution. The species is known only from type locality: Gay Head-Bermuda transect (NW Atlantic) from the depth of $2178 \mathrm{~m}$.

Remarks. Paranarthrurella moonwalk sp. nov. is one of two species with a short body habitus and large hyposphaenium on pleonite-3 and a small hyposphaenium on pleonite-2. Another species with likewise distributed hyposphaenia is the Australian P. corroboree (see remarks above). Two other species present in the North Atlantic are $P$. voeringi and $P$. arctophylax (see remarks in relevant sections).

Paranarthrurella polonez Błażewicz and Jóźwiak, sp. nov.

Figures 20-23

Material examined. Holotype: neuter (4.6 mm BL) (ZMH K-55988), (ind. 279), RV Sonne (SO-239), St. 95 (IOM).

Paratypes: manca-2 (3.5 mm BL) (ZMH K-55989), (ind. 280), the same locality as holotype; neuter (length $4.3 \mathrm{~mm} \mathrm{BL}$ ) (ZMH K-55992), (ind. 171), manca-3 (3.6 mm BL) (ZMH K-55990), (ind. 173), one neuter (3.0 mm BL) (ZMH K-55991), (ind. 170), neuter (ind 169, lost), RV Sonne (SO-239), St. 81 (IOM); female (4.8 mm BL) (ZMH K-55994), (ind. 298), juvenile male(?) (2.9 mm BL) (ZMH K-55995), (ind. 299), RV Sonne (SO-239), St. 99 (IOM); neuter (4.8 mm BL, dissected) (ZMH K-55993). (ind. 266), RV Sonne (SO-239), St. 106 (IOM).

Diagnosis. Female. Body long (>8 L:W). Pereonite-1 $0.8 \mathrm{~L}: \mathrm{W}$. Pleonites lateral margin pointed. Pleonites 2-4 without hyposphaenia. Pleon rounded and swollen, apex small. Cheliped carpus 1.6 L:W. Pereopod-1 merus with fine spine. Pereopods 4-6 carpus with four spines. Pereopods 4-6 propodus dorsodistal spine finely serrate. Uropod endopod 1.1x exopod.

Etymology. The species name is given for a dance of Polish origin. Noun in apposition.

Description of neuter, length $4.3 \mathrm{~mm}$. Body (Fig. 21A,B) slender, 7.7 L:W; cephalothorax 1.3 L:W, 2.3x pereonite-1. Pereonites $1-6: 0.8,1.2,1.1,1.1,1.2$ and $0.6 \mathrm{~L}: \mathrm{W}$, respectively; pereonites $2-5$ subsquare, pereonites $1-3$ wider proximally, pereonites $4-5$ wider in midlength. Pleon (Fig. 21C) 0.2 of total body length. All pleonites the same size, $0.3 \mathrm{~L}: \mathrm{W}$. Pleotelson $2.5 \mathrm{x}$ pleonite-5, rounded; apex small directed downward.

Antennule (Fig. 22A) article-1 3.0 L:W, 2.5x article-2, with small distal seta; article-2 1.6 L:W, 1.8x article-3, with simple and penicillate distal setae; article-3 1.95 L:W, 0.6x article-4, with long, short and penicillate setae distally; article-4 4.75 L:W; article-5 minute, partly fused with article-4, with at least two long and one short distal setae and aesthetasc. 


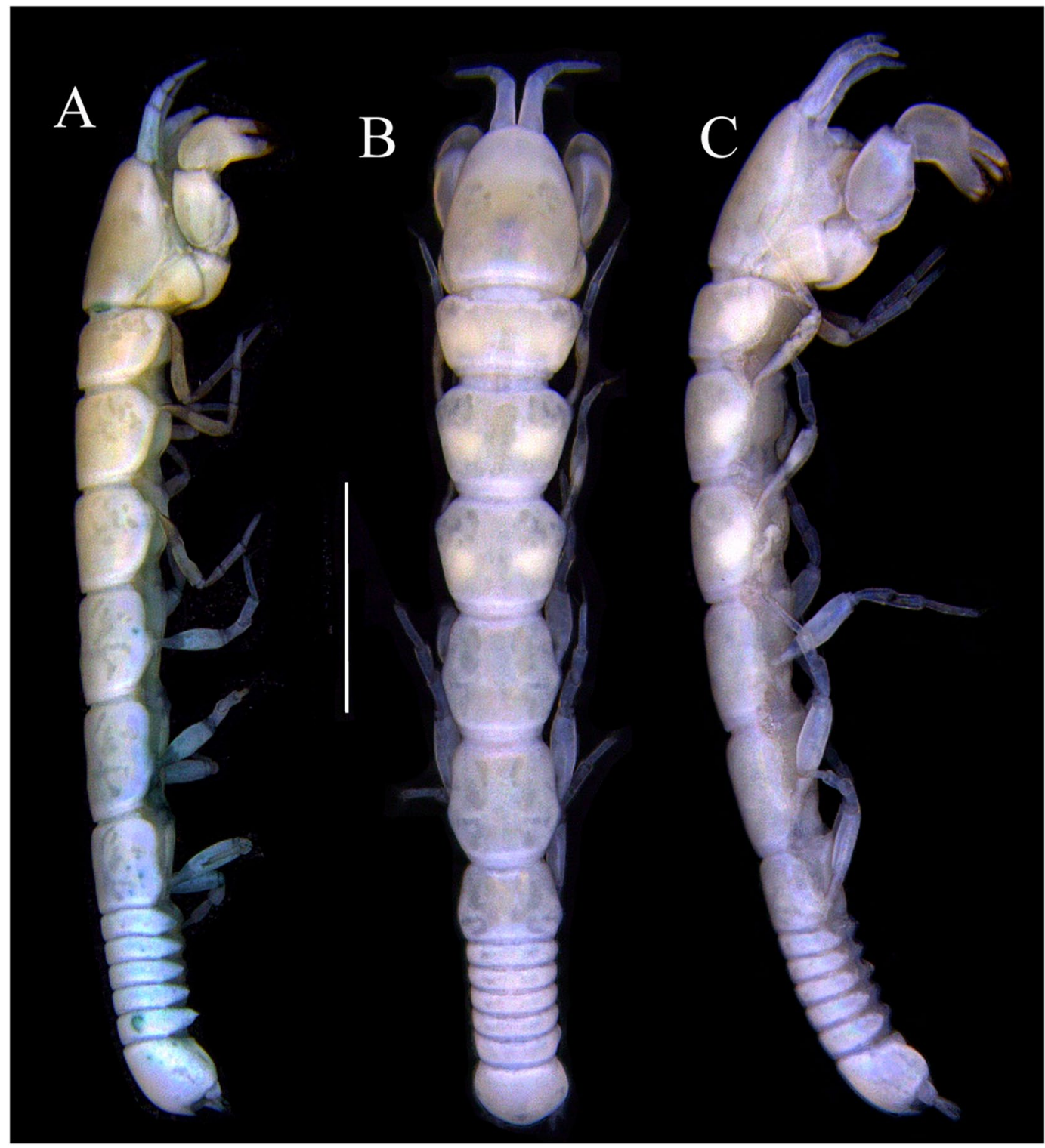

Figure 20. Paranarthrurella polonez sp. nov. (A) neuter, dorsal (ind. 169, lost). (B,C) Holotype neuter, dorsal and lateral (ZMH K-55988). Scale $1 \mathrm{~mm}$.

Antenna (Fig. 22B) 0.7 times length of antennule; article-1 fused with body; article-2 $2.5 \mathrm{~L}: \mathrm{W}, 1.5 \mathrm{x}$ article-3, with distodorsal seta, set at right angle to axis of the article; article-3 $1.25 \mathrm{~L}: \mathrm{W}, 0.3 \mathrm{x}$ article-4, with distodorsal seta, situated in right angle to axis of the article; article- $45.8 \mathrm{~L}: \mathrm{W}, 1.5 \mathrm{x}$ article-5, with three simple and three penicillate distal setae; article-5 4.1 L:W, with distal seta; article-6 as long as wide, with four long and two short distal setae.

Mouthparts. Labrum (Fig. 22C) large, elongate, distally obtuse and with dense and robust setae. Right mandible (Fig. 22E) incisor upper edge simple; lacinia mobilis fused with incisor, prominent, edge simple; molar lobeform, distally weakly rounded, with nine weak, finger-shape setae. Left mandible (Fig. 22D) incisor with three rounded projections subdistally and two distally separated by short gap; lacinia mobilis well developed, narrow little longer than incisor; molar with five weak, finger-shape setae. Maxillule endite (Fig. 22F)with ten strong distal spines of various length and numerous setae along inner and outer margin; palp (Fig. 22F') with two long simple setae. Maxilla (Fig. 22G) semi-triangular, simple. Labium (Fig. 22H) with two lobes; inner lobe with numerous spines on inner margin and with strong setae distally; outer lobe bilobed smaller than inner lobe, with simple margin. Maxilliped (Fig. 22I) basis 1.3 L:W, with long seta overeaching endites; palp article-1 1.1 L:W, naked; article-2 1.2 L:W, with three inner setae (one very long) and outer seta; article-3 1.5 L:W, with four inner setae (three sparsely serrate); article-4 2.7 L:W, with distal and subdistal inner setae (one sparsely setose, four serrate), and outer seta; maxilliped endites separated, narrow, $2.2 \mathrm{~L}: \mathrm{W}$, distally with two slender gustatory cusps. Epignath (Fig. 2J) distally narrowed and pointed.

Cheliped (Fig. 23A) sclerite large semitriangular; basis 1.3 L:W, with subdistal dorsal seta; merus wedge-shape, with ventral seta (broken); carpus 1.7 L:W, with two ventral setae, one subdistal and one subproximal dorsal setae; 

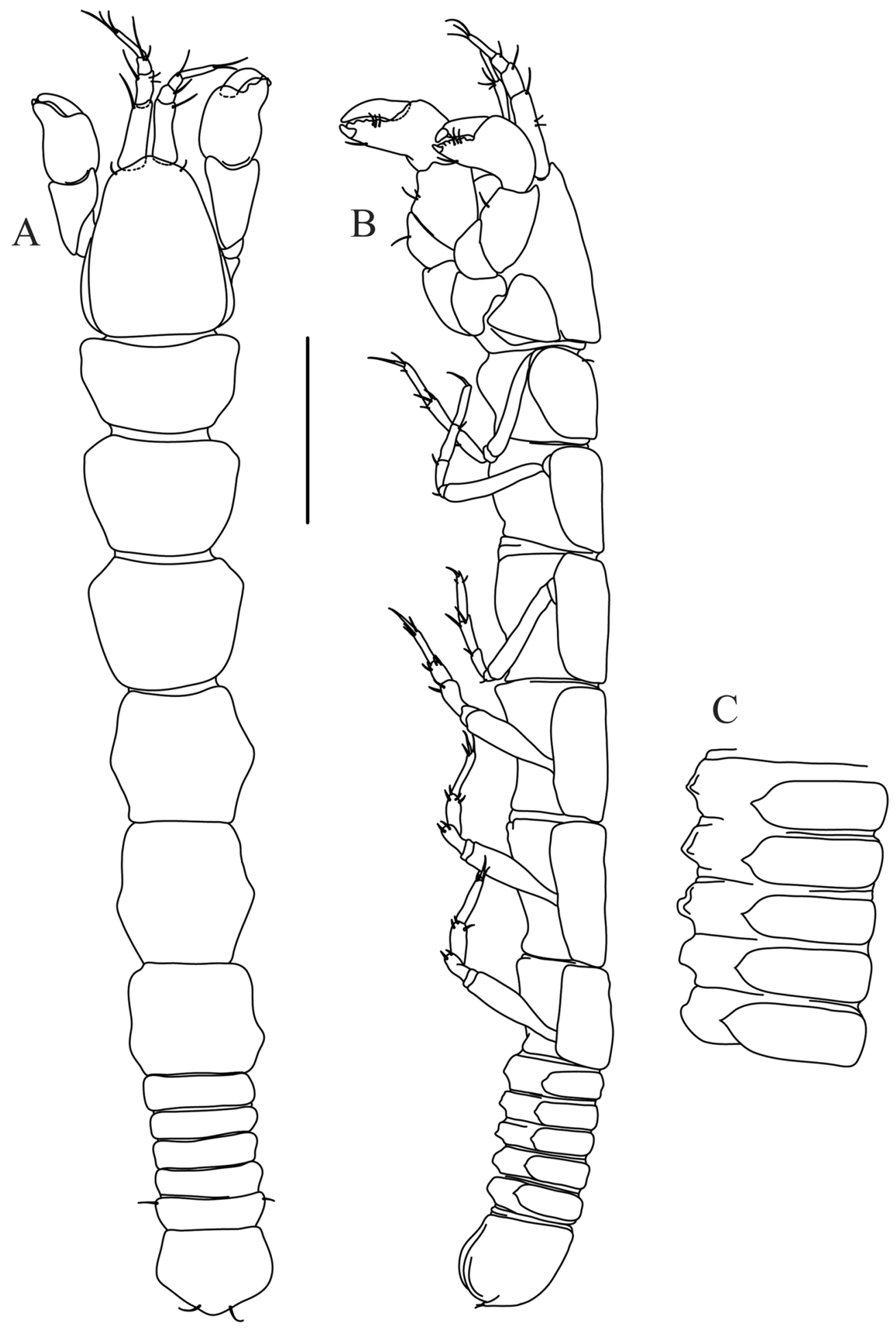

Figure 21. Paranarthrurella polonez sp. nov. Neuter (ind. 169, lost) (A) Dorsal. (B) Lateral. (C) pleon lateral. Scale $1 \mathrm{~mm}$.

chela slender, 1.2x carpus, 1.7 L:W; propodus (palm) with one seta near dactylus insertion and five setae on inner side; fixed finger with robust distal spine; incisive margin distally well calcified, edge irregular, with two transversal grooves and with small tooth in midlength; three setae on cutting margin and two ventral setae; fixed finger and dactylus unifacial; dactylus almost straight with three short spines on cutting margin, subproximal seta on inner side not seen.

Pereopod-1 (Fig. 23B) longer than pereopods 2-3; basis $5.5 \mathrm{~L}: \mathrm{W}$, naked; ischium with seta; merus $2.5 \mathrm{~L}: \mathrm{W}$, $0.55 \mathrm{x}$ carpus, with ventrodistal fine spine; carpus $4.4 \mathrm{~L}: \mathrm{W}$, subequal to propodus, with four distal spines (one short and three long); propodus 6.1 L:W, 3.0x dactylus, with one short ventrodistal spine, two dorsodistal spines 


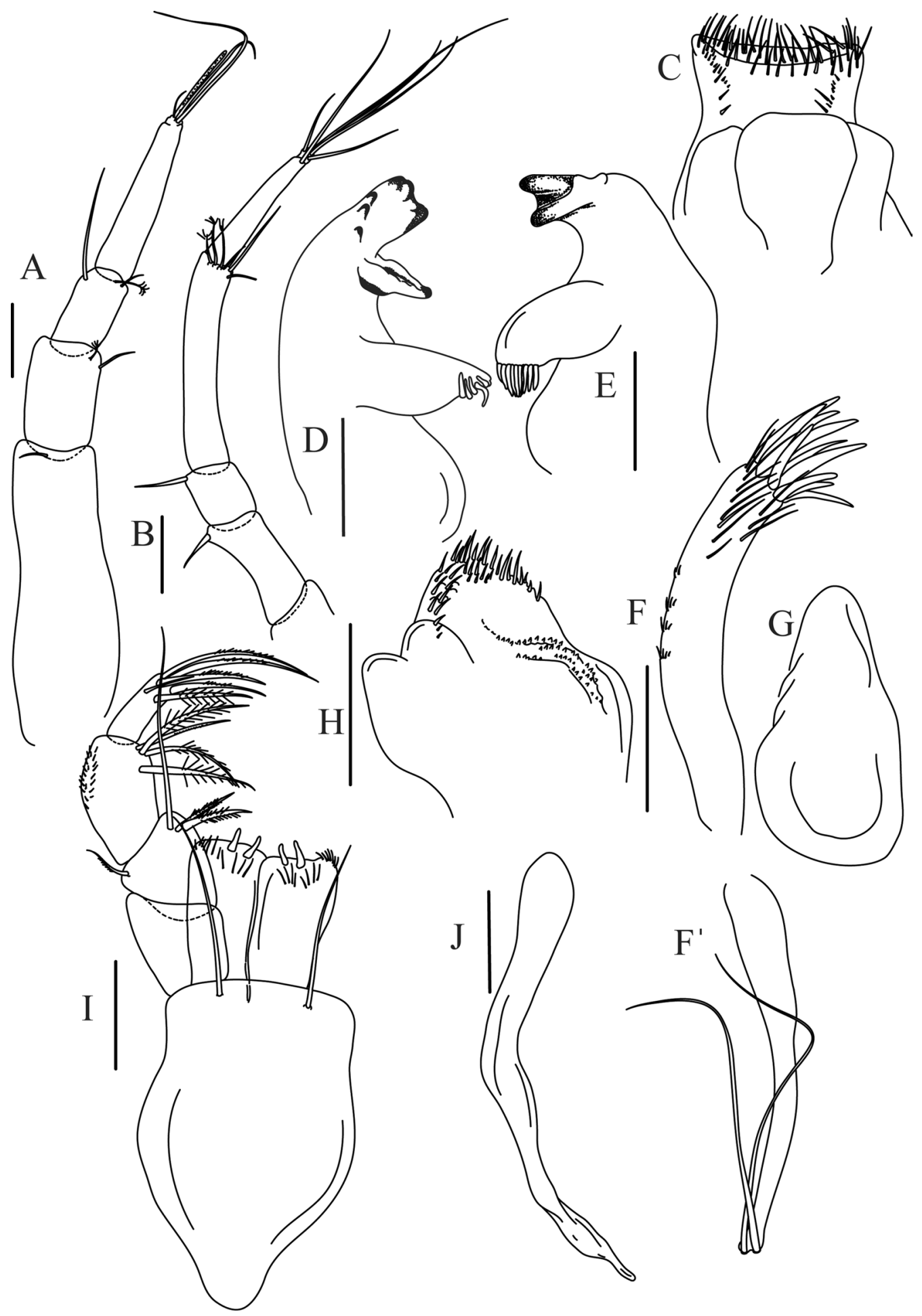

Figure 22. Paranarthrurella polonez sp. nov. paratype, neuter (ZMH K-55993) (A) Antennule. (B) Antenna. (C) labrum. (D) Mandible, left. (E) Mandible right. (F) Maxillule, endite; (F') Maxillule, palp. (G) Maxilla. (H) Labium. (I) Maxilliped. (J) Epignath. Scale $0.1 \mathrm{~mm}$.

(fine and longer serrate); dactylus $0.7 \mathrm{x}$ unguis, with seta reaching 0.2 of unguis; unguis and dactylus about $0.7 \mathrm{x}$ propodus.

Pereopod-2 (Fig. 23C) basis 5.0 L:W, with subproximal dorsal seta; ischium with ventral seta; merus $2.9 \mathrm{~L}: \mathrm{W}$, $0.6 \mathrm{x}$ carpus, with two ventrodistal fine and regular spines; carpus $3.75 \mathrm{~L}: \mathrm{W}, 0.9 \mathrm{x}$ propodus, with four distal serrate spines; propodus 5.25 L:W and 3.0x dactylus, with subdistal ventral short spine and dorsodistal fine and serrate 


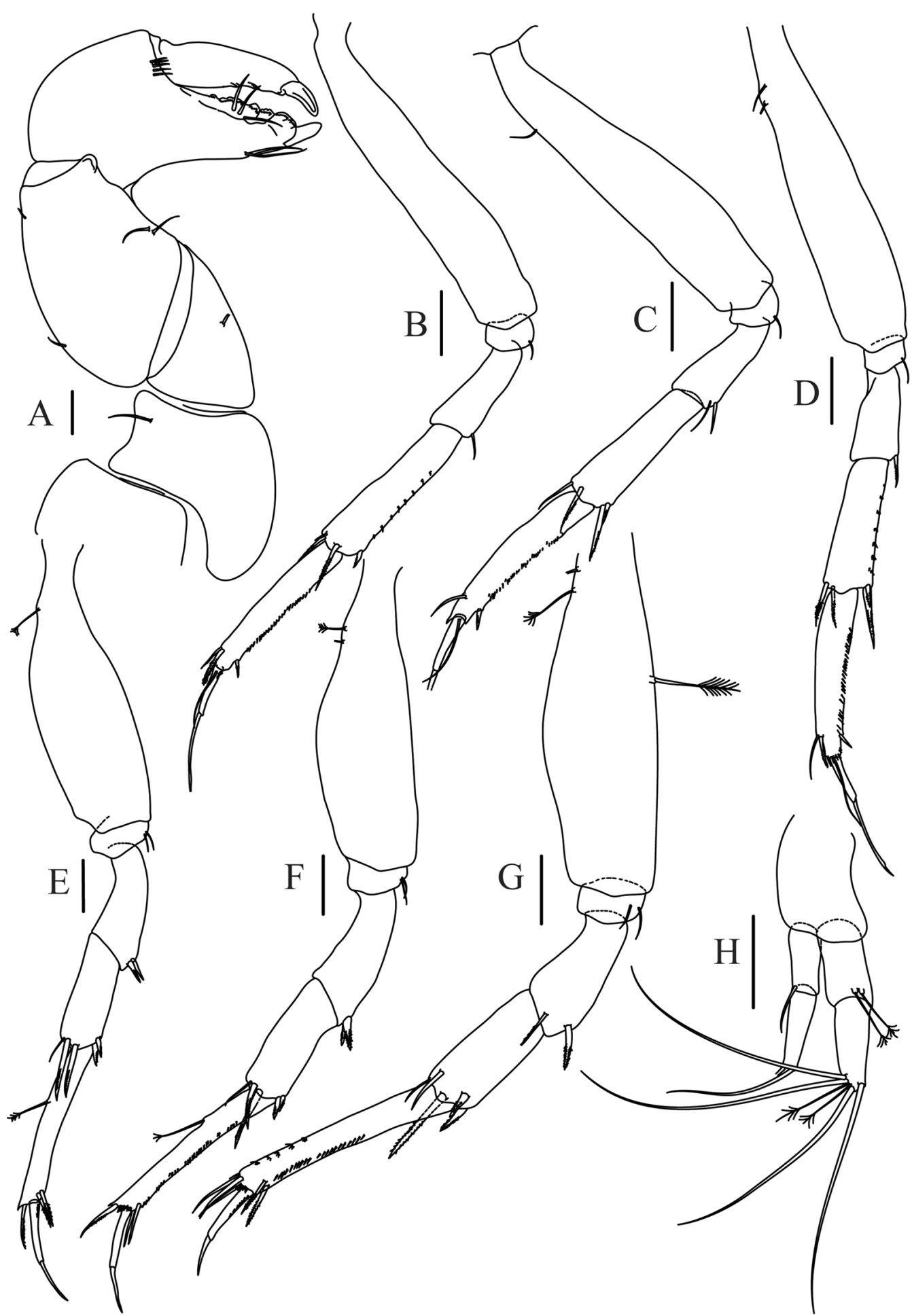

Figure 23. Paranarthrurella polonez sp. nov., paratype, neuter (ZMH K-55993) (A) Cheliped. (B-G) Pereopod $1-6$, respectively. (H) Uropod. Scale $0.1 \mathrm{~mm}$.

spine (seta broken), ventral margin with microtrichia; dactylus 7.0 L:W, with seta reaching over proximal part of unguis; unguis broken.

Pereopod-3 (Fig. 23D) similar to pereopod-2, but basis with two subproximal penicillate setae (one broken); unguis almost twice as long as dactylus, together $0.8 \mathrm{x}$ propodus.

Pereopod-4 (Fig. 23E) basis 3.1 L:W, with subproximal distal penicillate seta; ischium with two ventral setae; merus 2.6 L:W, as long as carpus, with two ventrodistal serrate spines; carpus $2.9 \mathrm{~L}: \mathrm{W}, 0.6 \mathrm{x}$ propodus, with four distal spines and one rod-like seta; propodus 7.3 L:W, with penicillate middorsal seta, two ventrodistal serrate spines and one serrate dorsodistal spine; dactylus 9.6 L:W; unguis $0.7 \mathrm{x}$ dactylus; together $0.7 \mathrm{x}$ propodus. 


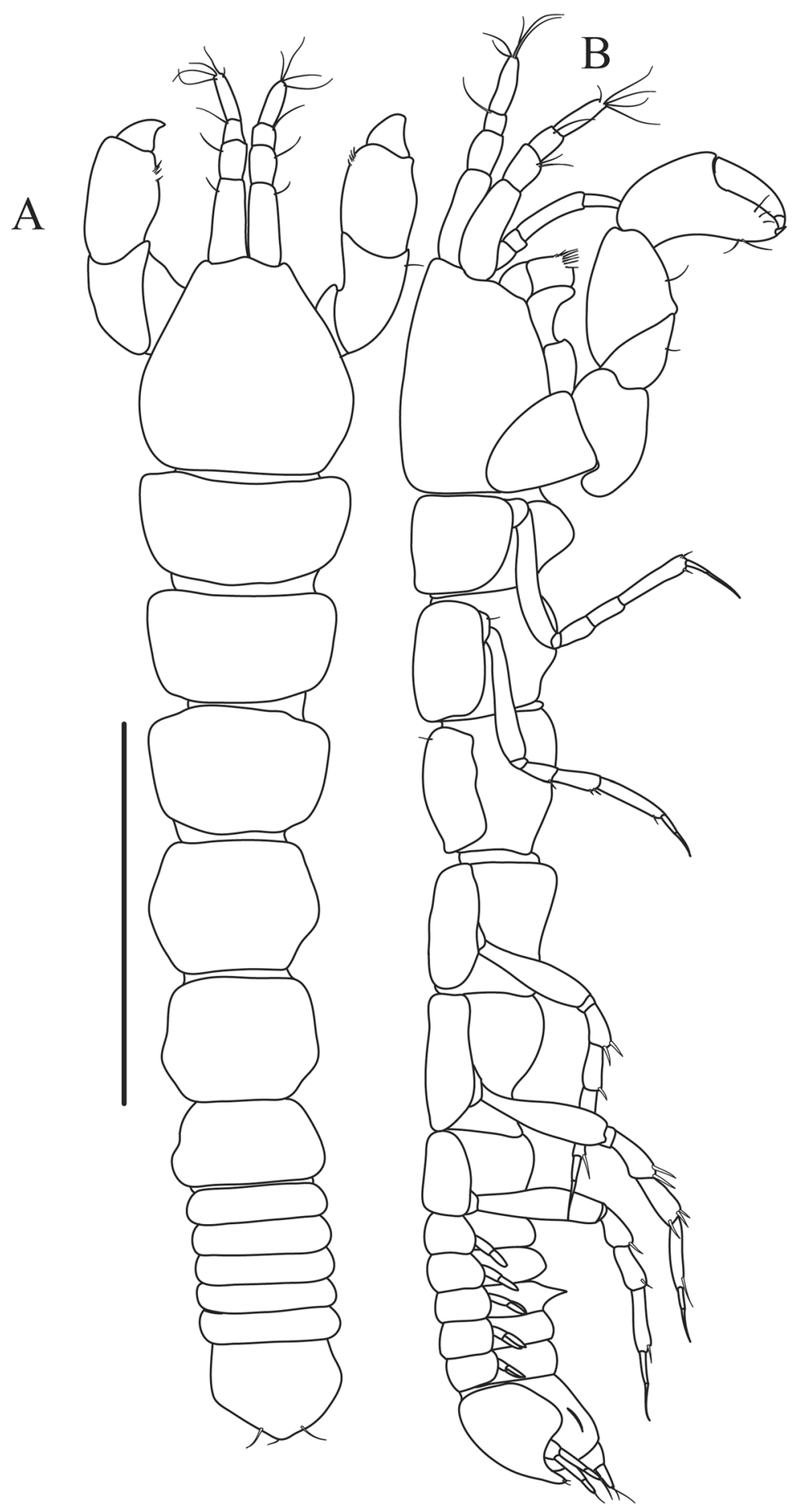

Figure 24. Paranarthrurella rocknroll sp. nov. holotype, neuter (MCZ:IZ:48498) (A) dorsal; (B) lateral. Scale $1 \mathrm{~mm}$.

Pereopod-5 (Fig. 23F) similar to pereopod-4, but basis with two penicillate setae.

Pereopod-6 (Fig. 23G) similar to pereopod-5, but basis with two subproximal dorsal and one midventral penicillate setae; propodus without dorsodistal penicillate seta and with three dorsodistal serrate spines.

Uropod (Fig. 23H) basal article 1.6 L:W; exopod with two articles, 0.9x endopod, article-1 2.5 L:W, with distal seta, article-2 3.5 L:W, with two distal setae; endopod with two articles, article-1 1.95 L:W, with two penicillate distal setae; article-2 2.65 L:W, with four simple and two penicillate setae distally.

Distribution. The species occurs in Clarion Clipperton Zone, in Interoceanmetal claim area (IOM), at the depth 4365-4823 m.

Remarks. Paranarthrurella polonez sp. nov. can be distinguished from all other congeners by the pointed lateral margins of the pleonites. It is one of two Paranarthrurella species occurring in the Central Pacific in the area 


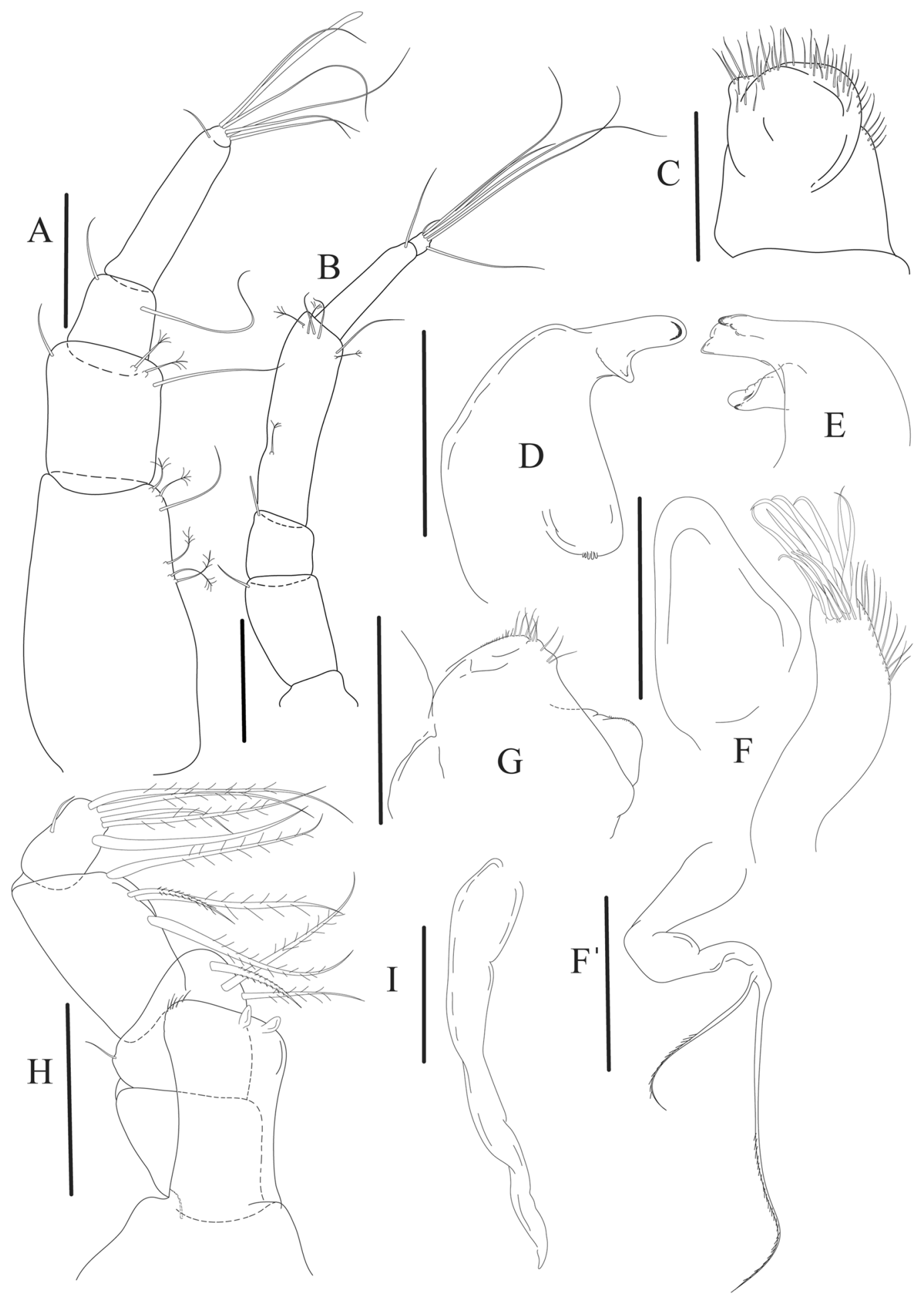

Figure 25. Paranarthrurella rocknroll sp. nov., holotype, neuter (MCZ:IZ:48498) (A) Antennule. (B) Antenna. (C) Labrum. (D) Mandible, right. (E) Mandible, left. (F) Maxillula and maxilla. (F') Maxillula, palp.

(H) Maxilliped. (I) Epignath. Scale $0.1 \mathrm{~mm}$.

associated with manganese nodules. Paranarthrurella spinimaxillipeda has smooth margins of the pleonites, but also the exopod uropod clearly shorter than the endopod, while the uropod exopod is only a little shorter than the endopod in P. polonez. 


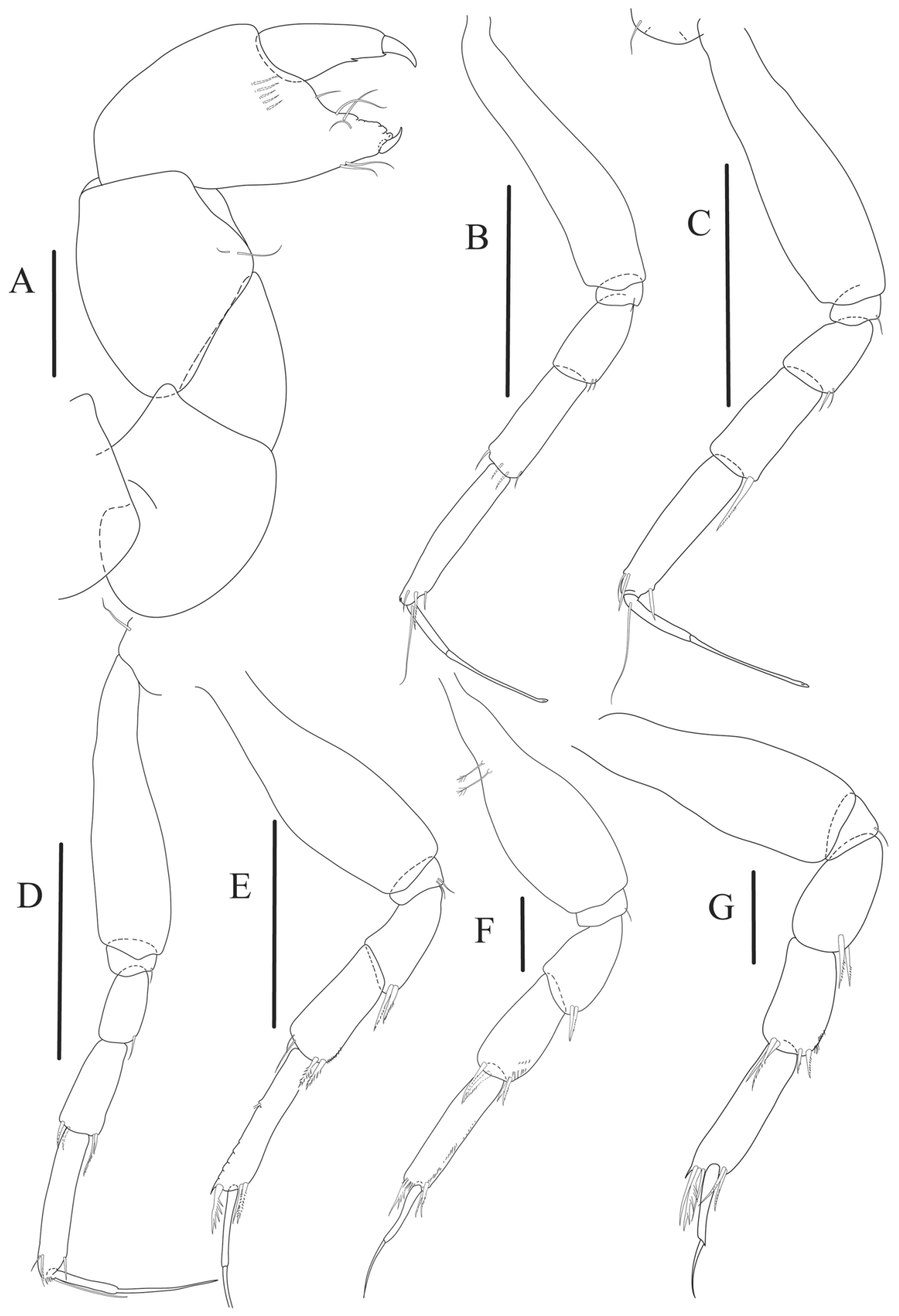

Figure 26. Paranarthrurella rocknroll sp. nov., holotype, neuter (MCZ:IZ:48498) (A) Cheliped. (B-G) Pereopod $1-6$, respectively. Scale $0.1 \mathrm{~mm}$.

\section{Paranarthrurella rocknroll Błażewicz and Jóźwiak sp. nov.}

Figures 16 and 24-26

Material examined. Holotype, neuter, (3.27 mm BL, partly dissected), (MCZ:IZ:48498), RV Atlantis II, Cr. 24, St. 120.

Diagnosis. Female. Body short (<6.5 L:W). Pereonite-1 0.5 L:W. Pleonites lateral margin smooth. Pleonite 2 and 4 without hyposphaenium; pleonite- 3 with small hyposphaenium. Pleon rounded and swollen, apex 
small. Cheliped carpus 1.3 L:W. Pereopod-1 merus with two small setae. Pereopods 4-6 carpus with four spines. Pereopods 4-6 propodus dorsodistal spine strongly serrate. Uropod endopod 1.5x exopod.

Etymology. The species name is given for a genre of dance originated and evolved in the United States of America. Noun in apposition.

Description of neuter, length $3.27 \mathrm{~mm}$. Body (Figs 16 and 24A,B) robust, $6.0 \mathrm{~L}: \mathrm{W}$; cephalothorax 1.1 L:W, $2.2 \mathrm{x}$ pereonite-1. All pereonites wider than long. Pereonites $1-6: 0.5,0.6,0.7,0.7,0.7$ and $0.6 \mathrm{~L}: \mathrm{W}$, respectively. All pereonites wider than long; pereonites 1-3 wider proximally, pereonites $4-5$ wider in midlength. Pleon 0.25 of total body length. All pleonites the same size, $1.8 \mathrm{~W}: \mathrm{L}$. Pleonite- 3 with small pointed triangular hyposphaenium. Pleotelson 4.0x pleonite-5.

Antennule (Fig. 25A) article-1 1.9 L:W, 2.1x article-2, with three penicillate setae at midlength, one simple and two penicillate setae distally; article-2 1.3 L:W, 1.6x article-3, with two simple and two penicillate setae distally; article-3 1.3 L:W, 0.6x article-4, with two long setae distally; article-4 4.0 L:W; article-5 almost completely fused with article-4, with five long and one short setae, and with aesthetasc distally.

Antenna (Fig. 25B) 0.8 times length of antennule; article-1 fused with body; article-2 1.5 L:W, 1.5x article-3, with distodorsal seta; article-3 1.1 L:W, 0.3x article-4, with distodorsal seta; article-4 3.6 L:W, 1.7x article-5, with penicillate seta at midlength, three simple and three penicillate setae distally; article-5 4.2 L:W, with distal seta; article- 6 minute, with four long and two short distal setae.

Mouthparts. Labrum (Fig. 25C) hood-shape, distally setose. Left mandible (Fig. 25E) incisor distally cut, undulate, lacinia mobilis margins undulate; molar process not seen. Right mandible (Fig. 25D) incisor margin simple, distally rounded, lacinia mobilis in shape of small protrusion; molar process broad and rounded distally, with row of minute finger-shape spines. Maxillule endite (Fig. 25F) with ten, relatively long and slender spines, distal and dorsodistal margin setulose; palp (Fig. 25F') with two distal serrate setae. Maxilla (Fig. 25F) triangular, naked. Labium (Fig. 25G) bilobed; inner lobe with numerous, short setae along distal margin; outer lobe, vestigial, simple. Maxilliped (Fig. 25H) basis partly broken during dissection, with minute distal seta; palp article-1 as long as wide, naked; article-2 as long as wide, with three inner setae and one outer seta; article-3 1.4 L:W, with four inner setae; article-4 1.7 L:W, with five serrate setae distally and one simple subdistal seta; maxilliped endites separate, with a pair of slender gustatory cusps, distouter corner setulate. Epignath (Fig. 25I) distally pointed, naked.

Cheliped (Fig. 26A) sclerite large triangular; basis 1.6 L:W; merus ventral margin longer than that of carpus, ventral seta not seen; carpus wider medially, 1.4 L:W, with two ventral setae, dorsal setae not seen; chela $1.3 \mathrm{x}$ carpus, propodus (palm) with one longer and four short setae on inner side and seta near dactylus insertion; fixed finger with two simple setae ventrally and three setae on cutting edge, incisive margin well calcified, with uneven blunt teeth; fixed finger and dactylus unifacial; dactylus weakly bent downward, with weak spines on cutting margin.

Pereopod-1 (Fig. 26B) basis 5.0 L:W, naked; ischium with ventral seta; merus $2.0 \mathrm{~L}: \mathrm{W}, 0.8 \mathrm{x}$ carpus, with two weak ventrodistal spines; carpus $2.9 \mathrm{~L}: \mathrm{W}, 0.8 \mathrm{x}$ propodus, with four fine spines distally; propodus $4.7 \mathrm{~L}: \mathrm{W}, 2.5 \mathrm{x}$ dactylus, with small ventral spine and two unequal fine dorsal spines distally; dactylus 0.6x unguis, with proximal seta; unguis and dactylus about $1.1 \mathrm{x}$ propodus.

Pereopod-2 (Fig. 26C) coxa with seta; basis 3.6 L:W, naked; ischium with ventral seta; merus 1.2 L:W, with two ventrodistal spines (slender and robust); carpus $2.3 \mathrm{~L}: \mathrm{W}, 0.7 \mathrm{x}$ propodus, with long and short ventrodistal spine; propodus $3.8 \mathrm{~L}: \mathrm{W}$ and $2.3 \mathrm{x}$ dactylus, with fine and strong subdistal dorsal spines and ventrodistal spine; dactylus $0.6 \mathrm{x}$ unguis, with one proximal seta; dactylus and unguis $1.2 \mathrm{x}$ propodus.

Pereopod-3 (Fig. 26D) as pereopod-2, but only one spine on merus, and four distal spines on carpus observed (three short one longer).

Pereopod-4 (Fig. 26E) basis3.0 L:W; ischium with two ventral setae; merus 2.0 L:W, 0.9x carpus, with two ventrodistal serrate spines; carpus $2.3 \mathrm{~L}: \mathrm{W}, 0.7 \mathrm{x}$ propodus, with two simple, fine dorsodistal spines and two ventrodistal serrate spines; propodus 7.0 L:W, with one penicillate dorsal seta (broken), two ventrodistal serrate spines and strongly serrate dorsodistal spine; unguis broken.

Pereopod-5 (Fig. 26F) similar to pereopod-4, but basis with two penicillate dorsal setae, dactylus 1.1x unguis; dactylus and unguis $0.9 x$ propodus.

Pereopod-6 (Fig. 26G) similar to pereopod-5, but basis naked, propodus with two ventrodistal spines and three dorsodistal spines (one strongly serrate).

Uropod (not illustrated) basal article about 1.5 L:W; exopod with two articles, about $0.5 \mathrm{x}$ endopod, article-1 about $2.2 \mathrm{~L}: \mathrm{W}$, article-2 about $2.5 \mathrm{~L}: \mathrm{W}$, with at least two distal setae; endopod with two articles, article-1 about 2.0 $\mathrm{L}: \mathrm{W}$; article-2 about $2.5 \mathrm{~L}: \mathrm{W}$, with four simple distal setae.

Distribution. Species known only from the type locality, Gay Head-Bermuda transect, between 5018 and 5023 m depth.

Remarks. Paranarthrurella rocknroll sp. nov. is the second species with a short body and hyposphaenium present only on pleonite-3. The hyposphaenium is small and pointed downward distinguishing it from P. arctophylax occurring in the North Atlantic; it has hyposphaenium large and weakly pointed backward ${ }^{80}$.

Paranarthrurella samba Błażewicz and Jóźwiak sp. nov.

Figures 27-32

Material examined. Holotype: neuter (4.5 mm BL), (MCZ:IZ:49400), RV Atlantis II, Cr. 31, St. 156. 


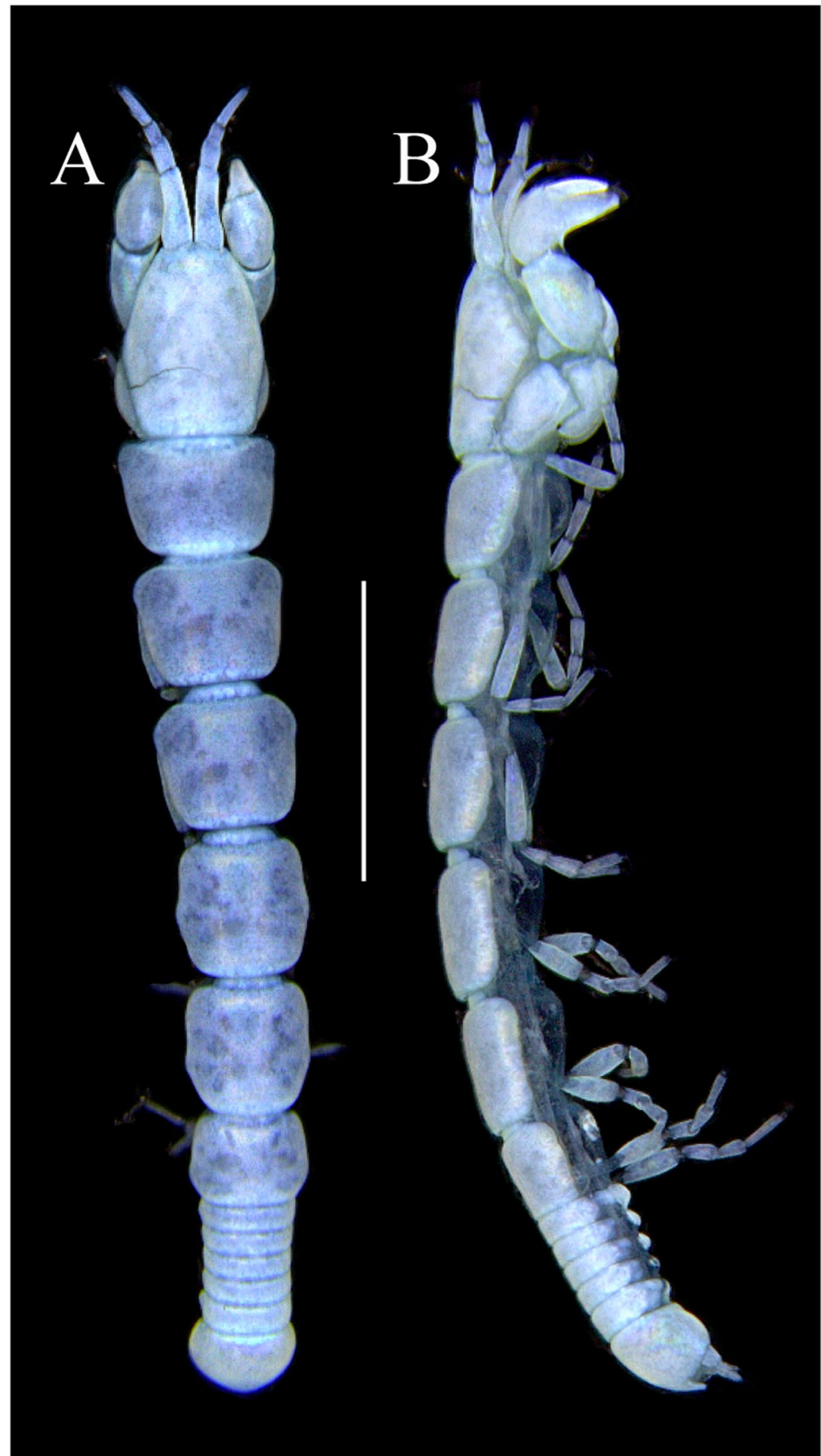

Figure 27. Paranarthrurella samba sp. nov. (A,B) holotype, neuter (MCZ:IZ:49400). Scale $1 \mathrm{~mm}$.

Paratypes. $\quad$ Male, partly dissected, $3.4 \mathrm{~mm}$ BL (MCZ:IZ:149578); neuter, dissected (MCZ:IZ:149579); three juvenile males, $2.7-3.3 \mathrm{~mm} \mathrm{BL}$, neuter, $3.6 \mathrm{~mm} \mathrm{BL}$, two mancas-2, 2.0-2.6 mm BL, five mancas-2, 1.4-2.5 mm BL (MCZ:IZ:149580); two females, 3.5-4.1 mm BL, male, 5.0 mm BL, two mancas 2.5-2.5 mm BL (MCZ:IZ:149581), the same locality as holotype.

Diagnosis. Female. Body long (>8.0 L:W). Pereonite-1 0.8 as long as wide. Pleonites lateral margin smooth. Pleonites 2-4 without hyposphaenium. Pleon round, apex small pointed downward. Cheliped carpus 1.6 L:W. Pereopod-1 merus with one fine spine. Pereopods 4-6 carpus with four spines. Pereopods 4-6 propodus dorsodistal spine finely serrate. Uropod endopod $1.4 \mathrm{x}$ exopod. 


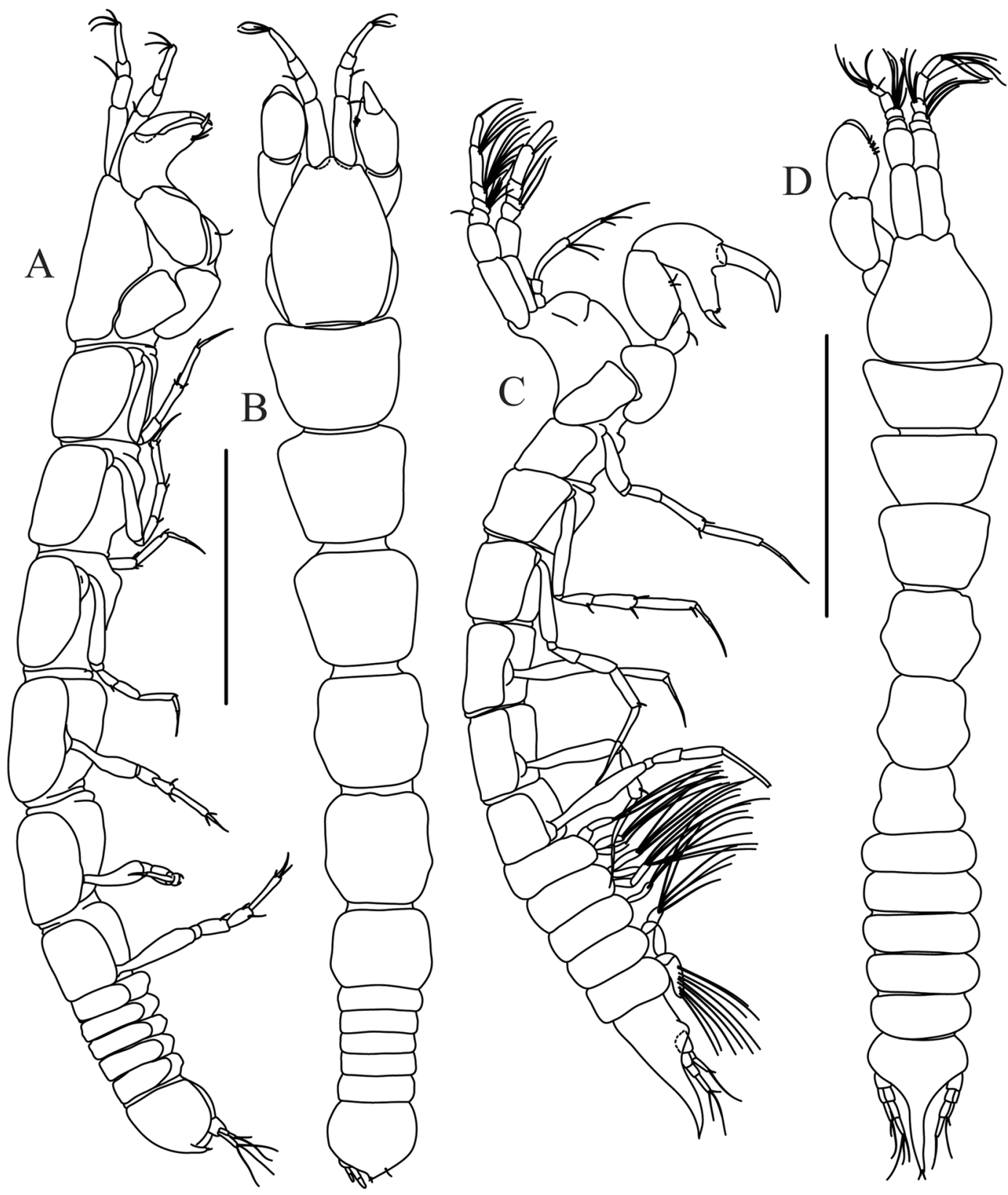

Figure 28. Paranarthrurella samba sp. nov. holotype, neuter (MCZ:IZ:49400) (A) lateral and (B) dorsal. Male (MCZ:IZ:149578) (C) lateral and (D) dorsal, respectively. Scale $1 \mathrm{~mm}$.

Etymology. The species that was found off Brazilian coast is called after a samba - Brazilian musical genre and dance style. Noun in apposition.

Description of neuter, length $4.5 \mathrm{~mm}$. Body (Fig. 28A,B) slender, nine L:W; cephalothorax 1.4 L:W, 1.7x pereonite-1. Pereonites $1-6: 0.8,0.9,1.0,1.0,1.1$ and $0.75 \mathrm{~L}: \mathrm{W}$, respectively; pereonites $2-5$ subsquare, pereonites 1-3 wider proximally, pereonite slightly wider in midlenght. Pleon 0.2 of total body length. All pleonites the same size, 0.3 L:W. Pleotelson 3.0x pleonite-5.

Antennule (Fig. 29A) article-1 3.6 L:W, 2.2x article-2, with eight penicillate and one simple setae subdistally; article-2 1.9 L:W, 1.5x article-3, with one simple and four penicillate setae subdistally; article-3 1.7 L:W, 0.5x article-4, with distal seta; article-4 4.3 L:W; article-5 vestigial semifused with article-4, with five simple and one penicillate setae distally; aesthetasc not observed.

Antenna (Fig. 29B) 0.7 times length of antennule; article-1 fused with body; article-2 2.3 L:W, 1.3x article-3, with distodorsal seta, situated in right angle to axis of the article; article-3 1.7 L:W, $0.3 \mathrm{x}$ article-4, with distodorsal seta; article-4 7.3 L:W, 2.4x article-5, with one simple and three penicillate setae distally; article-5 1.9 L:W, with long distal seta; article- 6 as long as wide, with four long and two short distal setae.

Mouthparts. Labrum (Fig. 29C) large, distally obtuse and densely setose. Right mandible (Fig. 29E) incisor upper edge weakly undulate, with blunt proximal process, lacinia mobilis relatively small and rounded; molar lobeform, distally acuminate, with six to seven weak, finger-shape setae. Left mandible (Fig. 29D) incisor 


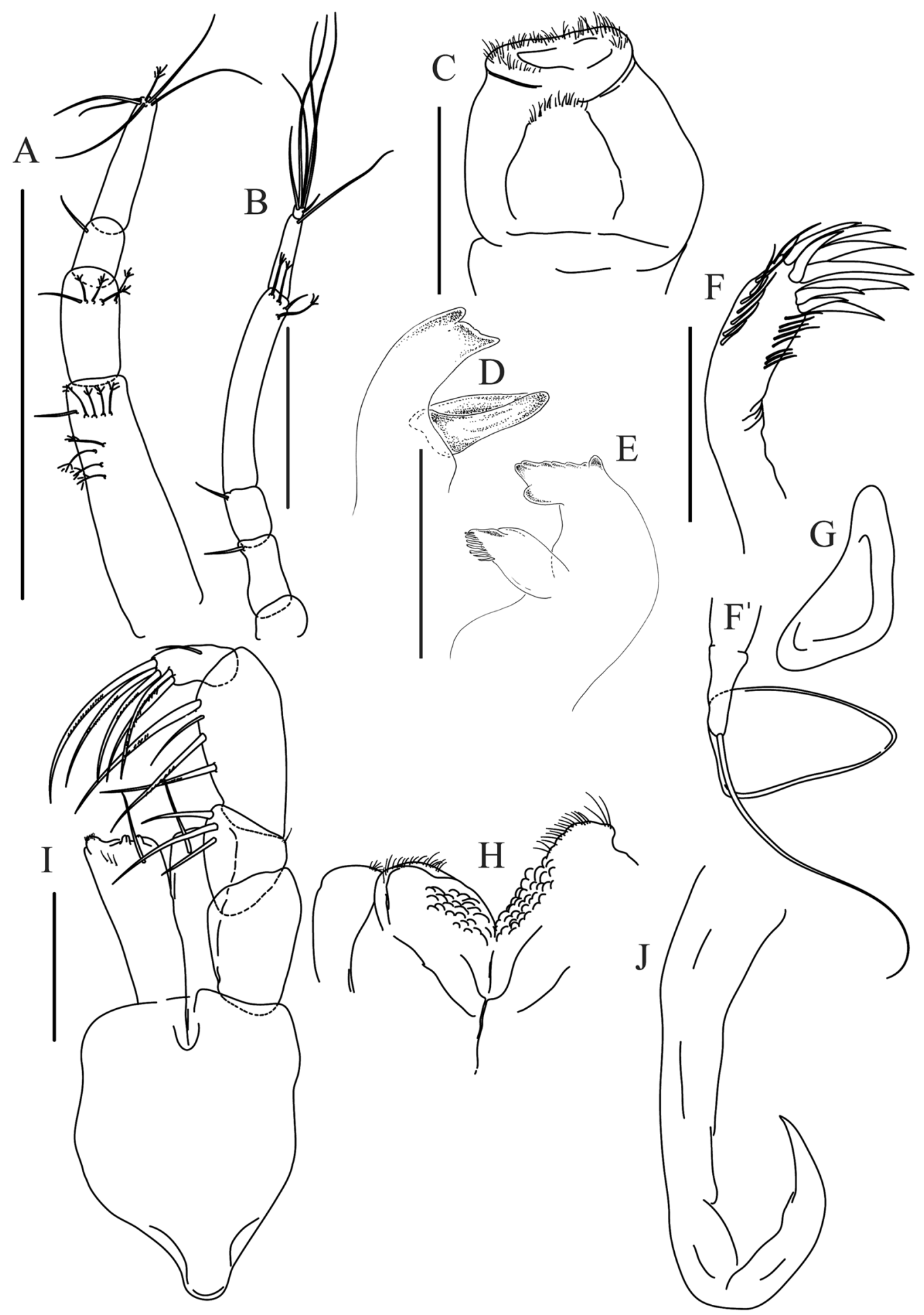

Figure 29. Paranarthrurella samba sp. nov., paratype, neuter (MCZ:IZ:149579) (A) Antennule. (B) Antenna. (C) Labrum. (D) Mandible, left. (E) Mandible, right. (F) Maxillule. (F') Maxillule endite. (G) Maxilla. (H) Labium. (I) Maxilliped. (J) Epignath. Scale $0.1 \mathrm{~mm}$.

narrower than in right mandible, distally obtuse and weakly undulate, with distal and proximal spines; lacinia mobilis well developed, little longer than incisor, edge simple. Maxillule endite (Fig. 29F) with nine strong distal spines of various length and numerous setae along inner and outer margin; palp (Fig. 29F') with two long simple setae. Maxilla (Fig. 29G) semitriangular. Labium (Fig. 29H) with two lobes; inner lobe with numerous crenulations at inner margin and densely setose distally; outer lobe little smaller than inner lobe, margin simple. Maxilliped (Fig. 29I) basis 1.3 L:W, naked; palp article-1 1.6 L:W, naked; article-2 1.2 L:W, with three inner and one outer setae; article-3 2.1 L:W, with four inner setae (three long, one short); article-4 $2.25 \mathrm{~L}: \mathrm{W}$, with five distal 


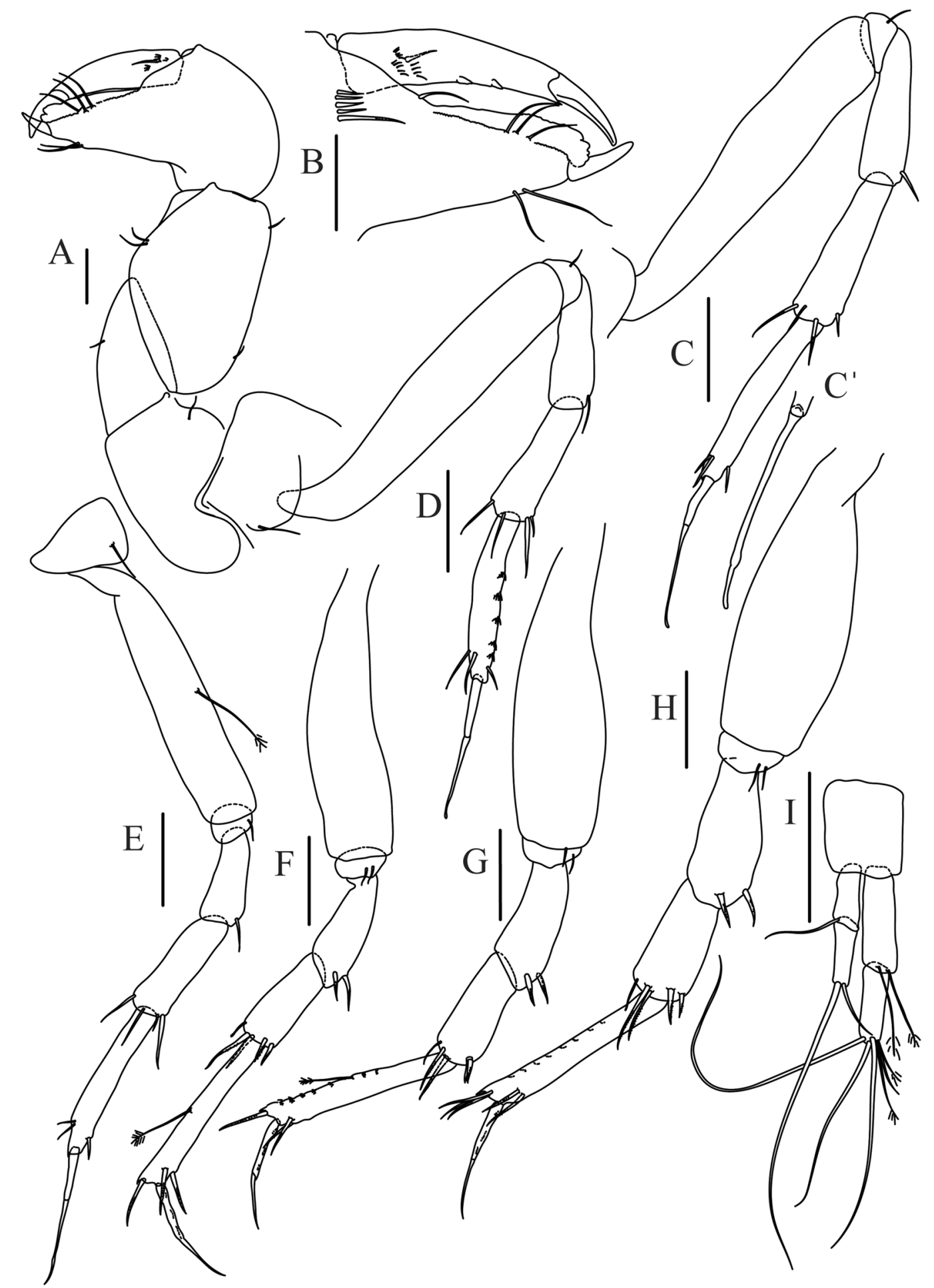

Figure 30. Paranarthrurella samba sp. nov., paratype, neuter (MCZ:IZ:149579) (A) Cheliped. (B) Chela inner side. (C-H) Pereopod 1-6, respectively. (I) Uropod. Scale $0.1 \mathrm{~mm}$.

and subdistal inner setae; one outer seta; maxilliped endites separated, narrow, 3.0 L:W, distally with one seta and two slender gustatory cusps. Epignath (Fig. 29J) distally narrowed and pointed.

Cheliped (Fig. 30A,B) sclerite large semitriangular; basis $1.25 \mathrm{~L}: \mathrm{W}$, with one subdistal dorsal seta; merus wedge-shape, with ventral seta; carpus little wider medially, $1.7 \mathrm{~L}: \mathrm{W}$, with two ventral setae, one subdistal and one subproximal dorsal setae; chela slender, 1.2x carpus, $2.25 \mathrm{~L}: \mathrm{W}$; propodus (palm) with one seta near dactylus insertion and five setae on inner side (one long, four short); fixed finger with robust distal spine (unguis), with three inner setae and two ventral setae, cutting margin weakly, irregularly undulate; fixed finger and dactylus unifacial; dactylus 6.5 L:W, almost straight, with two spines on cutting margin and subproximal seta on inner side. 


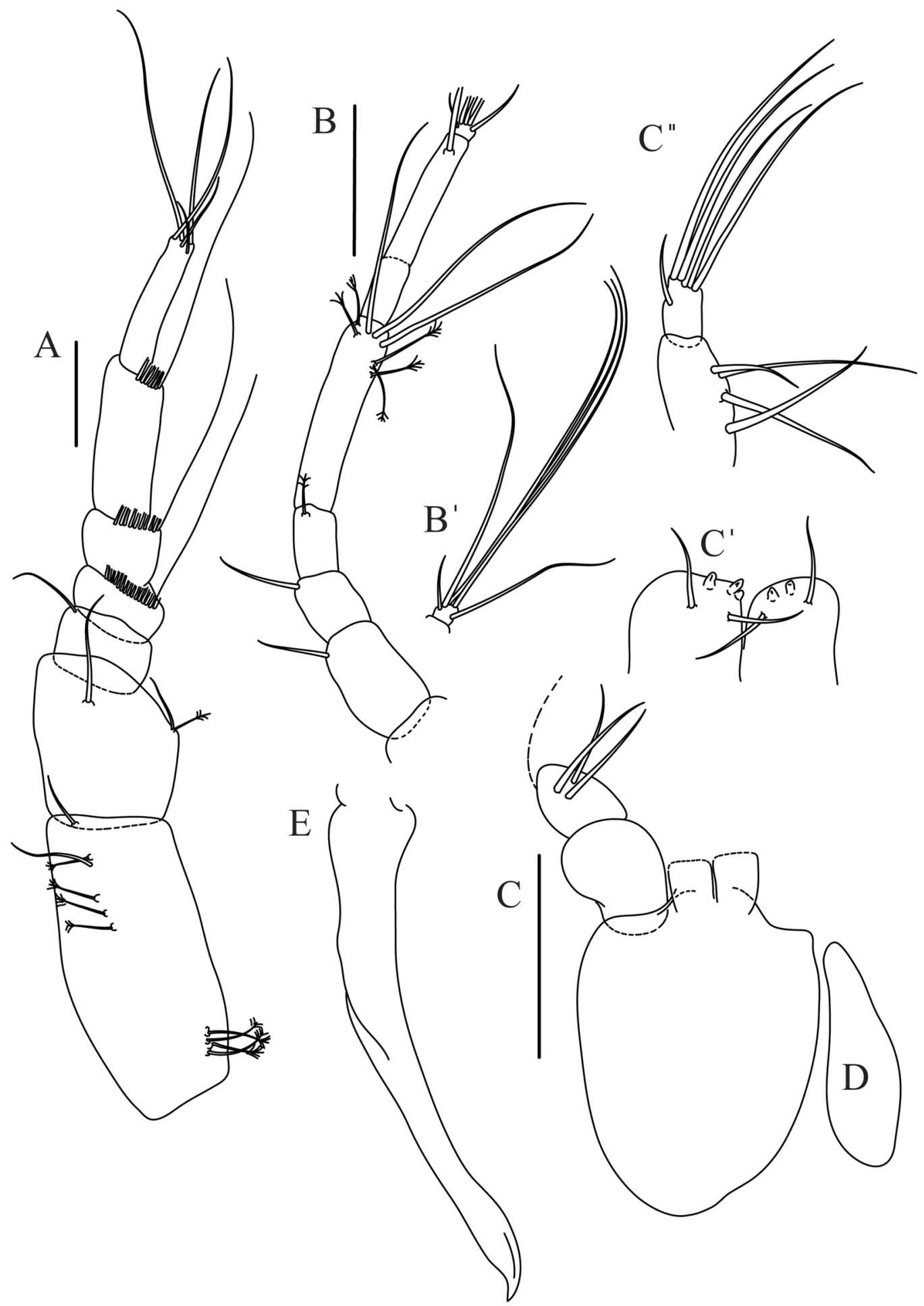

Figure 31. Paranarthrurella samba sp. nov., paratype male (MCZ:IZ:149578) (A) Antennule. (B) Antenna. (C) Maxilliped. (C') Maxilliped, endite distally. (C”) Maxilliped palp distal part. (D) Maxilla. (E) Epignath. Scale $0.1 \mathrm{~mm}$.

Pereopod-1 (Fig. 30C,C') longer than pereopods 2-3; coxa with seta; basis $4.75 \mathrm{~L}: \mathrm{W}$; ischium with seta; merus 3.65 L:W, 0.9x carpus, with ventrodistal fine spine; carpus $4.1 \mathrm{~L}: \mathrm{W}, 0.85 \mathrm{x}$ propodus, with four distal spines (two long fine, one short fine, one robust); propodus 7.0 L:W, 3.5x dactylus, with two distodorsal spines (fine and robust) and one subdistal ventral spine; dactylus $6.4 \mathrm{~L}: \mathrm{W}, 0.5 \mathrm{x}$ unguis; unguis and dactylus about $0.9 \mathrm{x}$ propodus.

Pereopod-2 (Fig. 30D) coxa with seta; basis 5.1 L:W; ischium with ventral seta; merus $3.3 \mathrm{~L}: \mathrm{W}$, 0.8x carpus, with ventrodistal fine spine; carpus $4.1 \mathrm{~L}: \mathrm{W}, 0.95 \mathrm{x}$ propodus with four fine distal spines (three long and one 


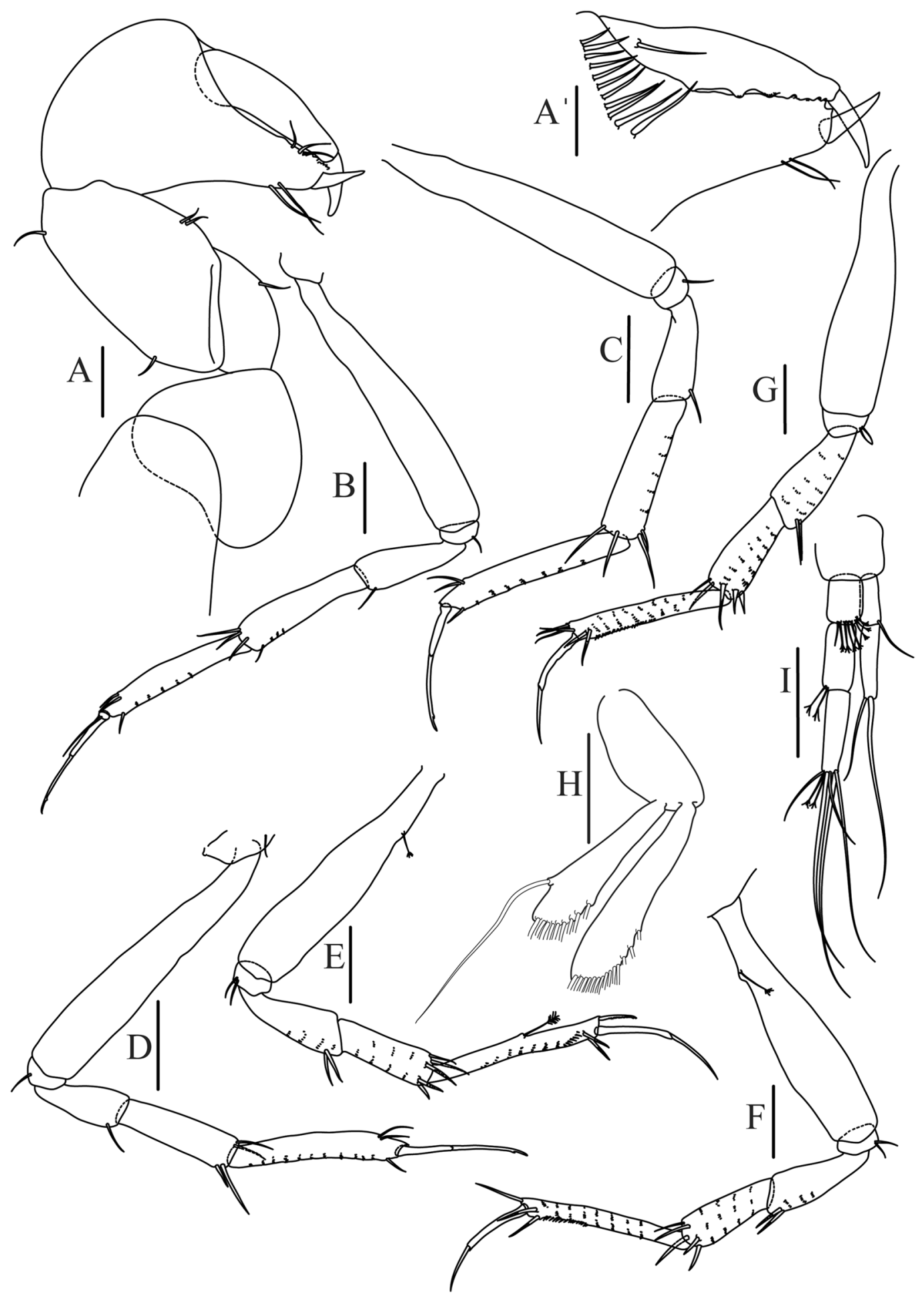

Figure 32. Paranarthrurella samba sp. nov., paratype male (MCZ:IZ:149578) (A) Cheliped. (A’) Chela, inner side. (B-G) Pereopod 1-6, respectively. (H) Pleopod. (I) Uropod. Scale $0.1 \mathrm{~mm}$.

short); propodus 5.6 L:W and 2.7x dactylus, with subdistal ventral spine and two subdistal dorsal spines (robust and fine), ventral margin with microtrichia; dactylus 7.0 L:W, $0.7 x$ unguis; dactylus and unguis 0.9x propodus.

Pereopod-3 (Fig. 30E) similar to pereopod-2, but basis with midventral long penicillate seta.

Pereopod-4 (Fig. 30F) basis 4.3 L:W, naked; ischium with two ventral setae; merus $2.7 \mathrm{~L}: \mathrm{W}$, as long as carpus, with two ventrodistal serrate spines; carpus $2.7 \mathrm{~L}: \mathrm{W}, 0.6 \mathrm{x}$ propodus, with four distal serrate spines and rod-like seta dorsodistally; propodus 7.7 L:W, with penicillate middorsal seta, two ventrodistal serrate spines and one serrate dorsodistal spine; dactylus 8.0 L:W; unguis just shorter than dactylus.

Pereopod-5 (Fig. 30G) similar to pereopod-4, but propodus without dorsodistal penicillate seta. 
Pereopod-6 (Fig. 30H) similar to pereopod-5, but propodus with three dorsodistal spines.

Uropod (Fig. 30I) basal article 1.1 L:W; exopod with two articles, 0.7x endopod, article-1 $2.5 \mathrm{~L}: \mathrm{W}$, with distal seta, article-2 3.7 L:W, with one long and one short distal setae; endopod with two articles, article-1 3.1 L:W, with two penicillate distal setae; article-2 3.5 L:W, with three long one short and two penicillate distal setae.

Description of adult male, length $3.4 \mathrm{~mm}$. Body (Fig. 28C,D) slender, $8.5 \mathrm{~L}: \mathrm{W}$; cephalothorax as long as wide, 2.5x pereonite-1. Pereonites $1-6: 0.5,0.6,0.9,0.8,1.1$ and $0.8 \mathrm{~L}: \mathrm{W}$, respectively; pereonites $1-3$ wider proximally, pereonites 4 and 5 wider medially, pereonite- 6 wider distally. Pleon 0.3 of total body length. All pleonites the same size, 0.4 L:W, with rounded lateral margins, without hyposphaenium. Pleotelson $1.2 \mathrm{x}$ pleonite-5, distal spine $2.0 \mathrm{x}$ pleotelson proximal part.

Antennule (Fig. 31A) article-1 2.1 L:W, 1.75x article-2, with four penicillate and two simple subdistal or distal setae, and four penicillate proximal setae; article-2 1.2 L:W, $2.4 \mathrm{x}$ article-3, with two simple and one penicillate setae subdistally; article-3 0.7 L:W, 1.5x article-4, with distal seta; article-4 0.5 L:W, with numerous aesthetascs arranged in transversal row; article-5 as long as wide, with numerous long aesthetascs arranged in transversal row; article-6 2.7 L:W, with a few aesthetasc distally; article-7 4.6 L:W, with five setae distally.

Antenna (Fig. 31B) 0.6 times length of antennule; article-1 fused with body; article-2 1.7 L:W, 1.8x article-3, with distodorsal seta; article-3 L:W, as long as article-4, with distodorsal seta; article-4 1.6 L:W, 0.3x article-5, with penicillate seta distally; article-5 4.7 L:W, 1.2x article-6, with three simple and five penicillate setae distally; article-6 7.0 L:W, naked with suture at $1 / 3$ of the length and distal seta; article-7 as long as wide, with five long and one short distal setae (Fig. 31B').

Mouthparts. Labrum hood-shape, naked (not illustrated); mandible, maxillule endite, and labium reduced to small plates (not illustrated). Maxilla (Fig. 31D) semiround. Maxilliped (Fig. 31C) basis 1.3 L:W, naked; palp article-1 1.4 L:W, naked; article-2 as long as wide, with three inner setae; article-3 2.0 L:W, with four inner setae (three long, one short); article-4 1.8 L:W, with four distal or subdistal inner setae and one outer seta; maxilliped endites (Fig. 31C') separate, short and narrow, distally with two setae and two slender gustatory cusps. Epignath (Fig. 31E) distally narrowed and pointed.

Cheliped (Fig. 32A,A') sclerite large; basis 1.5 L:W, naked; merus wedge-shape, with ventral seta; carpus little wider medially, 1.7 L:W, with two ventral setae, one subdistal and one subproximal dorsal setae; chela slender, $1.2 \mathrm{x}$ carpus, $1.6 \mathrm{~L}: \mathrm{W}$; propodus (palm) with eleven setae on inner side; fixed finger with irregular inner margin; with three inner setae and two ventral setae; dactylus $4.7 \mathrm{~L}: \mathrm{W}$, almost straight, with at least two calcified spines on inner margin and subproximal seta on inner side.

Pereopod-1 (Fig. 32B) basis 6.8 L:W, naked; ischium with ventral seta; merus 3.0 L:W, 0.75x carpus, with ventrodistal fine spine; carpus 4.4 L:W, 0.9x propodus, with four distal spines; propodus 6.0 L:W, 3.0x dactylus, with two subdistal spines dorsally and one subdistal ventral spine; dactylus $0.8 x$ unguis, with seta reaching end of dactylus; unguis and dactylus about $0.8 x$ propodus.

Pereopods 2 and 3 (Fig. 32C,D) as pereopod-1.

Pereopod-4 (Fig. 32E) basis 5.1 L:W, with dorsoproximal penicillate seta; ischium with two ventral setae; merus 2.5 L:W, as long as carpus, with two ventrodistal spines; carpus 3.1 L:W, 0.6x propodus, with four distal spines and dorsodistal seta; propodus $9.5 \mathrm{~L}: \mathrm{W}$, with penicillate middorsal seta, two ventrodistal serrate spines and one serrate dorsodistal spine; dactylus $10.0 \mathrm{~L}$ : W; unguis $1.1 \mathrm{x}$ dactylus, $0.7 \mathrm{x}$ propodus.

Pereopod-5 (Fig. 32F) similar to pereopod-4, but propodus without dorsodistal penicillate seta.

Pereopod-6 (Fig. 32G) similar to pereopod-4, but basis without penicillate setae; propodus with three dorsodistal spines.

Pleopods (Fig. 32H) basal article 2.1 L:W, exopod 0.9x endopod, 5.5 L:W, with nine distal and ventrodistal and one dorsal long serrate setae; endopod 5.5 L:W, with 14 distal and ventrodistal serrate setae.

Uropod (Fig. 32I) basal article 0.9 L:W; exopod with two articles, 0.6x endopod, article-1 2.6 L:W, with distal seta, article-2 5.0 L:W, with two distal setae; endopod with three articles, article-1 1.5 L:W, with eight penicillate distal setae; article-2 2.1 L:W, with two penicillate distal setae; article-3 4.3 L:W, with five simple and two penicillate distal setae.

Distribution. Paranarthrurella samba sp. nov. is known so far only from the type locality off Brazilian coast, at depth of $3459 \mathrm{~m}$.

Remarks. Paranarthrurella samba is one of five Paranarthrurella species with an elongate body habitus and swollen pleotelson with its apex directed downward. In contrast to P. polonez has smooth lateral margins on the pleonites. The species can be distinguished from P. spinimaxillipeda by the length of pereonite- 1 that is 1.7 times as long as wide (clearly shorter in P. spinimaxillipeda). Finally, the new species is distinguished from $P$. dissimilis by lack of strongly serrate dorsodistal spine in pereopods 4-6 propodus (present in P. dissimilis, see Lang 1972, p. 234).

$P$. samba has clearly less robust appendages (cheliped, pereopods) than $P$. kizomba, and the merus of pereopod-1 is subequal to the carpus (merus shorter than carpus in pereopod-1 of $P$. kizomba). Moreover $P$. samba has slender setae on antenna articles 2-3 (short and robust in P. kizomba) and P. kizomba has a long seta on maxilliped palp article-2, which is not observed in P. samba.

Paranarthrurella spinimaxillipeda (Larsen and Araújo-Silva, 2014)

Cheliasetosatanais spinimaxillipeda: Larsen and Araújo-Silva, 2014: 970-973, Figs 1-4 ${ }^{18}$.

Diagnosis. Body long (>8 L:W). Pereonite-1 0.5 L:W. Pleonites lateral margin smooth (not pointed). Pleonites 2-4 without hyposphaenia. Pleon rounded and swollen, apex small. Cheliped carpus 1.4 L:W. Pereopod-1 merus 


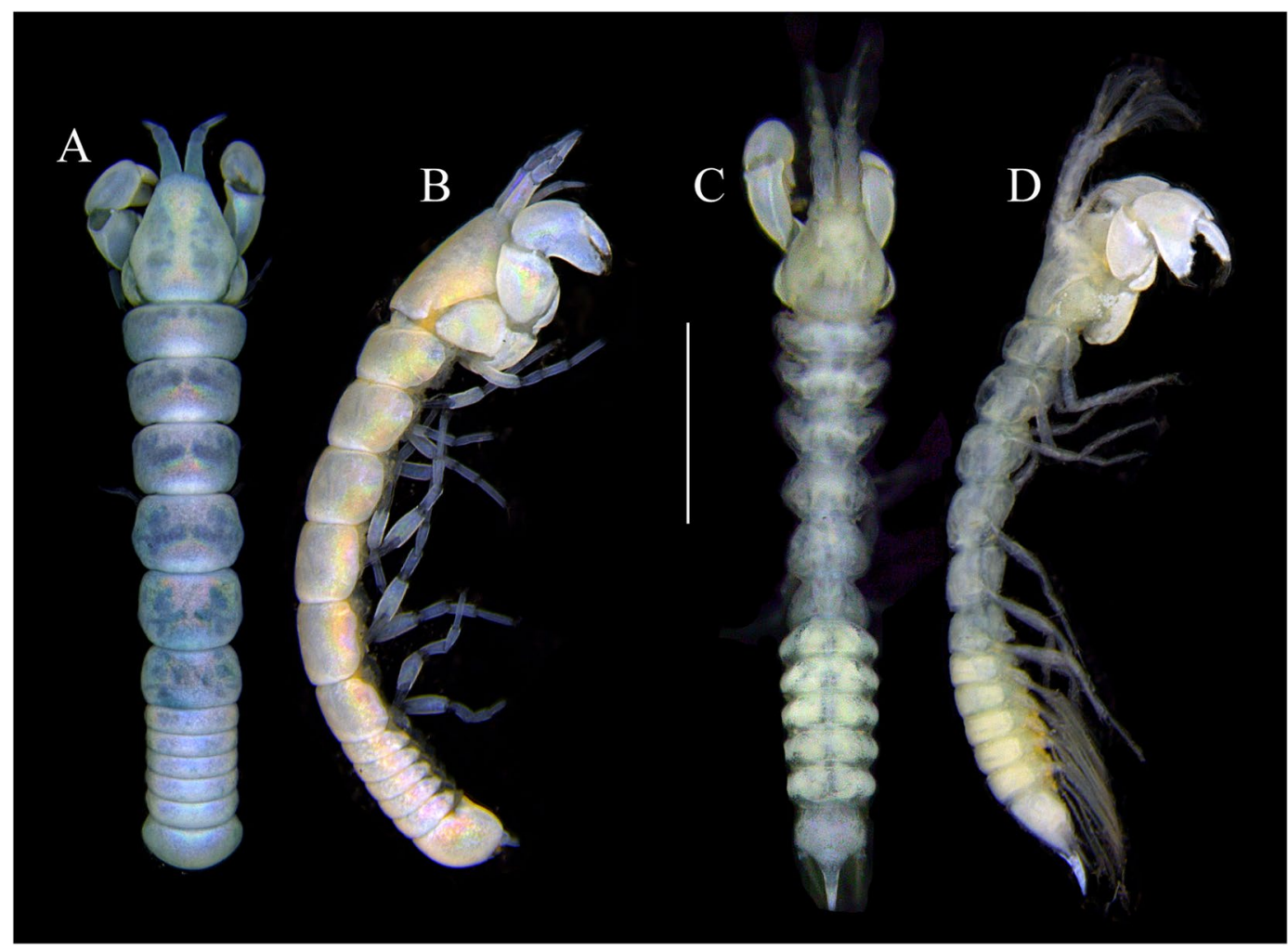

Figure 33. Paranarthrurella tango sp. nov. Holotype, neuter (MCZ:IZ:48363) (A) dorsal and (B) lateral. Paratype male (MCZ:IZ:149570) (C) dorsal and (D) lateral, respectively. Scale $1 \mathrm{~mm}$.

with one spine. Pereopods 4-6 carpus with four spines. Pereopods 4-6 propodus dorsodistal spine finely serrate. Uropod endopod 1.4x exopod.

Remarks. From six species of Panarthrurella which have long body, P. spinimaxillipeda can be distinguished by: rounded pleotelson and small and pointed downward apex (large and pinted backward in P. caudata); smooth lateral margins of pleonites (pointed in $P$. polonez); by presence of weakly serrated spines in propodus of pereopods 4-6 (strongly serrated in $P$. dissimilis) and by short pereonite- 1 that is $0.6 \mathrm{~W} / \mathrm{L}(0.8 \mathrm{~W} / \mathrm{L}$ in $P$. samba) and presence of a long seta on the basis of the maxilliped (no setae in P. samba). For differences between P. spinimaxillipedes and P. kizomba, see remarks above (P. kizomba).

Distribution. The species is known from the Central Pacific, in the Manganese Nodule Province between 4259-4261 m depth.

\section{Paranarthrurella tango Błażewicz and Jóźwiak sp. nov.}

Figures 33-38

Material examined. Holotype, neuter (4.8 mm BL), (MCZ:IZ:48363), RV Atlantis II, Cr. 60, St. 262.

Paratypes: two juvenile males (3.4-3.8 mm BL), (MCZ:IZ:149569); male (2.8 mm BL, partly dissected), (MCZ:IZ:149570); four mancas-2 (1.7-2.3 mm BL), two mancas-3 (1.8-2.1 mm BL), (MCZ:IZ:149571); male (dissected), (MCZ:IZ:149572), two females (dissected), (MCZ:IZ:149548 and MCZ:IZ:149585), the same locality as holotype; two neuters, three mancas-2, one male(?) (MCZ:IZ:48362), RV Atlantis II, Cr. 60, St. 245.

Diagnosis. Female: Body short (<6.5 L:W). Pereonite-1 0.5 L:W. Pleonite 2 and 4 without hyposphaenium; pleonite-3 with small, pointed hyposphaenium. Cheliped carpus 1.2 L:W. Pereopod-1 merus with one fine spine. Pereopods 4-6 carpus with four fine spines. Pereopods 4-6 propodus dorsodistal spine/spines finely serrate. Uropod endopod 1.2x exopod.

Etymology. The species name referring to the Argentinian tango, a social dance originating in the suburbs of Buenos Aires and Montevideo. Noun in apposition.

Description of neuter, length $4.5 \mathrm{~mm}$. Body (Figs 33A,B and 34A,B) short, 5.9 L:W; cephalothorax 1.3 L:W, $2.4 \mathrm{x}$ pereonite- 1 . Pereonites $1-6: 0.5,0.6,0.7,0.6,0.7$ and $0.6 \mathrm{~L}: \mathrm{W}$, respectively; all pereonites wider than long, margins weakly rounded. Pleon 0.25 of total body length. All pleonites the same size, $0.25 \mathrm{~L}$ :W. Pleotelson $2.5 \mathrm{x}$ pleonite-5, rounded, with small and pointed downward apex. 


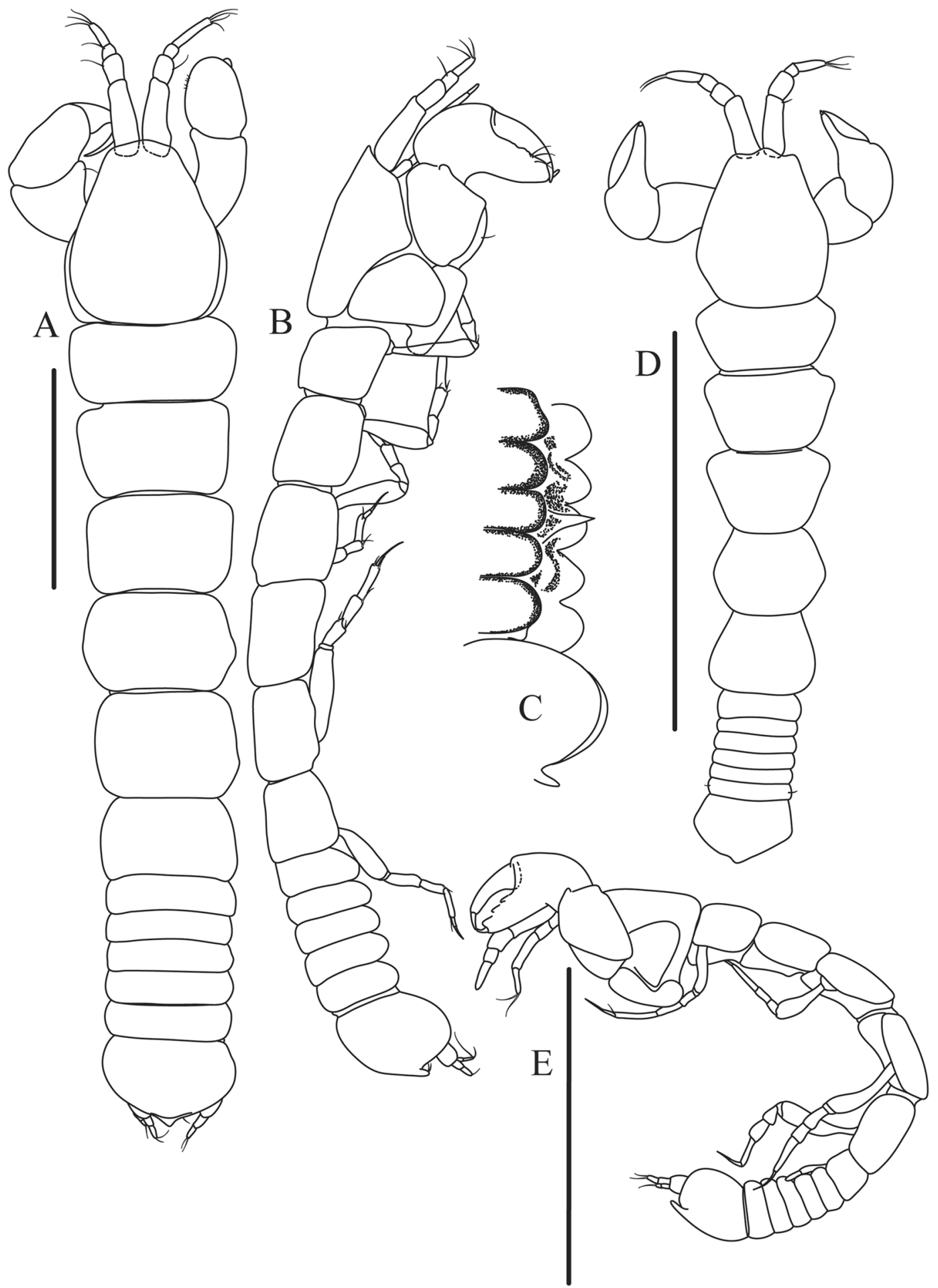

Figure 34. Paranarthrurella tango sp. nov. Holotype neuter (MCZ:IZ:48363). (A) Dorsal and (B) lateral. (C) Pleon, lateral. (D) Manca-2 dorsal (E) manca-3 lateral, respectively (MCZ:IZ:149571). Scale $1 \mathrm{~mm}$.

Antennule (Fig. 35A) article-1 2.1 L:W, 2.5x article-2, with three middle penicillate setae (broken); article-2 1.3 L:W, 2.0x article-3, with two simple and two penicillate distal setae; article-3 $0.9 \mathrm{~L}: \mathrm{W}, 0.4 \mathrm{x}$ article-4, with long and short distal setae; article-4 3.6 L:W, with five long and two short setae, and with aesthetasc, distally.

Antenna (Fig. 35B) 0.85 times length of antennule; article-1 fused with body; article-2 1.7 L:W, 1.8x article-3, with distal seta, situated in right angle to axis of the article; article-3 0.9 L:W, $0.3 x$ article-4, with distal seta, situated in right angle to axis of the article; article-4 $4.75 \mathrm{~L}: \mathrm{W}, 1.6 \mathrm{x}$ article-5, with two simple and one penicillate setae distally; article-5 4.0 L:W, with distal seta; article-6 as long as wide, with four long and one short distal setae. 


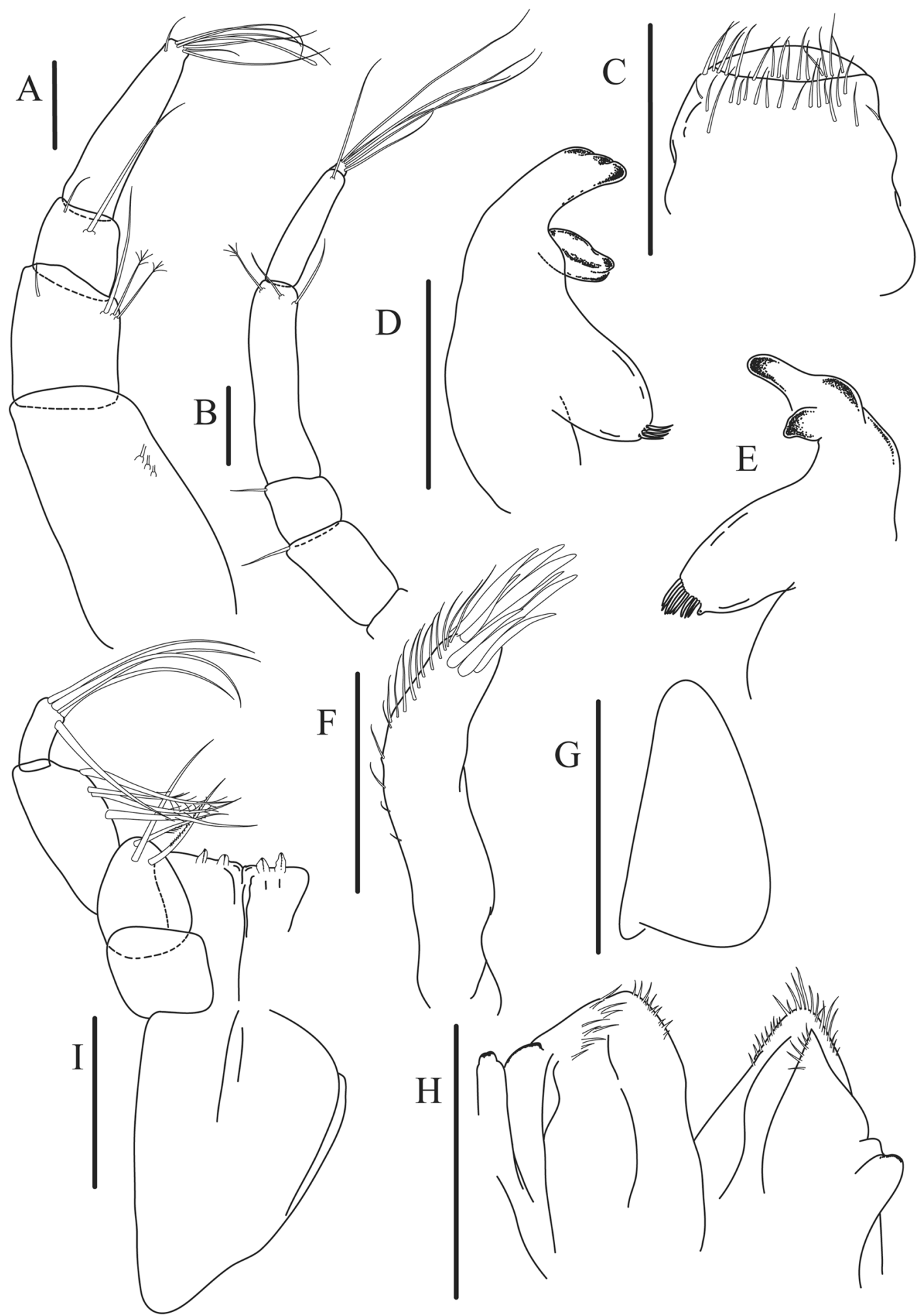

Figure 35. Paranarthrurella tango sp. nov. Paratype, neuter (MCZ:IZ:149548) (A) Antennule. (B) Antenna. (C) Labrum. (D) Mandible, left. (E) Mandible, right. (F) Maxillula. (G) Maxilla. (H) Labium. (I) Maxilliped. Scale $0.1 \mathrm{~mm}$.

Mouthparts. Labrum (Fig. 35C) large elongate; distally obtuse and with sparsely distributed robust setae. Right mandible (Fig. 35E) incisor distally extended, with smooth edge; lacinia mobilis fused with incisor, prominent, pointed, with simple edge; molar lobeform, distally weakly rounded, with eleven weak, finger-shape setae. Left mandible (Fig. 35D) incisor narrow, distally with two perpendicular grooves; lacinia mobilis well developed; molar with four small distal setae. Maxillule endite (Fig. 35F) with nine strong distal spines of various length distally; numerous setae along outer margin; palp not observed. Maxilla (Fig. 35G) semitriangular. Labium (Fig. 35I) with two lobes; inner lobe with spines on distoinner margin and with strong setae distally; outer lobe bilobed, 


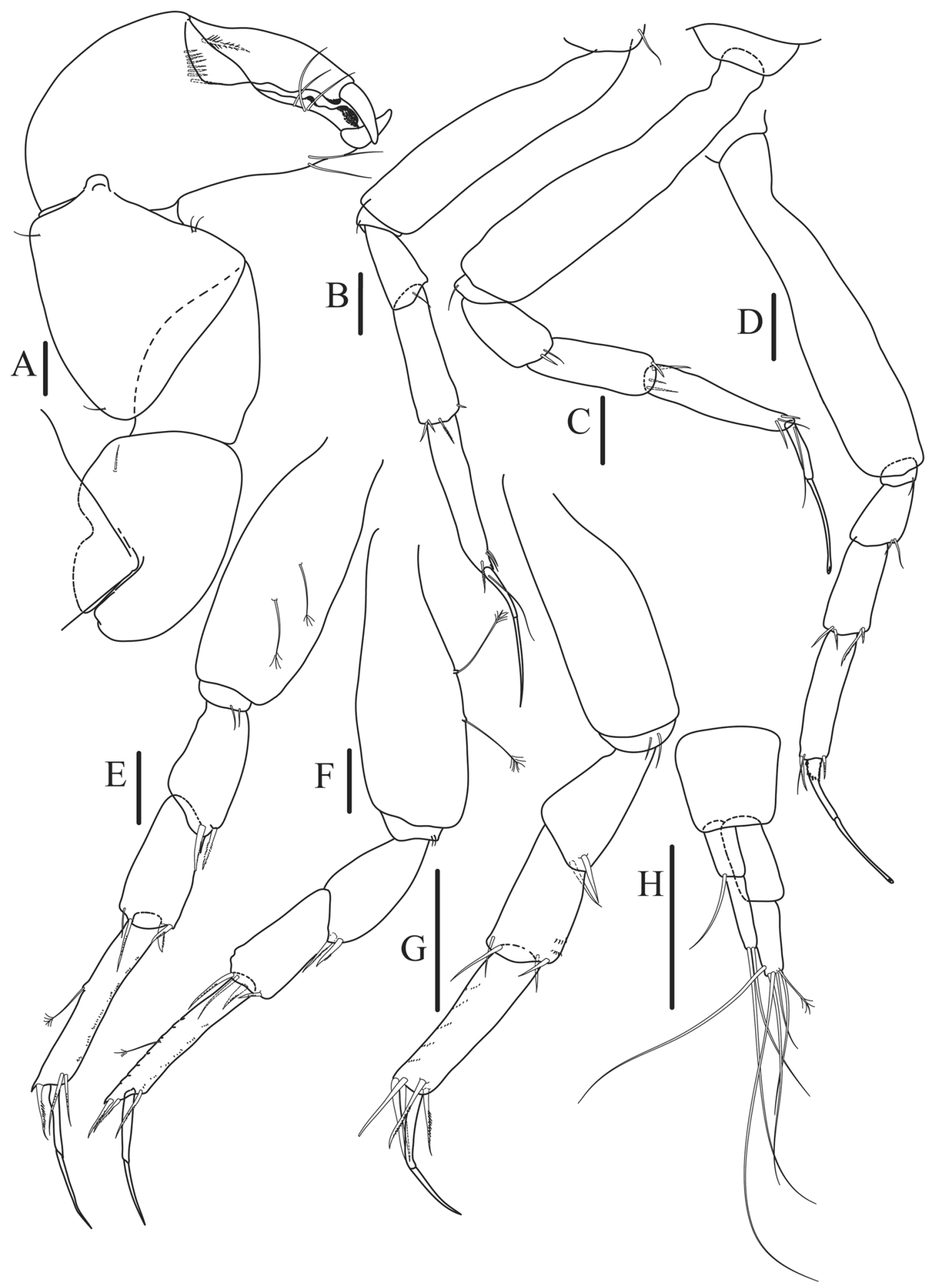

Figure 36. Paranarthrurella tango sp. nov. Paratype, neuter (MCZ:IZ:149548) (A) Cheliped. (B-G) Pereopod $1-6$, respectively. (H) Uropod. Scale $0.1 \mathrm{~mm}$.

smaller than inner lobe. Maxilliped (Fig. 35H) basis 1.6 L:W, naked; palp article-1 1.1 L:W, naked; article-2 1.1 $\mathrm{L}: \mathrm{W}$, with three serrate inner setae; article-3 2.0 L:W, with four inner sparsely serrate setae; article-4 2.3 L:W, with five distal and subdistal inner setae; no outer seta observed; maxilliped endites separate, narrow, 2.25 L:W, distally with two slender gustatory cusps; no distal seta observed. Epignath not seen.

Cheliped (Fig. 36A) sclerite large semitriangular; basis 1.9 L:W, with one subdistal dorsal seta; merus wedge-shape, with ventral seta (broken); carpus 1.2 L:W, with two ventral setae, one subdistal and one subproximal dorsal setae; chela slender, $1.2 \mathrm{x}$ carpus, $1.7 \mathrm{~L}$ :W; propodus (palm) seta near dactylus insertion not seen, eight setae on inner side (one long, seven short); fixed finger with robust distal spine (unguis), with middle (smaller) 


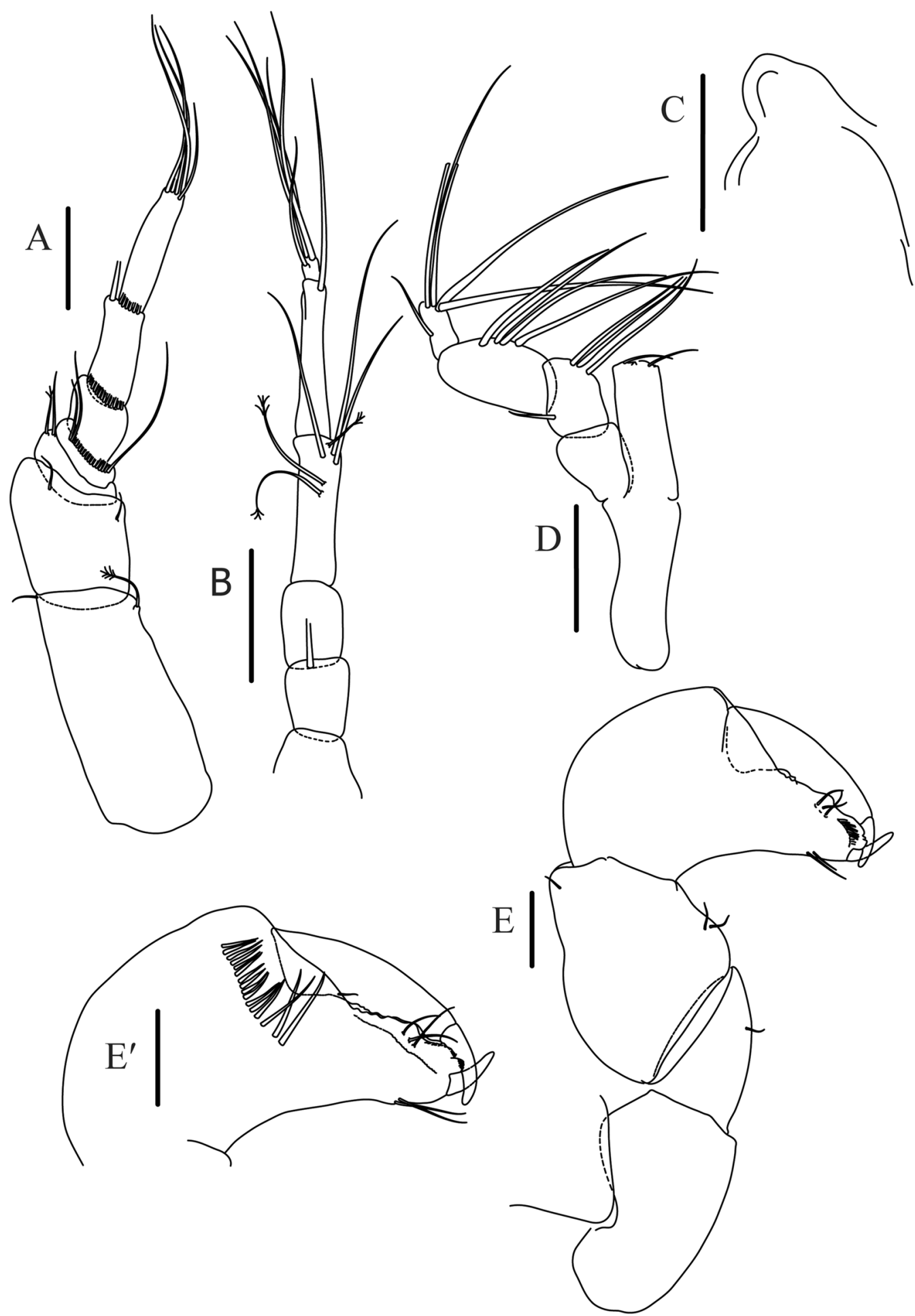

Figure 37. Paranarthrurella tango sp. nov. Paratype, male (MCZ:IZ:149572) (A) Antennule. (B) Antenna. (C) Labrum. (D) Maxilliped. (E) Cheliped. (E') Chela, inner side details. cale $0.1 \mathrm{~mm}$.

and distal (bigger) chitinized teeth on cutting margin and two ventral setae; cutting margin distally well calcified, with three setae; fixed finger and dactylus unifacial; dactylus almost straight, with three spines on cutting margin and subproximal serrate seta on inner side.

Pereopod-1 (Fig. 36B) longer than pereopods 2-3; coxa with seta; basis $4.75 \mathrm{~L}: \mathrm{W}$, naked; ischium with seta; merus 1.7 L:W, $0.7 \mathrm{x}$ carpus with distal fine spine; carpus $2.6 \mathrm{~L}: \mathrm{W}, 0.7 \mathrm{x}$ propodus, with four short distal spines; propodus 4.7 L:W, 2.7x dactylus, with one subdistal ventral serrate spine and two short subdistal dorsal spines (one fine); dactylus $6.4 \mathrm{~L}: \mathrm{W}, 0.6 \mathrm{x}$ unguis, with seta reaching 0.3 of unguis; unguis and dactylus about $0.9 \mathrm{x}$ propodus. 


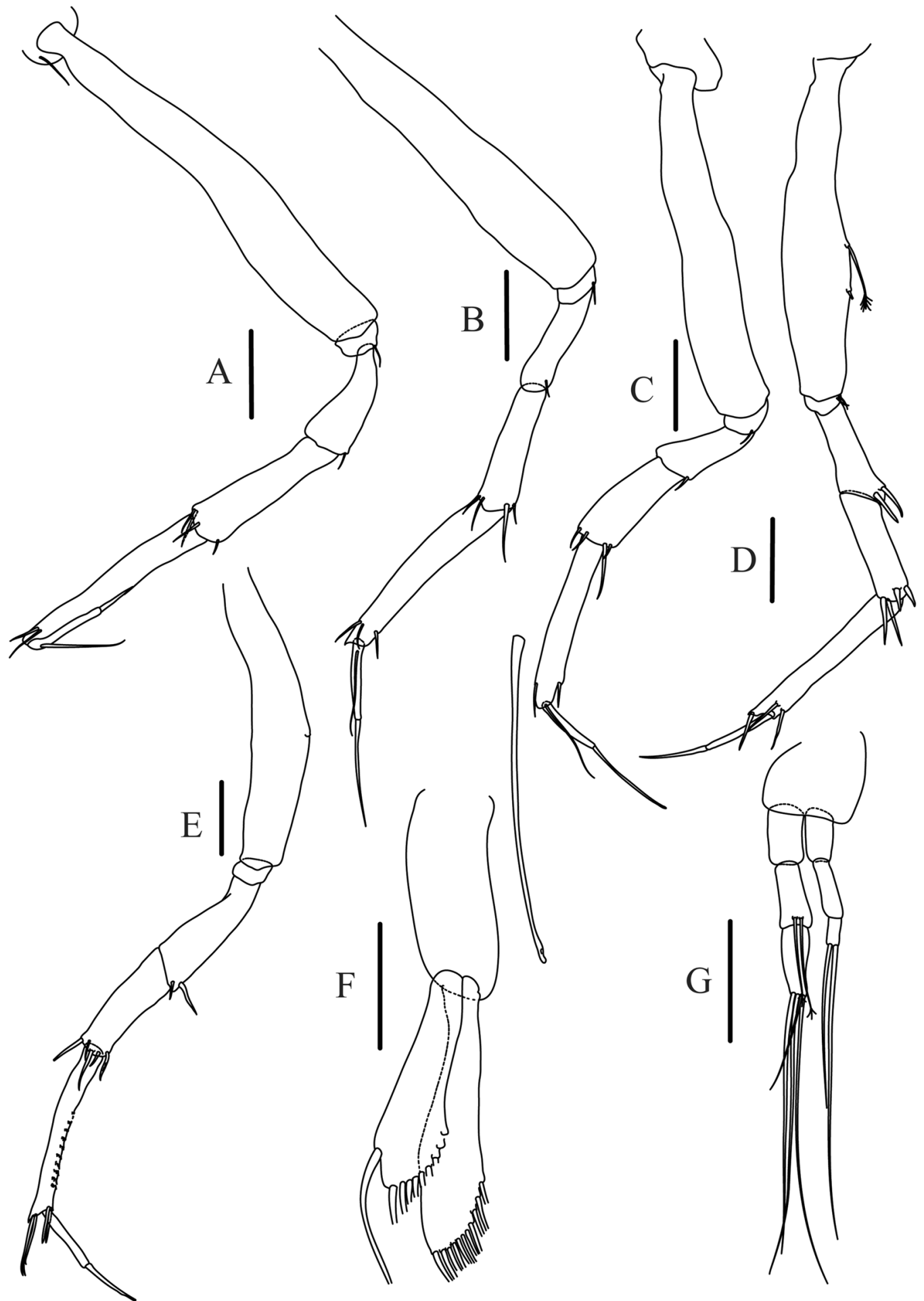

Figure 38. Paranarthrurella tango sp. nov., paratype, male (MCZ:IZ:149572) (A-E) Pereopod 1-4 and 6, respectively. (F) Pleopod. (G) Uropod. Scale $0.1 \mathrm{~mm}$.

Pereopod-2 (Fig. 36C) basis 4.5 L:W, naked; ischium with ventral seta; merus 1.7 L:W, 0.75x carpus, with two spines (one fine) distally; carpus $2.6 \mathrm{~L}: \mathrm{W}, 0.75 \mathrm{x}$ propodus, with four distal spines; propodus $4.7 \mathrm{~L}: \mathrm{W}$ and $2.7 \mathrm{x}$ dactylus, with subdistal ventral spine and two subdistal spines (one fine) dorsally; dactylus 6.4 L:W, 0.6x unguis, with proximal seta.

Pereopod-3 (Fig. 36D) similar to pereopod-2, but dactylus proximal seta not seen.

Pereopod-4 (Fig. 36E) basis $2.5 \mathrm{~L}: \mathrm{W}$, with two penicillate setae on ventral margin; ischium with two ventral setae; merus 1.7 L:W, 0.9x carpus, with two ventrodistal serrate spines; carpus $2.0 \mathrm{~L}: \mathrm{W}, 0.7 \mathrm{x}$ propodus, with three 
serrate spines and fine spine distally; propodus 7.3 L:W, with penicillate middorsal seta, two ventrodistal long serrate spines and one serrate dorsodistal spine; dactylus $8.7 \mathrm{~L}: \mathrm{W}$; unguis $0.8 \mathrm{x}$ dactylus; together $0.8 \mathrm{x}$ propodus.

Pereopod-5 (Fig. 36F) as pereopod-4.

Pereopod-6 (Fig. 36G) similar to pereopod-5, but basis naked; propodus without dorsodistal penicillate seta and with three dorsodistal serrate spines.

Uropod (Fig. $36 \mathrm{H}$ ) basal article 1.1 L:W; exopod with two articles, $0.8 \mathrm{x}$ endopod, article-1 1.8 L:W, with distal seta, article-2 5.0 L:W, with two distal setae; endopod with two articles, article-1 1.9 L:W; article-2 2.8 L:W, with five simple and one penicillate setae distally.

Description of adult male, length $3.4 \mathrm{~mm}$. Body (Fig. 33C,D) slender, $8.5 \mathrm{~L}: \mathrm{W}$; cephalothorax as long as wide, $2.5 x$ pereonite- 1 . Pereonites $1-6: 0.5,0.6,7.9,0.9,1.1$ and $0.8 \mathrm{~L}: \mathrm{W}$, respectively; pereonites $1-3$ wider proximally, pereonites 4 and 5 wider medially, pereonite- 6 wider distally. Pleon 0.15 of total body length. All pleonites the same size, $0.4 \mathrm{~L}: \mathrm{W}$, with rounded lateral margins, without hyposphaenium. Pleotelson $3.2 \mathrm{x}$ pleonite-5, apex $2.0 \mathrm{x}$ pleotelson proximal part.

Antennule (Fig. 37A) article-1 2.3 L:W, 2.1x article-2, with one penicillate and one simple distal setae; article-2 1.2 L:W, 3.9x article-3, with two short distal setae; article-3 0.4 L:W, 1.8x article-4, with two setae distally; article-4 $0.2 \mathrm{~L}: \mathrm{W}, 0.3 \mathrm{x}$ article-5, with numerous long aesthetascs arranged in transversal row; article-5 $0.8 \mathrm{~L}: \mathrm{W}, 0.5 \mathrm{x}$ article-6, with numerous long aesthetascs arranged in transversal row; article-6 2.4 L:W, 0.8x article-7, with few aesthetascs distally, article $74.0 \mathrm{~L}: \mathrm{W}$, with five setae distally.

Antenna (Fig. 37B) 0.6 times of antennule length; article-1 fused with body; article-2 1.4 L:W, 0.9x article-3, with distal seta (broken); article-3 1.4 L:W, 0.6x article-4, no seta observed; article-4 3.6 L:W, 0.9x article-5, with three simple and three penicillate distal and subdistal setae; article-5 7.0 L:W, with simple distal seta; article-6 as long as wide, with five distal setae.

Mouthparts. Labrum (Fig. 37C) hood-shape, naked; mandible, maxillule endite, maxilla and labium reduced to small plates (not illustrated). Maxilliped (Fig. 37D); palp article-1 1.2 L:W, naked; article-2 1.3 L:W, with three inner and one outer setae; article-3 1.7 L:W, with four long inner setae; article-4 2.9 L:W, with five distal and subdistal inner setae and outer seta; maxilliped endites separated, narrow, distally with two setae and at least one gustatory cusp. Epignath not seen.

Cheliped (Fig. 37E) sclerite semitriangular; basis $2.1 \mathrm{~L}: \mathrm{W}$; merus wedge-shape, with small ventral seta; carpus little wider medially, 1.5 L:W, with two ventral setae, one dorsodistal seta, dorsoproximal seta not seen; chela slender, $0.7 \mathrm{x}$ carpus, $1.6 \mathrm{~L}$ :W; propodus (palm) with 16 setae on inner side (Fig. 37E'); fixed finger with calcified inner margin distally, divided by transversal grooves, with three setae on cutting edge and two ventral setae; dactylus 5.3 L:W, unguis bent downward.

Pereopod-1 (Fig. 38A) coxa with seta; basis 7.6 L:W, naked; ischium with seta; merus $2.6 \mathrm{~L}: \mathrm{W}, 0.7 \mathrm{x}$ carpus, with ventrodistal small spine; carpus $4.2 \mathrm{~L}: \mathrm{W}, 0.8 \mathrm{x}$ propodus, with four fine distal spines (one small); propodus 7.9 L:W, 2.5x dactylus, with two unequal, fine dorsodistal spines (ventral spine not observed); dactylus 9.0 L:W, with proximal seta; unguis about half as long as dactylus.

Pereopod-2 (Fig. 38B) similar to pereopod-1, but propodus 5.9 L:W, with subdistal ventral spine distally; dactylus 7.8 L:W, 0.6x unguis; dactylus and unguis subequal propodus.

Pereopod-3 (Fig. 38C) similar to pereopod-2, but propodus with one subdistal spine dorsally.

Pereopod-4 (Fig. 38D) basis 5.6 L:W, with two dorsoproximal penicillate seta; ischium with two ventral setae; merus 3.1 L:W, as long as carpus, with two ventrodistal spines; carpus $3.7 \mathrm{~L}: \mathrm{W}, 0.7 \mathrm{x}$ propodus, with four distal spines; propodus 8.3 L:W, with two ventrodistal spines and one dorsodistal spine; dactylus $10.6 \mathrm{~L}: \mathrm{W}$; unguis $1.1 \mathrm{x}$ dactylus, combined $0.8 \mathrm{x}$ propodus.

Pereopod-5 (not illustrated) as pereopod-4.

Pereopod-6 (Fig. 38E) similar to pereopod-4, but propodus with three dorsodistal spines.

Pleopods (Fig. 38F) basal article 2.5 L:W, exopod 0.8x endopod, 5.2 L:W, with nine distal and ventrodistal plumose setae and dorsal long plumose seta; endopod 5.5 L:W, with eleven distal and ventrodistal plumose setae.

Uropod (Fig. 38G) basal article 0.9 L:W; exopod with three articles, 0.8x endopod, article-1 2.1 L:W, naked, article-2 3.5 L:W, naked; article-3 2.4 L:W, with two distal setae; endopod with three articles, article-1 1.8 L:W, naked; article-2 2.5 L:W, with two penicillate distal setae; article-3 $2.9 \mathrm{~L}: \mathrm{W}$, with three long and one short distal setae.

Distribution. The species is known only from the type locality located off the Argentinian coast at the depth 2440-2707 m.

Remarks. Paranarthrurella tango sp. nov. is the third species with short body and hyposphaenium only on pleonite-3; this hyposphaenium is small, distinguishing it from $P$. arctophylax (see remarks page 15). Another species with a small hyposphaenium on pleonite-3 is $P$. rocknroll. Those two species can be distinguished by character of the distal seta on the propodus of pereopods $4-6$ that is strongly serrate in P. rocknroll and serrated in P. tango.

Paranarthrurella voeringi (G.O. Sars, 1877)

Tanais voringi: G.O. Sars, $1877: 2,347-370^{6}$

Cryptocope voringii: G.O. Sars, 1882: 7, 50-51 ${ }^{7}$; G.O. Sars, 1885: 6, 74-78, pl.VII' ${ }^{61}$; Hansen, 1913: 3, 109-110, pl. X ${ }^{8}$.

Tanais voeringi: Sieg, 1980: 537, 11-12 $2^{82}$.

Leptognathia voeringi: Sieg, 1983: $356^{72}$; Sieg 1986: $170^{73}$

Biarticulata voeringi: Larsen and Shimomura, 2007: $19^{13}$

Paranarthrurella voeringi: Jóźwiak et al., 2009: 59 [partially] ${ }^{16}$.

Paranarthrurella voeringi: Błażewicz-Paszkowycz and Bamber, 2011: $31^{83}$ 


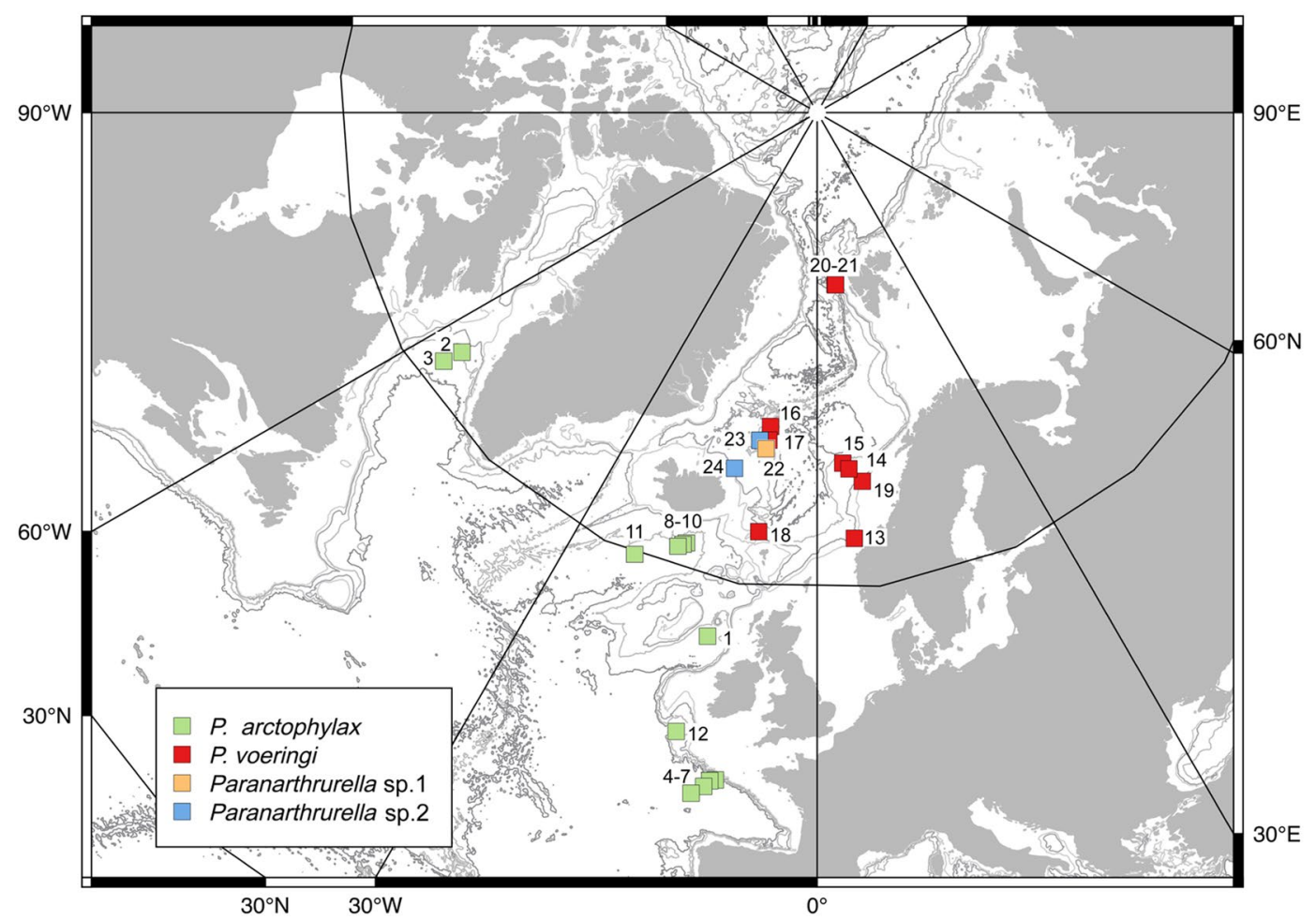

Figure 39. Distribution of the septentrional Paranarthrurella species (P. arctophylax, P. voeringi, Paranarthrurella sp.1 and Paranarthrurella sp.2) in the North Atlantic, based on the literature data (see Table 5) and current study.

Diagnosis. Body short (<6.5 L:W). Pereonite-1 0.4 L:W. Pleonite 2-4 with distinct, directed backward hyposphaenium (hypospahaenium on pleonite- 4 smaller than on preonites 2-3). Cheliped carpus 1.2 L:W. Pereopod-1 merus with two spines. Pereopods 4-6 carpus with four spines. Pereopods 4-6 propodus dorsodistal spine finely serrate. Uropod endopod 1.2x exopod.

Distribution. The species was primarily described by G.O. Sars in 1877 from off Storeggen Bank at $763 \mathrm{~m}$ depth the 29th June 1876 (St 31$)^{6}$. On a second cruise carried out in 1877, a few specimens were obtained at 2 other localities (St 124, 248), off coast of Helgeland from 640 and $1423 \mathrm{~m}$ depth, respectively. Latter the species was recorded by Hansen ${ }^{8}$ in the North Atlantic during the Ingolf expedition, northwestern Faeroes (St 138) and southern Jan Mayen (St 116, 117), in the depth range from 678.5 to $1835 \mathrm{~m}$. Recently, the species was rediscovered in Arctic waters at the observatory HAUSGARTEN, in the eastern Fram Strait at two stations at the depth $1273-1300 \mathrm{~m}$, and in the neighbourhood of the type locality at $742 \mathrm{~m} \mathrm{depth}{ }^{16}$. Its distribution depth ranges between 640-1835 m (Table 5, Fig. 39).

Remarks. $\quad P$ voeringi is the only species that has hyposphaenia on pleonites 2 to 4 .

Paranarthrurella sp.1

Material examined. Three individuals: ind. ITan159 (ZMH K-55996), ind. ITan163 (ZMH K-55997); ind ITan164 (ZMH K-55998), RV Meteor, IceAGE1, St. 1155.

Remarks. See remarks under Paranarthrurella sp.2 (below).

\section{Paranarthrurella sp.2}

Material examined. Three individuals: ind. ITan 158 (ZMH K-55999), ind. ITan160 (ZMH K-56000), ind. ITan161 (ZMH K-56001) RV Meteor, IceAGE1, St. 1155; two individuals: ITan170 (ZMH K-56002), ind ITan162 (ZMH K-56003), RV Meteor, IceAGE1, St. 1191.

Remarks. Paranarthrurella sp.1 and Paranarthrurella sp.2 are genetically discriminated species, but both are morphologically identical with $P$. voeringi. The latter species was considered cold-water taxon ${ }^{8}$ recorded in relatively shallower waters $(<2000 \mathrm{~m})$ than the congener $-P$. arctophylax, which although known from the depth ( $>2000 \mathrm{~m}$ ), was considered a "warm" water species (Table 5, Fig. 39). In the material studied by us, all of the individuals had distinctive hyposphaenia on pereonites from $2-4$, thus morphologically are similar to $P$. voeringi 
and both occur at the depths typical for $P$. voeringi (St 1155 and 1191, depth 1577-1578 and 2177-2174 m, respectively; Table 5). Generally, we might assume that one of our two genetically distinguished species is $P$. voeringi. However, the decision which of them would truly represent the latter requires further molecular investigations which will include individuals of $P$. voeringi from a type locality.

\section{Identification key to females of Paranarthrurella species}

(modified after Jóźwiak et al..$^{16}$; distribution data according to current study and: Sars G.O. ${ }^{6,61}$; Norman and Stebbing ${ }^{12}$; Hansen ${ }^{8}$; Kudinova-Pasternak ${ }^{2}$; Lang ${ }^{9}$; Holdich and Bird, $1985^{81}$; Jóźwiak et al. ${ }^{5}$; Błażewicz-Paszkowycz and Bamber ${ }^{83}$; Larsen and Araújo-Silva ${ }^{18}$ ).

1 Pleotelson rectangular, apex large directed backward. Pereopods 4-6 carpus with three spines

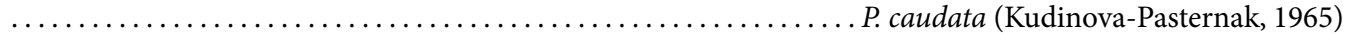

Bougainville Trench; 7947-8006 m

- Pleotelson round, apex small pointed downward. Pereopods $4-6$ carpus with four spines ............2

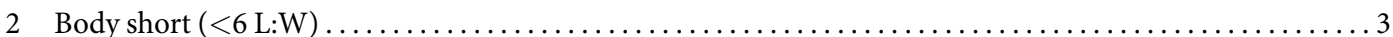

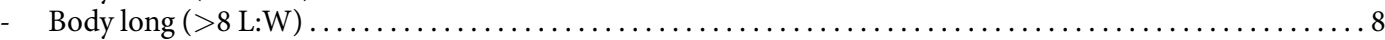

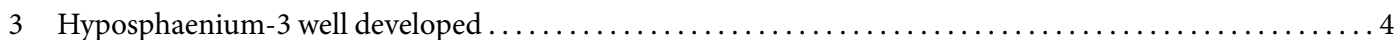

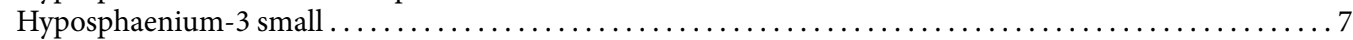

4 Hyposphaenium-4 present. P. voeringi (G.O. Sars, 1877 )

Hyposphaenium-4 absent NE Atlantic (Norwegian Sea) and Arctic; 640-1835 m

5 Hyposphaenium-2 small. Hyposphaenium-2 absent ............. N Atlantic (David Strait, Iceland and Rockall basins, Bay of Biscay); 1970-4720 m

6 Cheliped carpus slender (1.4 L:W) P. corroboree sp. nov. Cheliped carpus robust (1.1 L:W) SE Australia (Bass Strait); 1450-1975 m P. moonwalk sp. nov. NW Atlantic (Gay Head-Bermuda transect); $2178 \mathrm{~m}$

7 Pereopods $4-6$ propodus distodorsal spine strongly serrate ................... rocknroll sp. nov. NW Atlantic (Gay Head-Bermuda transect) 2440-2707 m Pereopods 4-6 propodus distodorsal spine finely serrate . . P. tango sp. nov. SW Atlantic (Argentine Basin); 2440-2707 m

8 Pleonites lateral margin pointed... NE Pacific (Clarion Clipperton Zone); $4365-4823$ m

Pleonites lateral margin smooth

9 Pereopods 4-6 with distodorsal spine strongly serrate P. dissimilis (Lang, 1972) Pereopods 4-6 with distodorsal spine weakly serrate . NW Atlantic (Sargasso Sea); $6000 \mathrm{~m}$

10 Pereonite 1 long (almost as long as wide). Pereonites 1-3 merus with robust and fine spines Pereonite 1 short (clearly shorter than wide). Pereonites $1-3$ merus with fine spines only ..P. spinimaxillipeda (Larsen and Araújo-Silva, 2014) NE Pacific (Clarion Clipperton Zone); 4259-4261 m

11 Pereopods 1-3 merus with robust spines, maxilliped palp article-3 with simple long seta $\ldots \ldots \ldots \ldots \ldots$.

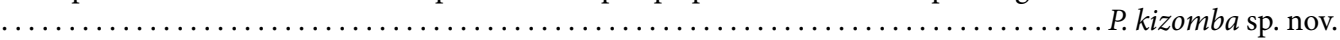
N Atlantic (Vema Fracture Zone); 5127-5137 m Pereopods 1-3 merus fine spine, maxilliped palp article-3 with short setae only. SW Atlantic (N Brazilian Basin); $3459 \mathrm{~m}$

Genus Armatognathia Kudinova-Pasternak, 1987.

Armatognathia Kudinova-Pasternak 1987: 28, 30-31, 36 ${ }^{17}$; Gutu and Sieg 1999: 384 $4^{84}$; Larsen and Wilson, 2002: 217, 218, Table $1^{15}$; Larsen 2005: 242 ${ }^{85}$; Bird and Larsen 2009: Table ${ }^{48}$; Jóźwiak, Stępień and Błażewicz-Paszkowycz 2009: 56, 58 ${ }^{16}$; Larsen, Gutu and Sieg 2015: $304^{77}$. Armathognathia [sic] Larsen and Wilson, 2002: Table $1^{15}$.

Arthrura Kudinova-Pasternak 1973, in part: $162-164^{86}$; Sieg 1986: $168^{73}$; Bird and Holdich 1989: $138^{19}$; Jóźwiak and Błażewicz-Paszkowycz 2011: $47^{87}$.

Type species: Armatognathia birsteini Kudinova-Pasternak, 1987 


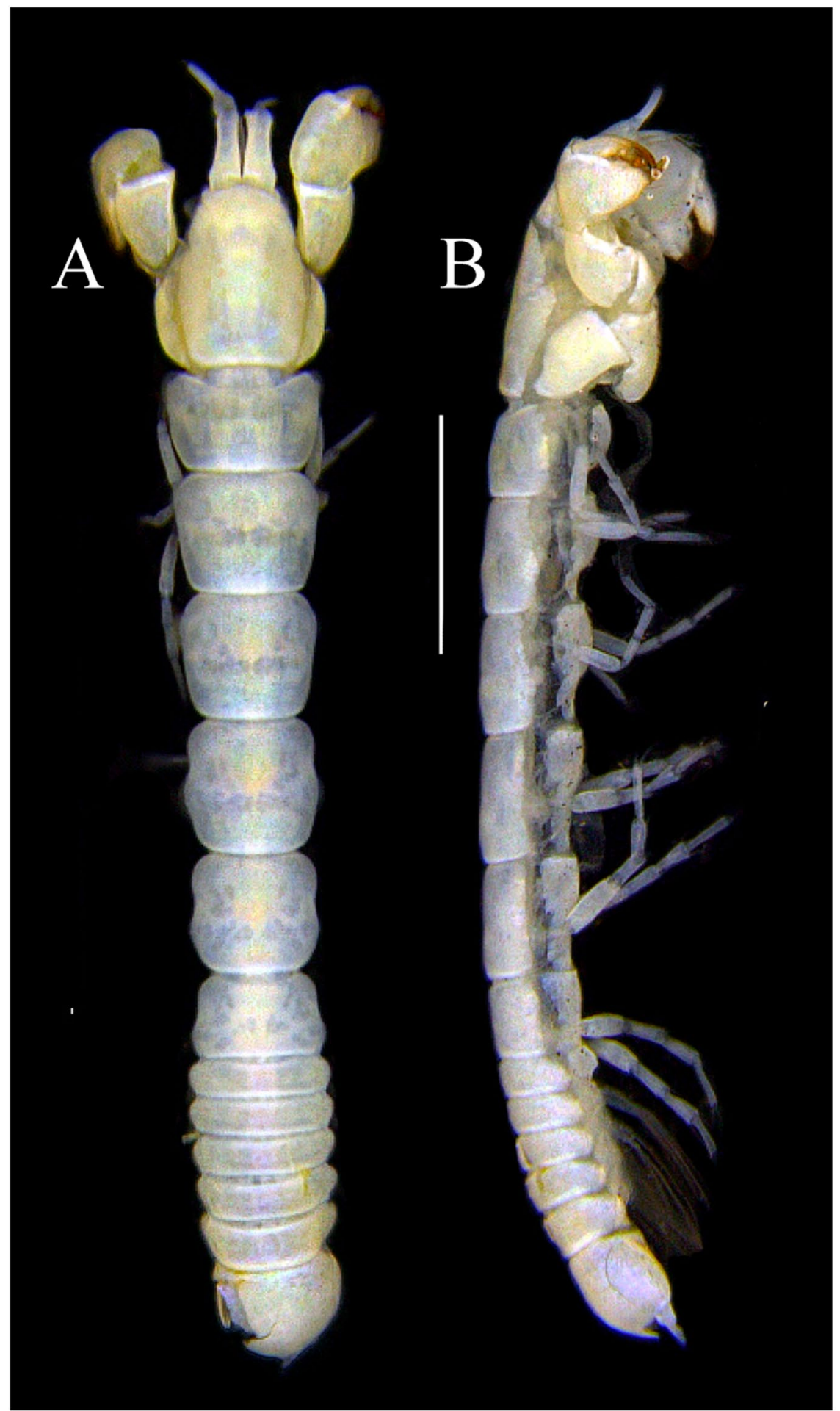

Figure 40. Armatognathia milonga sp. nov., holotype, ovigerous female (ZMH K-56004) (A,B) dorsal and lateral view, respectively. Scale $1 \mathrm{~mm}$.

Species included: Armatognathia birsteini Kudinova-Pasternak, 1987; A. milonga sp. nov.; A. shiinoi (Kudinova-Pasternak, 1973); A. swing sp. nov.

Diagnosis. Female. Body elongate (8-10 L:W). Antenna article-2 with dorsodistal spine. Molar with spines. Maxilliped endites with round gustatory cusps. Cheliped basis posterior part long (dorsal concave in midlength). Cheliped carpus short (1.0-1.1 L:W). Chela robust (usually $<1.3 \mathrm{~L}: \mathrm{W})$. Pleopods present. Uropod endopod article-1 longer than article-2. 


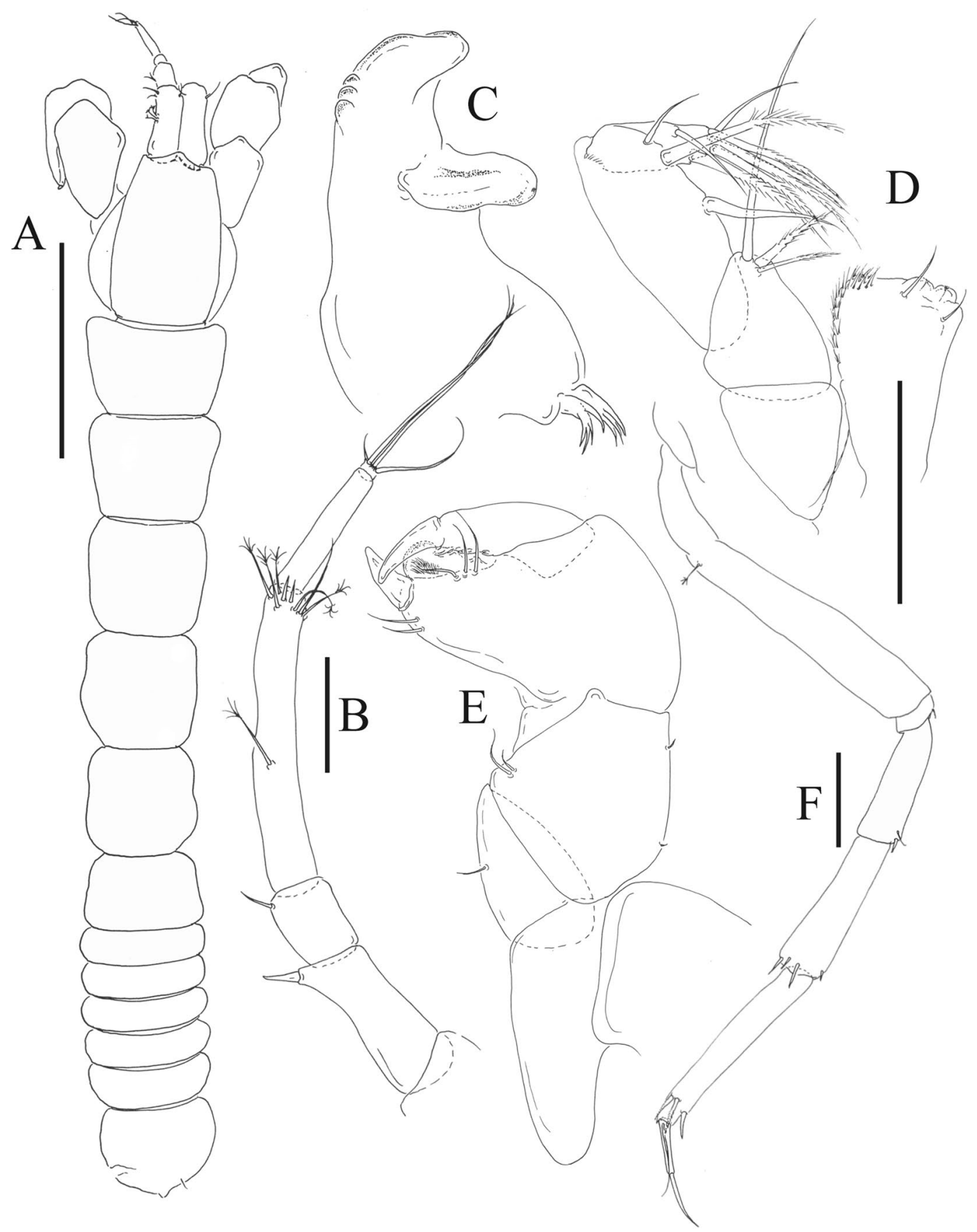

Figure 41. Armatognathia milonga sp. nov., holotype (ZMH K-56004) (A) Female, dorsal view. (B) Antenna. (C) Mandible left. (D) Maxilliped. (E) Cheliped. (F) Pereopod-1. Scale $0.1 \mathrm{~mm}$.

\section{Armatognathia birsteini Kudinova-Pasternak, 1987}

Diagnosis. Carapace long, 2.0 L:W. Pereonite-1 0.7 L:W, pereonites 2-5 longer than wide. Antenna article-4 $2.4 \mathrm{x}$ article-5. Mandible molar with one strong and two weak setae. Pereopod-1 merus with one spine, carpus with short spines only. Pereopod-6 carpus with four spines.

Remarks. From all Armatognathia species A. birsteini has the most elongate carapace that is $2.0 \mathrm{~L}: \mathrm{W}$. Also it is distinguished from $A$ shiinoi by absence of a long spine on the pereopod-1 carpus present in $A$. shiinoi $i^{17}$.

Distribution. The species is known from the type locality in the Madagascar Basin of the Indian Ocean from 3923 to $4365 \mathrm{~m}$ depth. 
Armatognathia milonga Błażewicz and Jóźwiak sp. nov.

Figures 40 and 41

Material examined. Holotype, ovigerous female (4.6 mm BL), (ZMH K-56004), RV Meteor, DIVA3, St. 533.

Diagnosis. Female. Carapace long, 1.7 L:W. Pereonite-1 0.7 L:W, pereonites 2-5 subsquare; pereonites 1-3 weakly wider proximally; pereonites 3-5 lateral almost parallel. Antenna article-4 2.1x article-5. Mandible molar with two serrate spines. Pereopod-1 merus with small spine and seta. Pereopods 4-6 carpus with four spines.

Etymology. The name is after milonga, the music and dance originated in Argentina. Noun in apposition.

Description of neuter, length $3.6 \mathrm{~mm}$. Body (Fig. 41A) slender 9.1 L:W; cephalothorax 1.7 L:W, 2.0x pereonite-1. Pereonites $1-6: 0.7,0.9,1.0,1.0,1.0$ and $0.7 \mathrm{~L}: \mathrm{W}$, respectively. Pleon 0.25 of total body length. All pleonites the same size, $0.3 \mathrm{~L}$ :W. Pleotelson $2.5 \mathrm{x}$ pleonite-5. Pleotelson rounded, apex small, directed downward.

Antenna (Fig. 41B) article-1 fused with body; article-2 3.0 L:W, 1.7x article-3, with distal spine; article-3 1.4 $\mathrm{L}: \mathrm{W}, 0.25 \mathrm{x}$ article-4, with distal seta; article-4 6.9 L:W, 2.0x article-5, with three short, one long simple, five penicillate setae distally and penicillate midlength seta; article-5 4.0 L:W, naked; article-6 as long as wide, with three long and two short distal setae.

Mouthparts. Left mandible (Fig. 41C) incisor distally blunt, margin weakly crenulate; lacinia mobilis large, with simple edge; molar distally rounded, with two distally multifurcate spines. Maxilliped (Fig. 41D) basis not observed; palp article-1 0.9 L:W, naked; article-2 1.1 L:W, with three serrate inner setae (one very long); article-3 1.9 L:W, with three inner setae (fourth seta not seen); article-4 2.5 L:W, with five distal and subdistal inner, sparsely serrate setae and outer seta; maxilliped endites separate, $2.2 \mathrm{~L}: \mathrm{W}$, distally with two round gustatory cusps and two distal setae.

Cheliped (Fig. 41E) sclerite large semitriangular; basis $2.8 \mathrm{~L}: \mathrm{W}$, subdistal dorsal seta not seen; merus wedge-shape, with ventral seta; carpus 1.2 L:W, with two ventral setae, one subproximal and one subdistal setae dorsally; chela robust $1.3 \mathrm{x}$ carpus, $1.5 \mathrm{~L}$ :W; propodus (palm) seta near dactylus insertion not seen; fixed finger with robust distal spine, with three setae on cutting margin and two ventral setae; cutting margin robust and well calcified; fixed finger and dactylus unifacial; dactylus with spines on cutting margin, subproximal seta on inner side not seen, robust unguis bent downward.

Pereopod-1 (Fig. 41F) basis 7.8 L:W, with subproximal penicillate seta on dorsal margin; ischium with seta; merus 3.2 L:W, 0.9x carpus, with small spine and seta; carpus $3.9 \mathrm{~L}: \mathrm{W}, 0.8 \mathrm{x}$ propodus, with four small distal spines; propodus 7.0 L:W, 2.8x dactylus, with one ventrodistal and two dorsodistal serrate spines; dactylus 9.0 $\mathrm{L}: \mathrm{W}, 1.1 \mathrm{x}$ unguis, proximal seta reaching 0.3 unguis length; unguis and dactylus about $0.6 \mathrm{x}$ propodus.

Distribution. The species is known only from the type locality in the Argentine Basin at 4601-4607 $\mathrm{m}$ depth.

Remarks. Armatognathia milonga sp. nov. can be distinguished from all congeners by the presence of a small spine and seta on pereopod-1 merus, where all other species have one (often robust) spine only.

Armatognathia shiinoi (Kudinova-Pasternak, 1973)

Arthrura shiinoi: Kudinova-Pasternak, 1973: 162-164, Fig. $13^{86}$.

Diagnosis. Carapace long, 1.5 L:W. Pereonite-1 0.8 L:W, pereonites 2-5 subrectangular, pereonites 1-3 weakly wider proximally; pereonites $4-5$ wider in midlength. Antenna article-4 $3.5 \mathrm{x}$ article-5. Mandible molar with four spines. Pereopod-1 merus with robust spine, carpus with long distodorsal spine. Pereopods $4-6$ carpus with four spines.

Remarks. Presence of a long distodorsal spine on the pereopod-1 carpus is a unique character that distinguishes Armatognathia shiinoi from all other member of the genus.

Distribution. The species is known only from the Gulf of Alaska at 3450-3460 m depth.

Armatognathia swing Błażewicz and Jóźwiak sp. nov.

Figures 42-48

Material examined. Holotype, neuter (4.0 mm BL), (MCZ:IZ:48509) Gay Head-Bermuda transect, RV Atlantis II, Cr. 24, St. 122.

Paratypes. male (4.0 mm BL) (MCZ:IZ:149573); four neuters (3.5-3.63 mm BL), two mancas-2 (2.3-3.5 mm BL), (MCZ:IZ:149574) (Fig. 42C); female (dissected), (MCZ:IZ:149575), male (dissected), (MCZ:IZ:149583), the same locality as holotype; manca-3 (2.8 mm BL) (MCZ:IZ:48515), RV Chain, Cr. 58, St. 100; manca-3 (3.0 mm BL), (MCZ:IZ:48541), RV Atlantis II, Cr 24. St. 121.

Diagnosis. Female. Carapace short, 1.3 L:W. Pereonite-1 0.7 L:W, pereonites 2-5 subrectangular, pereonites 1-3 weakly wider proximally; pereonites 4-5 margins rounded. Antenna article-4 2.5x article-5. Mandible molar with one process divided into four or five spines. Pereopod-1 merus with one robust spine; carpus with short spines only. Pereopods 4-6 carpus with four spines. 


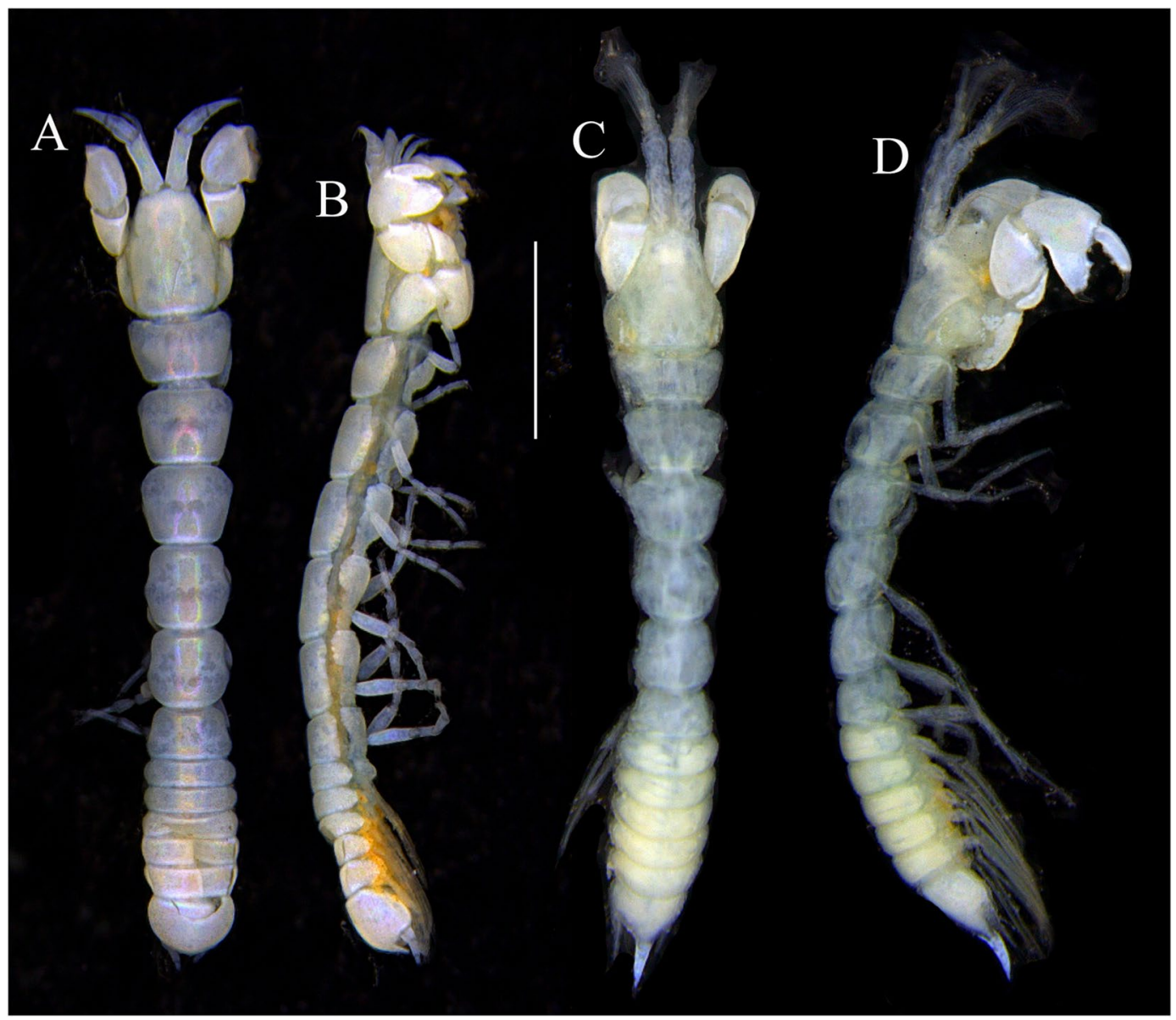

Figure 42. Armatognathia swing sp. nov. Holotype, female (MCZ:IZ:48509). (A) dorsal, (B) lateral, respectively Paratype male (MCZ:IZ:149573) (C) dorsal, (D) lateral. Scale $1 \mathrm{~mm}$.

Etymology. The species collected off the coast of the North America is named after a form of popular music developed in the United States. Noun in apposition.

Description of neuter, length $3.6 \mathrm{~mm}$. Body (Fig. 43A,B) elongate, 9.7 L:W; cephalothorax 1.4 L:W, 1.8x pereonite-1. Pereonites $1-6: 0.7,0.9,0.9,1.0,1.0$ and $0.6 \mathrm{~L}: \mathrm{W}$, respectively. Pleon 0.25 of total body length. All pleonites the same size, $0.3 \mathrm{~L}: \mathrm{W}$. Pleotelson 1.9x pleonite-5. Pleotelson rounded, apex small, directed downward.

Antennule (Fig. 44A) article-1 4.4 L:W, 2.5x article-2, with three middle penicillate setae and one simple and three penicillate distal setae; article-2 1.8 L:W, 2.0x article-3, with one simple and four penicillate setae arranged in transverse row distally; article-3 $0.9 \mathrm{~L}: \mathrm{W}, 0.5 \mathrm{x}$ article- 4 , with long distal seta; article- $4.3 \mathrm{~L}: \mathrm{W}$; article-5 semifused, with article-4, with five long and one short setae, and one aesthetasc distally.

Antenna (Fig. 44B) 0.7 times length of antennule; article-1 fused with body; article-2 $3.2 \mathrm{~L}: \mathrm{W}, 1.3 \mathrm{x}$ article-3, with dorsodistal spine (Fig. 40B'); article-3 1.7 L:W, 0.4x article-4, with dorsodistal seta; article-4 7.9 L:W, 2.4x article-5, with two penicillate midlength setae and two simple and four penicillate setae distally; article-5 4.0 L:W, naked; article- 6 as long as wide, with four long and two short distal setae.

Mouthparts. Labrum (Fig. 44C) distally obtuse with relatively sparse and robust distal setae. Right mandible (Fig. 44E) incisor distally blunt and simple, margin crenulate; molar not observed. Left mandible (Fig. 44D) incisor distally simple; lacinia mobilis well developed, with simple edge; molar distally rounded, with five distal spines. Maxillule endite (Fig. 44G) with nine strong distal spines of various length distally and numerous setae along outer margin; palp (Fig. 44G') with two setae (broken). Maxilla not observed. Labium (Fig. 44H) with two lobes; inner lobe with spines on inner and distal margins; outer lobe smaller than inner lobe, with robust setae on the margin and pointed projection on lateral margin. Maxilliped (Fig. 44I) basis 1.4 L:W, with short distal seta; palp article-1 0.9 L:W, naked; article-2 1.1 L:W, with three serrate inner setae, outer seta not seen; article-3 1.9 L:W, with four inner setae (two robust sparsely serrate, two short serrate); article-4 $2.5 \mathrm{~L}: \mathrm{W}$, with five distal and subdistal inner, sparsely serrate setae, outer seta not seen; maxilliped endites separate, $2.2 \mathrm{~L}: \mathrm{W}$, distally with two round gustatory cusps and two distal setae. Epignath (Fig. 41J) elongate, slender, distally pointed.

Cheliped (Fig. 45A) sclerite large semitriangular; basis 2.6 L:W, subdistal dorsal seta not seen; merus wedge-shape, with ventral seta; carpus $1.2 \mathrm{~L}: \mathrm{W}$, with two ventral setae, one subproximal and one subdistal setae dorsally; chela robust $1.4 \mathrm{x}$ carpus, $1.6 \mathrm{~L}: \mathrm{W}$; propodus (palm) with one seta near dactylus insertion and five setae on inner side (one robust, four short); fixed finger with robust distal spine (unguis) and two ventral setae; cutting margin with triangular tooth proximally, distally well calcified, with three unequal teeth and with three setae; 

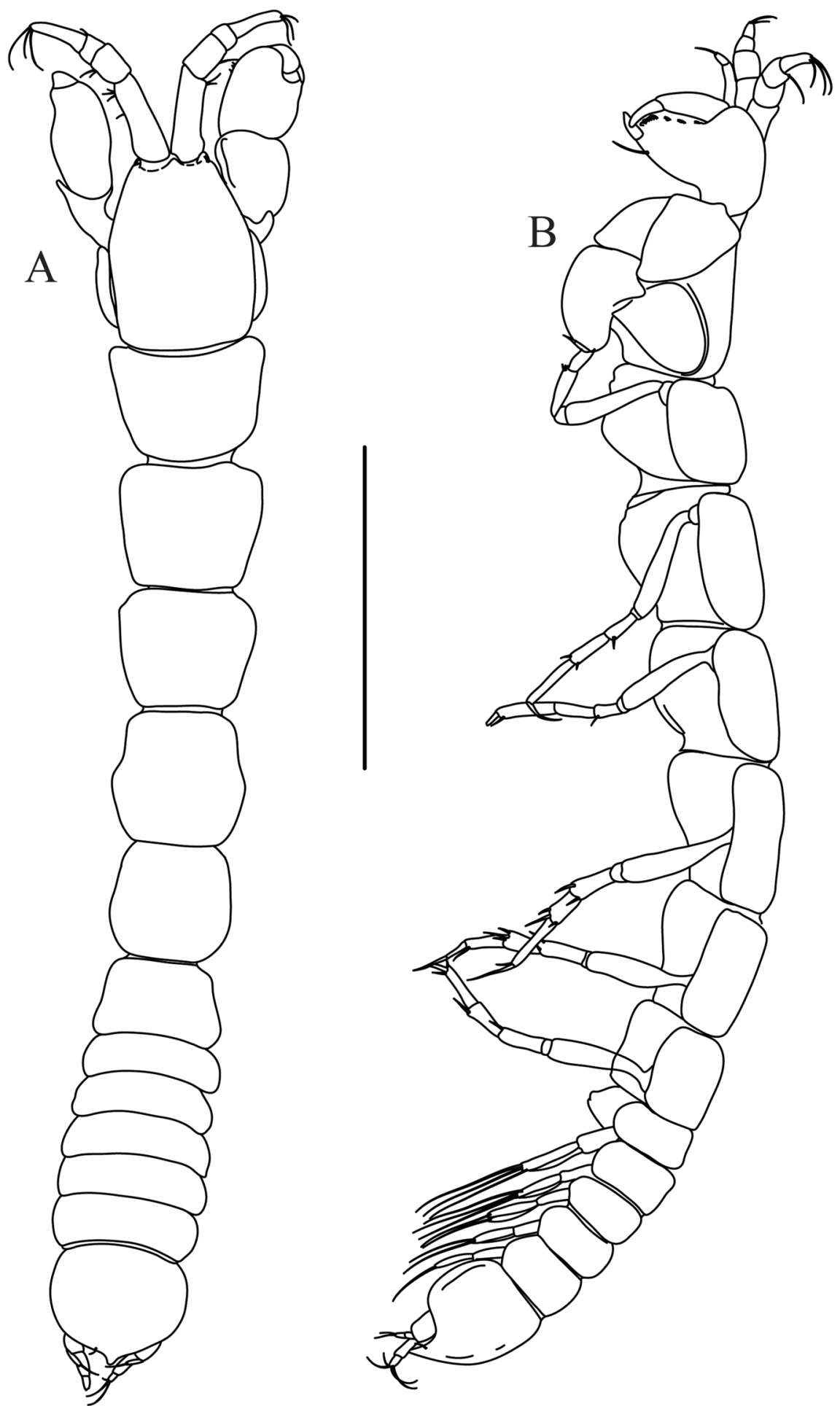

Figure 43. Armatognathia swing sp. nov., Holotype, female (MCZ:IZ:48509) (A) Dorsal. (B) Lateral. Scale 1 mm.

dactylus and fixed finger unifacial; dactylus bent downward, with three robust teeth on cutting margin and subproximal seta on inner side; unguis robust.

Pereopod-1 (Fig. 45B) longer than pereopods 2-3; coxa present, no seta observed; basis $6.5 \mathrm{~L}: \mathrm{W}$, naked; ischium with seta; merus $3.2 \mathrm{~L}: \mathrm{W}, 0.9 \mathrm{x}$ carpus, with serrate distal spine; carpus $3.7 \mathrm{~L}: \mathrm{W}, 0.8 \mathrm{x}$ propodus, with three serrate and one simple distal spines; propodus $6.4 \mathrm{~L}: \mathrm{W}, 2.7 \mathrm{x}$ dactylus, with one ventrodistal and two dorsodistal serrate spine; dactylus 9.0 L:W, $0.7 \mathrm{x}$ unguis, proximal seta not seen; unguis and dactylus about $0.8 \mathrm{x}$ propodus.

Pereopod-2 (Fig. 45C) coxa with one seta; basis 5.4 L:W, with two dorsal penicillate setae; ischium with ventral seta; merus 2.7 L:W, 0.8x carpus, with distal spine; carpus $3.5 \mathrm{~L}: \mathrm{W}, 0.7 \mathrm{x}$ propodus, with four serrate distal spines (three long, one short); propodus 6.2 L:W and 3.0x dactylus, with subdistal ventral serrate spine, fine and serrate 


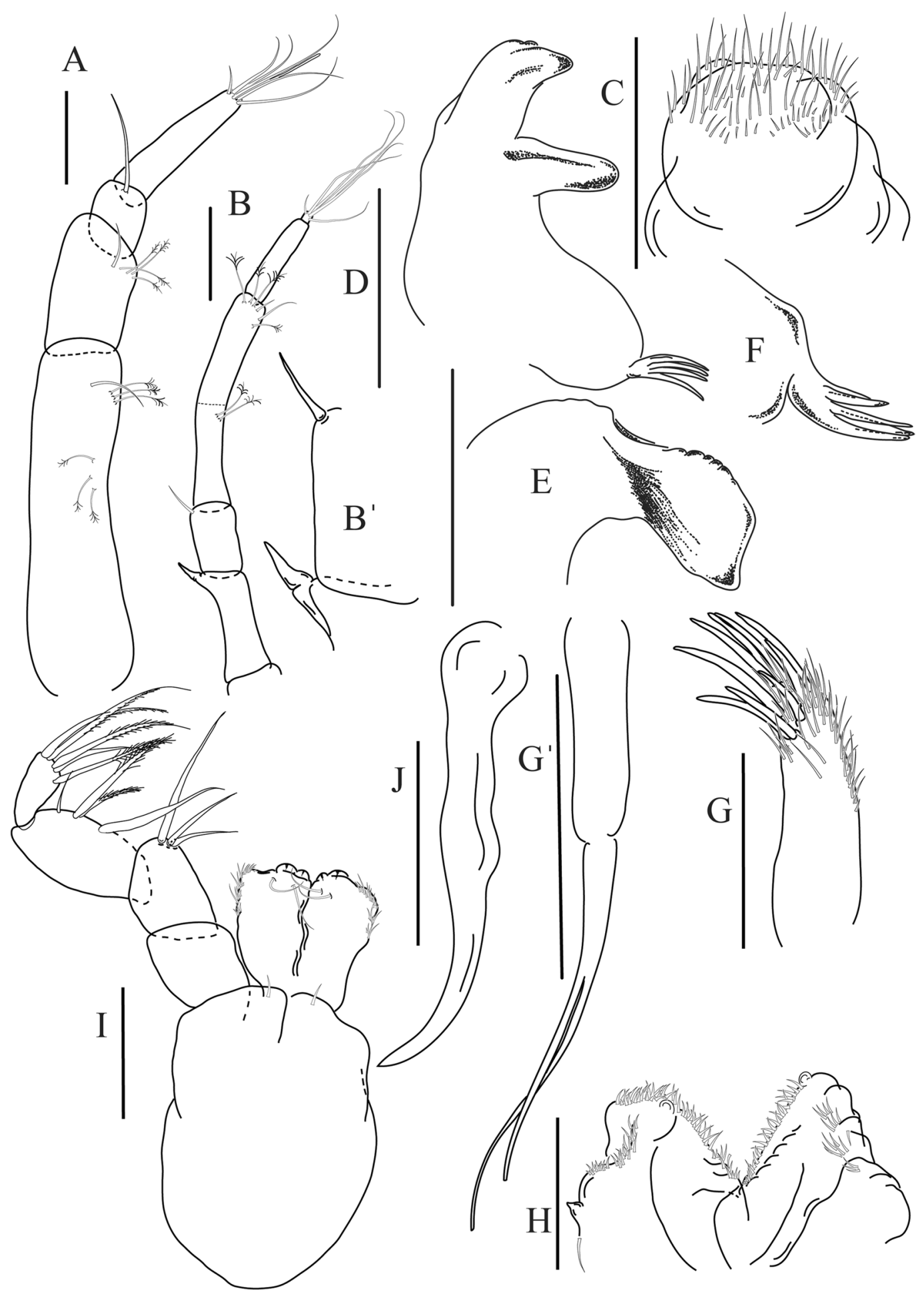

Figure 44. Armatognathia swing sp. nov., paratype, female (MCZ:IZ:149575) (A) Antennule. (B) Antenna. (B') Antennule article 2-3 details. (C) Labrum. (D) Mandible, left. (E) Mandible right, incisor. (F) Mandible right molar, details. (G) Maxillule, endite. (G') Maxillule palp. (H) Labium. (I) Maxilliped. (J) Epignath. Scale $0.1 \mathrm{~mm}$.

spine dorsodistally, numerous microtrichia ventrally; dactylus 7.1 L:W, 0.7x unguis; dactylus and unguis together $0.8 \mathrm{x}$ propodus.

Pereopod-3 (Fig. 45D) similar as pereopod-2, but basis with one penicillate seta.

Pereopod-4 (Fig. 45E) basis 2.9 L:W, with two penicillate setae on ventral margin; ischium with two ventral setae; merus 1.7 L:W, as long as carpus, with two ventrodistal serrate spines; carpus $2.0 \mathrm{~L}: \mathrm{W}, 0.7 \mathrm{x}$ propodus, with four serrate spines and one seta distally; propodus $8.0 \mathrm{~L}: \mathrm{W}$, with two ventrodistal serrate spines and one strongly serrate dorsodistal spine; dactylus $12.5 \mathrm{~L}: \mathrm{W}$; unguis $0.9 \mathrm{x}$ dactylus; together $0.85 \mathrm{x}$ propodus. 


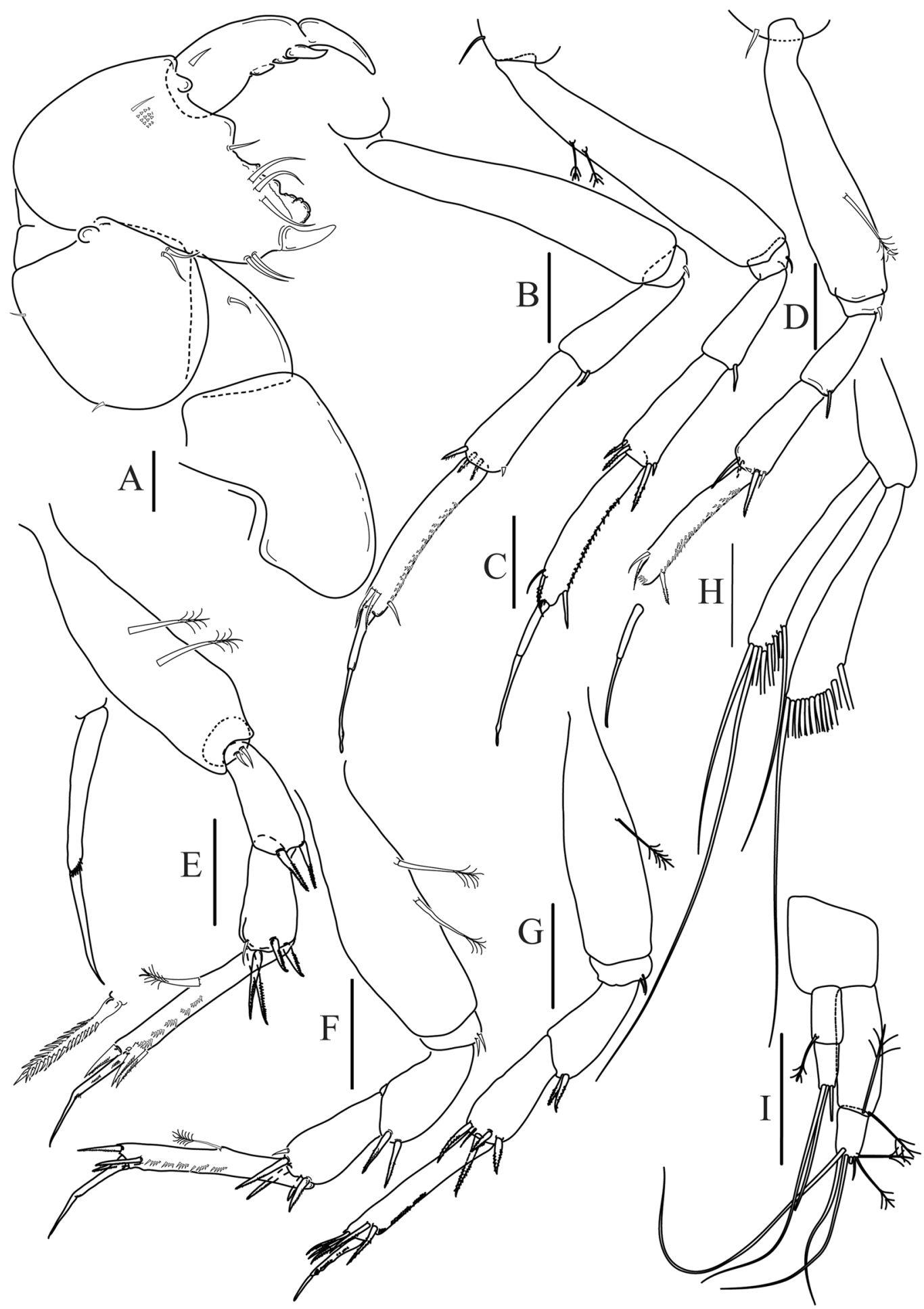

Figure 45. Armatognathia swing sp. nov. Paratype, female (MCZ:IZ:149575) (A) Cheliped. (B-G) Pereopod $1-6$, respectively. (H) Pleopod. (I) Uropod. Scale $0.1 \mathrm{~mm}$.

Pereopod-5 (Fig. 45F) as pereopod-4.

Pereopod-6 (Fig. 45G) similar to pereopod-5, but propodus with three spines dorsodistally.

Uropod (Fig. 45I) basal article 1.4 L:W; exopod with two articles, 0.6x endopod, article-1 1.8 L:W, with distal penicillate seta, article-2 2.6 L:W, with two distal setae; endopod with two articles, article-1 2.0 L:W, 2.5x article-1, with two penicillate distal setae; article-2 1.6 L:W, with five simple and two penicillate setae distally.

Description of adult male, length $3.4 \mathrm{~mm}$. Body (Fig. 46A,B) slender, $8.5 \mathrm{~L}: \mathrm{W}$; cephalothorax as long as wide, $2.5 \mathrm{x}$ pereonite- 1 . Pereonites $1-6: 0.5,0.8,0.7,0.8,0.8$ and $0.5 \mathrm{~L}: \mathrm{W}$, respectively; pereonites $1-3$ wider proximally, pereonites 4 and 5 wider medially, pereonite- 6 wider distally; pleonites lateral side rounded, without 


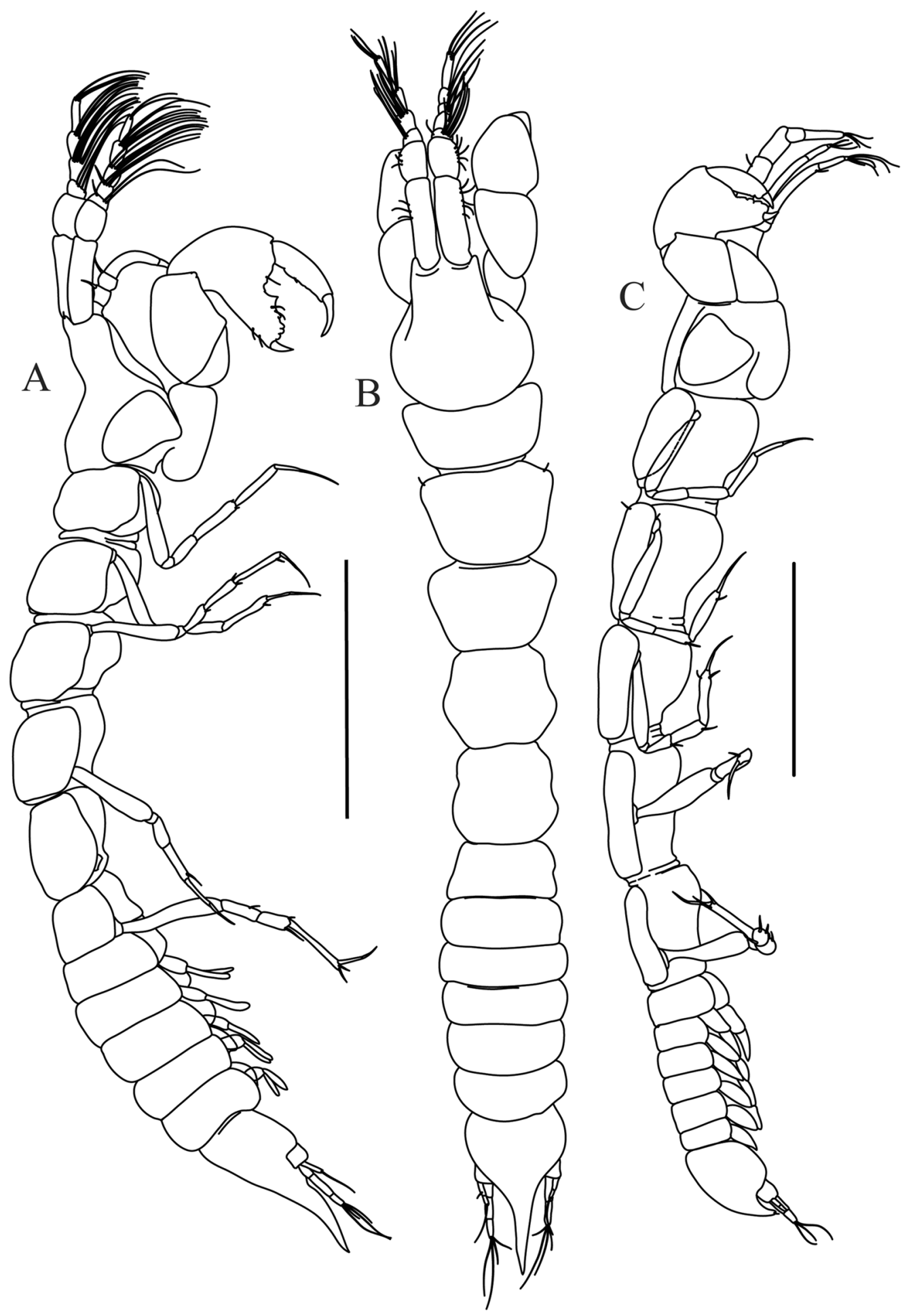

Figure 46. Armatognathia swing sp. nov. Paratype, male (MCZ:IZ:149573) (A) lateral, (B) dorsal. Paratype manca-3 (MCZ:IZ:48541) (C) lateral. Scale $1 \mathrm{~mm}$.

hyposphaenium. Pleon 0,2 of total body length. All pleonites the same size, $0.4 \mathrm{~L}: \mathrm{W}$, with rounded lateral margins. Pleotelson 3.2x pleonite-5, apex 2.0x pleotelson (proximal part).

Antennule (Fig. 47A) article-1 2.3 L:W, 2.1x article-2, with four distal and subdistal penicillate setae; article-2 1.2 L:W, 3.9x article-3, with two penicillate setae distally; article-3 $0.4 \mathrm{~L}: \mathrm{W}$, as long as article-4, with two distal setae; article-4 0.2 L:W, 0.3x article-5, with numerous aesthetascs arranged in transversal row; article-5 0.8 L:W, $0.5 \mathrm{x}$ article- 6 , with numerous long aesthetascs arranged in transversal row; article-6 2.4 L:W. 0.8x article-7, with a few aesthetascs distally; article 7 4.0 L:W, with five setae distally. 


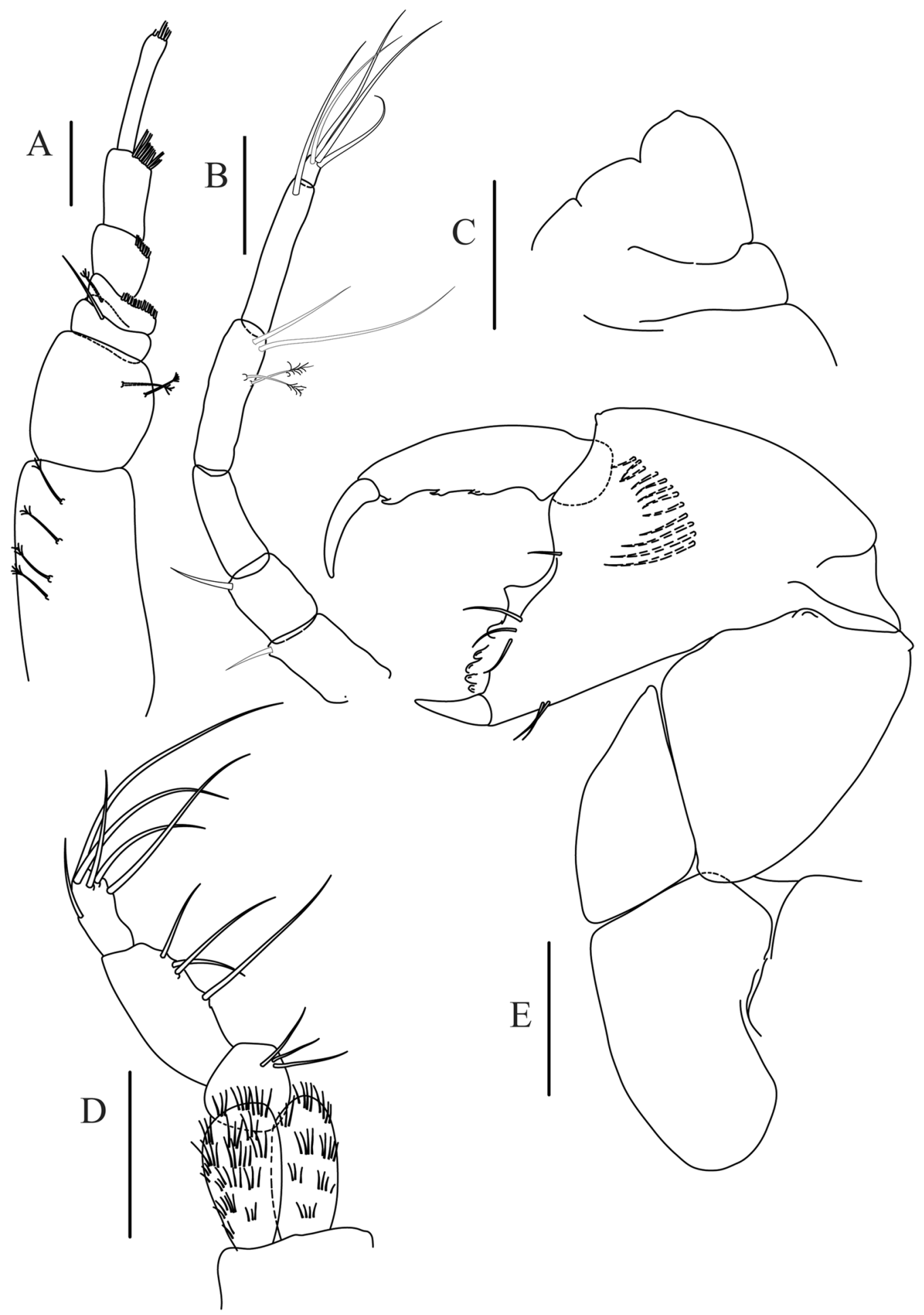

Figure 47. Armatognathia swing sp. nov., paratype, male (MCZ:IZ:149575) (A) Antennule. (B) Antenna. (C) Labrum. (D) Maxilliped. (E) Cheliped. Scale $0.1 \mathrm{~mm}$.

Antenna (Fig. 47B) 0.6 times length of antennule; article-1 fused with body; article-2 1.4 L:W, 0.9x article-3, with distal seta; article-3 1.4 L:W, 0.6x article-4, with distal seta; article-4 3.6 L:W, 0.9x article-5 naked; article-5 7.0 L:W, with two penicillate and two simple setae distally; article-6 $6.0 \mathrm{~L}: \mathrm{W}$, with distal seta; article-7 as long as wide, with at least four distal setae.

Mouthparts. Labrum (Fig. 47C) reduced to naked process, with transversal ridges. Mandible, maxillule, maxilla and labium reduced to small plates (not illustrated). Maxilliped (Fig. 47D) palp article-1 1.2 L:W, naked; article-2 1.3 L:W, with three inner setae; article-3 1.7 L:W, with four long inner setae; article-4 2.9 L:W, with five 


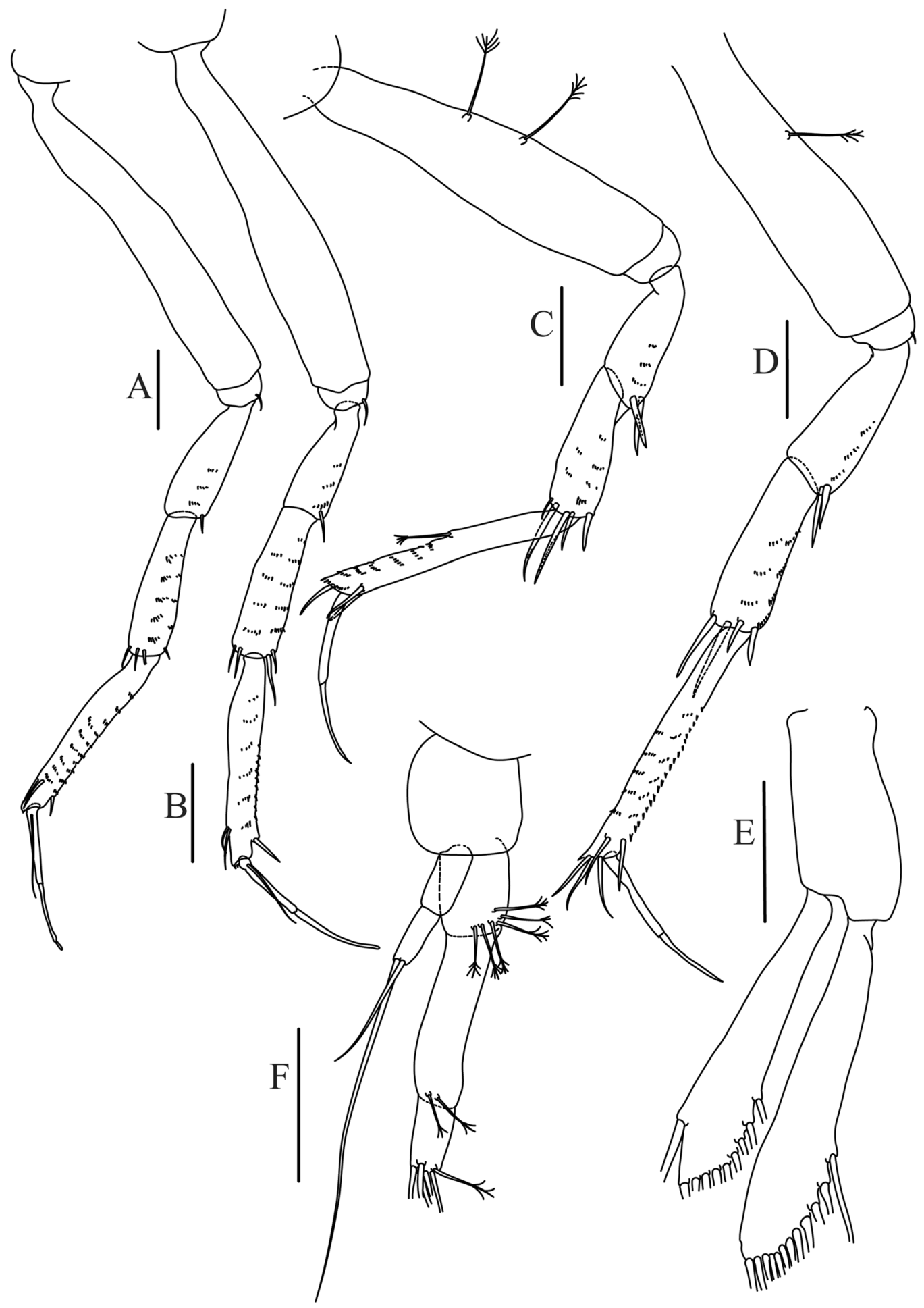

Figure 48. Armatognathia swing sp. nov., paratype, male (MCZ:IZ:149575) (A-D) Pereopod 1, 2, 4 and 6, respectively. (E) Pleopod. (F) Uropod. Scale $0.1 \mathrm{~mm}$.

distal and subdistal inner setae; one outer seta; maxilliped endites separated, narrow with numerous microtrichia. Epignath not seen.

Cheliped (Fig. 47E) basis 2.1 L:W; merus wedge-shape, ventral seta not seen; carpus little wider medially, 1.5 $\mathrm{L}: \mathrm{W}$, setae not seen; chela 1.2x carpus, $1.4 \mathrm{~L}: \mathrm{W}$; propodus (palm) with 12 setae on inner side; fixed finger with calcified inner margin (distally four to five tubercles, proximally triangular tooth), with three setae on cutting edge and two ventral setae; dactylus 5.3 L:W, distally bent downward, with robust unguis.

Pereopod-1 (Fig. 48A) basis 7.2 L:W, naked; ischium with seta; merus $2.6 \mathrm{~L}: \mathrm{W}, 0.7 \mathrm{x}$ carpus, with ventrodistal small spine; carpus $4.2 \mathrm{~L}: \mathrm{W}, 0.8 \mathrm{x}$ propodus, with four small distal spine; propodus $8.0 \mathrm{~L}: \mathrm{W}, 2.5 \mathrm{x}$ dactylus, with 


\begin{tabular}{|c|c|c|c|}
\hline Family & Genera & Species & {$[\%]$} \\
\hline Leptocheliidae & 30 & 126 & 14.1 \\
\hline Typhlotanaidae & 13 & 109 & 12.2 \\
\hline Tanaididae & 19 & 91 & 10.2 \\
\hline Paratanaidae & 10 & 57 & 6.4 \\
\hline Colletteidae & 16 & 56 & 6.3 \\
\hline Akanthophoreidae & 9 & 53 & 5.9 \\
\hline Paratanaoidea incertae sedis & 29 & 52 & 5.8 \\
\hline Pseudotanaidae & 3 & 51 & 5.7 \\
\hline Neotanaidae & 4 & 51 & 5.7 \\
\hline Agathotanaidae & 7 & 51 & 5.7 \\
\hline Tanaellidae & 5 & 49 & 5.5 \\
\hline Leptognathiidae & 1 & 34 & 3.8 \\
\hline Anarthruridae & 16 & 29 & 3.3 \\
\hline Tanaopsidae & 1 & 17 & 1.9 \\
\hline Paranarthrurellidae & 2 & 16 & 1.8 \\
\hline Tanaissuidae & 5 & 12 & 1.3 \\
\hline Nototanaidae & 7 & 12 & 1.3 \\
\hline Cryptocopidae & 6 & 11 & 1.2 \\
\hline Heterotanoididae & 1 & 5 & 0.6 \\
\hline Mirandotanaidae & 3 & 4 & 0.4 \\
\hline Teleotanaidae & 1 & 3 & 0.3 \\
\hline Pseudozeuxidae & 2 & 2 & 0.2 \\
\hline total: & 190 & 891 & \\
\hline
\end{tabular}

Table 6. Diversity and contribution of Paranarthrurellidae fam. nov. to the suborder Tanaidomorpha.

two unequal subdistal spines dorsally and one ventrodistal spine; dactylus $9.0 \mathrm{~L}: \mathrm{W}$, with dorsoproximal seta little longer than dactylus; unguis about as long as dactylus.

Pereopods 2-3 (Fig. 48B) similar to pereopod-1; unguis 1.5x dactylus.

Pereopod-4 (Fig. 48C) basis 5.6 L:W, with two penicillate ventral setae; ischium seta not observed; merus 3.1 $\mathrm{L}: \mathrm{W}$, as long as carpus, with two ventrodistal spines; carpus $3.7 \mathrm{~L}: \mathrm{W}, 0.7 \mathrm{x}$ propodus, with four distal spines (two short and two long) and dorsodistal spine; propodus 9.5 L:W, with two ventrodistal spines and dorsodistal spine; dactylus $10.6 \mathrm{~L}: \mathrm{W}$; unguis $1.1 \mathrm{x}$ dactylus; combined $0.8 \mathrm{x}$ propodus.

Pereopod-5 as pereopod- 4 .

Pereopod-6 (Fig. 48D) similar to pereopod-4, but ischium with one seta and propodus with three dorsodistal spines;

Pleopods 1-5 (Fig. 48E) basal article 2.0 L:W; exopod 0.8x endopod, 5.2 L:W, with nine distal and ventrodistal plumose setae and dorsal long plumose seta; endopod 5.5 L:W, with 11 distal and ventrodistal plumose setae.

Uropod (Fig. 48F) basal article 0.9 L:W; exopod with two articles, 0.3x endopod, article-1 $2.1 \mathrm{~L}: \mathrm{W}$, naked, article-2 2.4 L:W, with two distal setae; endopod with three articles, article-1 $1.2 \mathrm{~L}: \mathrm{W}$, with six penicillate setae; article-2 4.1 L:W, with two penicillate distal setae; article-3 2.0 L:W, with five simple and one penicillate distal setae.

Distribution. The species is known from the Gay Head-Bermuda transect between $4743-4892 \mathrm{~m}$ depth.

Remarks. Armatognathia swing sp. nov. is the second representative of the genus Armatognathia described in the Atlantic Ocean. A third species inhabitant the NE Atlantic in both abyssal Porcupine and Bay of Biscay plains remains undescribed (Bird, pers. comm.). From Armatognathia milonga, the other western Atlantic species (see above), it can be distinguished by the presence of only one small spine on the pereopod-1 merus (small seta and small spine in A. milonga) and shorter carapace that is only 1.3 as long as wide (carapace is $1.7 \mathrm{x} \mathrm{L}: \mathrm{W}$ ). Two other species A. birsteini (type species) and A. shiinoi occur in the Indian Ocean and North Pacific, respectively. The new species can be distinguished by: relatively long antenna article-5, that is 2.5 times as long as article-4 (3.5 times in A. shiinoi) and absence of long distodorsal spine on carpus of pereopod-1 (present on A. shiinoi) and relatively short carapace that is only $1.3 \mathrm{x} \mathrm{L}: \mathrm{W}(2.0 \mathrm{x} \mathrm{L}: \mathrm{W}$ in $A$. birsteini).

\section{Discussion}

Diversity. The new family Paranarthrurellidae is so far represented by 16 nominal species classified to two genera. It is a rather less diverse family that holds $14^{\text {th }}$ place on the list of 21 tanaidomorph families gathering $1.8 \%$ of all tanaidomorph species (Table 6). The two paranarthrurellid genera, Paranarthrurella and Armatognathia, which were removed from Paratanaoidea incertae sedis group, reduced the number of the taxa with uncertain family classification by seven species $(<1 \%)$. Nevertheless, the group Paratanaoidea incertae sedis still contains 52 species and 29 genera (5.8\% and $15.3 \%$, respectively). 


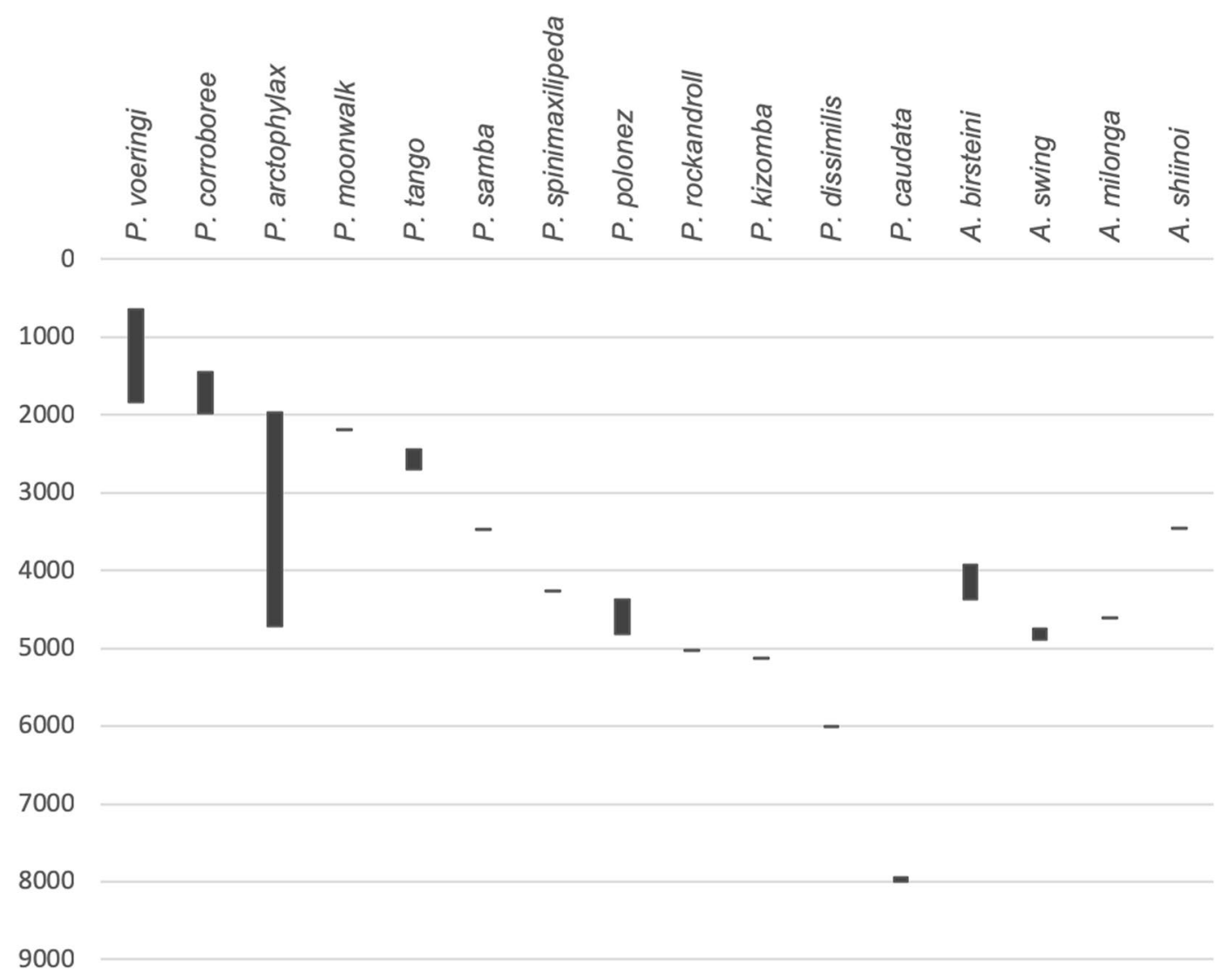

Figure 49. Bathymetric distribution of species for both Paranarthrurella and Armatognathia genera based on current study and literature data.

In case of the species analyzed by us, small but noticeable morphological differences distinguishing each species can be pointed out. In our material, most of them belonging to historical collections ${ }^{2,88}$, we were able to discriminate all the species based only on morphology according to phenotypic condition for species delimitation $^{89}$. In many cases, morphological study is insufficient for identification of various groups of Peracarida crustaceans $^{90-93}$ including tanaids ${ }^{94}$ (Jakiel et al. unpublished data).

The finding of previously undescribed species, as well as considerable cryptic diversity (i.e. high genetic divergence associated with high morphological similarity) is quite common in the vast and under-explored deep-sea ${ }^{95-97}$. Deep-sea peracarids are highly diverse ${ }^{98}$, and, in particular they appear to exhibit high degrees of cryptic and genetic diversity ${ }^{99}$ including amphipods ${ }^{91}$; isopods ${ }^{92,93}$; tanaidaceans ${ }^{94,100}$, Jakiel et al. (submitted). In the material examined herein, high levels of genetic diversity in $18 \mathrm{~S}$ and COI similarly revealed cryptic species whose morphology is indeed different upon thorough re-examination (i.e. Paranarthrurella sp.1, Paranarthrurella sp.2).

Phylogeny. Obtaining reliable quality DNA sequences for the deep-sea small crustaceans is a big challenge. The lack of a reasonable amount of genetic data is a main obstacle for comprehensive phylogenetic analysis that could confidently corroborate the relationship between higher tanaidacean taxa and shed light on origin and radiation place of deep-sea tanaidaceans. So far, the only phylogenetic approach implies, that colonising the deep sea by tanaids might have happened more than once in the Paratanaoidea ${ }^{31}$. Yet, the long branches suggest an ancient diversification of the two main clades: (1) Tanaidae + Neotanaidae and (2) Paratanaoidea with Leptocheliidae and Nototanaidae as ancestors. In our limited molecular approach, all taxa representing here the superfamily Paratanaoidea cluster together in a clade in consistence with the results of Kakui et al. ${ }^{31}$. The Paranarthrurellidae nest within the families showing the most distinctive apomorphic characters, rather than with the Leptocheliidae, a presumed plesiomorphic group.

Distribution and bathymetry. The distribution of all taxa included in the Paranarthrurellidae indicates clearly the cosmopolitan and deep-water nature of the family (Figs 49 and 50). Tanaidacea are an abundant and diverse component of the benthic assemblages in all depths ${ }^{100-102}$ with 15 families of the superfamily Paratanoidea represented in the deep-sea: i.e. Agathotanaidae, Akanthophoreidae, Anarthruridae, Colletteidae, Cryptocopidae, Leptocheliidae, Leptognathiidae, Nototanaidae, Paratanidae, Pseudotanaidae, Pseudozeuxidae, Tanaellidae, Tanaopsidae, Tanaissuidae, and Typhlotanaidae. The Paranarthrurellidae, which is absent on the shelf, would be the sixteenth family within this group. Its occurrence in the deep-sea shows a distributional 


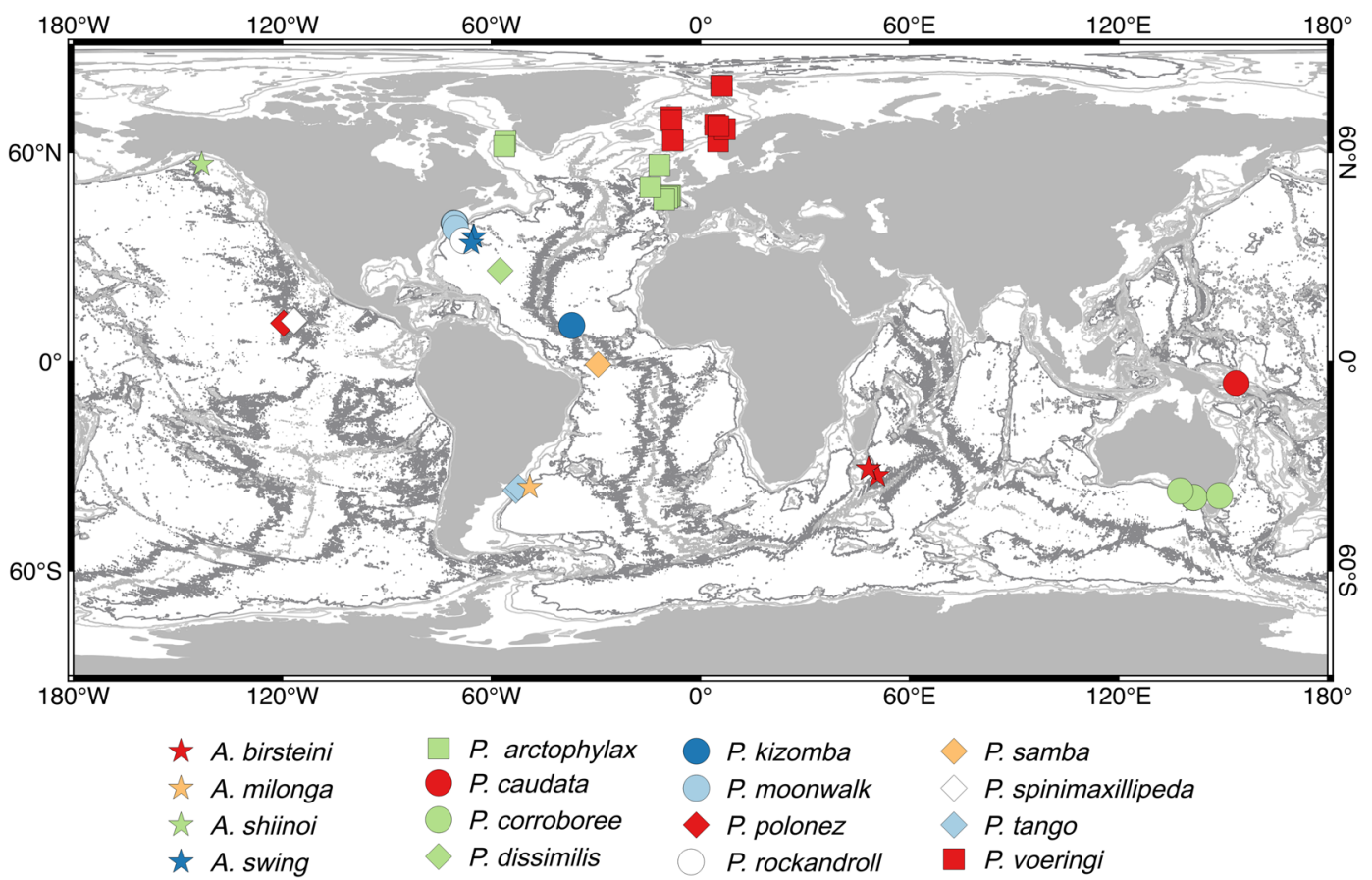

Figure 50. Worldwide distribution of the species of the Paranarthrurellidae fam.nov. based on the current study and literature data ${ }^{2,9,12,16-18,86}$.

range from the bathyal to the hadal depths. The genus Armatognathia appears nearly exclusive to abyssal depths; whereas Paranarthrurella, reported into the hadal, is mainly distributed in the abyss, with an important occurrence in the bathyal (Fig. 49).

Originally described to accommodate one hadal species from the Bougainville Trench, Paranarthrurella holds the shallowest record for the family represented by $P$. voeringi, which is distributed in the upper bathyal of the Subarctic area of the North Atlantic, and P. corroboree occurring on the slope of the SE Australia. The absence of Paranarthrurellidae in shelf depths suggests that this family most probably radiated in the deep-sea, and all Paranarthrurellidae are blind species lacking eyelobes or even remnants thereof. Those lobes, which are occasionally observed in some deep-water representatives e.g. as Protanais birsteini Kudinova-Pasternak, $1970^{103}$ or Bathytanaissus spinulosus Bird and Holdich, $1989^{104}$, advocate for their shallow water ancestry.

Paranarthrurella voeringi shows the most widespread distribution of the species in the family. It has been collected at eight different stations, showing a distribution in the Atlantic Ocean from the $63^{\circ} \mathrm{N}$ to the Arctic waters at the $79^{\circ} \mathrm{N}$ (Table 5, Fig. 39). Furthermore, it exhibits a wide bathymetric range (1195 m). Such a large occurrence for a deep-sea tanaid, has been also noticed in this boreal area for Pseudotanais affinis Hansen, 1887, a putatively cryptic species with a quite similar zoogeography ${ }^{94}$. Within the same area in the Norwegian Basin, two Paranarthrurella species genetically distinguished (sp.1 and sp.2), look morphologically identical to Paranarthrurella voeringi. Both inhabit really cold temperatures (between -0.7 and $-0.8^{\circ} \mathrm{C}$ ) fitting into the range that $P$. voering $i$ has been previously reported (between -0.4 and $\left.-1.4^{\circ} \mathrm{C}\right)^{6,8,61}$ (references Table 5). The co-occurrence of both Paranarthrurella sp.1 and sp.2 at the same station shows how likely other records of $P$. voeringi could also correspond to distinct species from the genetical point of view but showing the same morphological features. Further molecular studies will be necessary to define the name of these species.

In the same way, Paranarthrurella arctophylax was described close to the Norwegian Basin in deeper but warmer area $\left(2.8^{\circ} \mathrm{C}\right)^{105}$, as Hansen noticed when he reported the species from the David Strait between 1.5 and $2.4^{\circ} \mathrm{C}^{8}$ (Table 5). Later on, new records in the northern Bay of Biscay extended its bathymetrical distribution down to the abyssal, holding the widest depth range within the genus $(2750 \mathrm{~m})$; but always in warmer waters than the boreal neighbour $P$. voering $i^{106,107}$. If different water-mass conditions, including temperature, can drive the boundaries between both northern species ( $P$. arctophylax and $P$. voeringi) to not overlap their geographical distribution, more records and genetical evidences would be necessary to prove the occurrence of P. arctophylax as a single species, especially in such a broad distance reported on both sides of the Mid-Atlantic Ridge.

Received: 26 November 2018; Accepted: 31 October 2019; Published online: 10 December 2019

\section{References}

1. Lang, K. Taxonomische und phylogenetische Untersuchungen über die Tanaidaceen 7. Revision der Gattung Strongylura G. 0. Sars, 1882, nebst Beschreibung einer neuen Art dieser Gattung. Ark. för Zool. 23, (403-415 (1971).

2. Kudinova-Pasternak, R. Deep-sea Tanaidacea from the Bougainville Trench of the Pacific. Crustaceana 8, 75-91 (1965). 
3. Kudinova-Pasternak, R. \& Pasternak, F. A. Tanaidacea (Crustacea, Malacostraca) collected by the Soviet Antarctic Expedition during the years 1955-1958 and the correlation of the ranges of the Tanaidacea obtained in the South Ocean and their bathymetrical distribution. Tr. Instituta Okeanol. Akad. Nauk SSSR 115, 108-125 (1981).

4. Kudinova-Pasternak, R. Glubokovodnye tanaidy (Crustacea, Tanaidacea) iz severno-vostocinoi i centralinoi ciastei Indiiskogo Okeana. Zool. Zhurnal 68, 188-192 (1989).

5. Latreille, P. A. Cours d'Entomologie, ou de l'histoire naturelle des Crustacés, des Arachnides, des Myriapodes et des Insects à l'usage des élèves de lécole du Muséum d'Histoire Naturelle (accompagné d’un Atlas). (1831).

6. Sars, G. O. Prodromus descriptionis crustaceorum et pycnogonidarum, quae in expeditione norvegica anno 1876, observavit. Arch. Math. og Naturvidenskab 2, 337-368 (1877).

7. Sars, G. O. Revision af gruppen Chelifera med charakteristik af nye herhen hørende arter og slægter. Arch. Math. og Naturvidenskab 7, 1-54 (1882).

8. Hansen, H. J. Crustacea Malacostraca. The Danish Ingolf-Expedition 3, 1-145 (1913).

9. Lang, K. Bathytanais bathybrothes (Beddard) und Leptognathia dissimilis n. sp. (Tanaidacea). Crustaceana Supplement, 221-236 (1972).

10. Kudinova-Pasternak, R. Deep-sea Tanaidacea, Caribbean Sea, Peuerto Rico Trench. Tr. Instituta Okeanol. Akad. Nauk SSSR 113, 178-197 (1978).

11. Bird, G. J. Tanaidacea of the Atlantic Margin, The afen Surveys of 1996 and 1998. (2001).

12. Norman, A. M. \& Stebbing, T. R. R. V. On the Crustacea Isopoda of the 'Lightning,'Porcupine', and 'Valorous" Expeditions'. Trans. Zool. Soc. London 12, 77-141 (1886).

13. Larsen, K. \& Shimomura, M. Tanaidacea (Crustacea: Peracarida) from Japan. II. Tanaidomorpha from the East China Sea, the West Pacific Ocean and the Nansei Islands. Zootaxa 43, 1-43 (2007).

14. Sieg, J. Tanaidacea (Crustacea) von der Antarktic and Subantarktis. II. Tanaidacea gesammelt von Dr. J. W. Wägele während der Deutschen Antarktis Espedition 1983. Mitteilungen aus dem Zool. Museum Univ. Kiel II, 1-80 (1986).

15. Larsen, K. \& Wilson, G. D. F. Tanaidacean phylogeny, the first step: The superfamily Paratanaidoidea. J. Zool. Syst. Evol. Res. 40, 205-222 (2002).

16. Jóźwiak, P., Stępień, A. \& Błażewicz-Paszkowycz, M. A revision of the genus Paranarthrurella Lang, 1971a (Crustacea: Tanaidacea). Zootaxa 2238, 56-68 (2009).

17. Kudinova-Pasternak, R. Novye Tanaidacea (Crustacea) iz Madagaskarkoi Kothovyny Indiiskogo Okeana). Zool. Zhurnal 66, 28-36 (1987).

18. Larsen, K. \& Araújo-Silva, C. A new genus of Colletteidae (Crustacea: Peracarida: Tanaidacea) from the Pacific with comments on dimorphic males with species specific characters. J. Mar. Biol. Assoc. United Kingdom 94, 969-974 (2014).

19. Bird, G. J. \& Holdich, D. M. Deep-sea Tanaidacea (Crustacea) of the North-east Atlantic: the genus Paranarthrura Hansen. J. Nat. Hist. 23, 137-167 (1989).

20. Sanders, H. L., Hessler, R. R. \& Hampson, G. R. An introduction to the study of deep-sea benthic faunal assemblages along the Gay Head-Bermuda transect. Deep Sea Res. Oceanogr. Abstr. 12, 845-867 (1965).

21. Poore, G. C. B., Just, J. \& Cohen, B. F. Composition and diversity of Crustacea isopoda of the southeastern Australian continental slope. Deep Sea Res. Part I Oceanogr. Res. Pap. 41, 677-693 (1994).

22. Brix, S. et al. PREFACE The IceAGE project-a follow up of BIOICE. Polish Polar Res. 35, 141-150 (2014).

23. Brandt, A. et al. Composition of abyssal macrofauna along the Vema Fracture Zone and the hadal Puerto Rico Trench, northern tropical. Atlantic. Deep Sea Res. Part II Top. Stud. Oceanogr. 148, 35-44 (2018).

24. Martínez Arbizu, P. \& Haeckel, M. EcoResponse Assessing the Ecology, Connectivity and Resilience of Polymetallic Nodule Field Systems. (Helmholtz-Zentrum für Ozeanforschung Kiel/Helmholtz Centre for Ocean Research Kiel, 2015), https://doi.org/10.3289/ GEOMAR_REP_NS 72013.

25. Riehl, T. et al. Field and laboratory methods for DNA studies on deep-sea isopod crustaceans. Polish Polar Res. 35, 203-224 (2014).

26. Johnson, S. B. \& Attramadal, Y. G. Reproductive behaviour and larval development of Tanais cavolinii (Crustacea: Tanaidacea). Mar. Biol. 71, 11-16 (1982).

27. Błażewicz-Paszkowycz, M., Jennings, R. M., Jeskulke, K. \& Brix, S. Discovery of swimming males of Paratanaoidea (Tanaidacea). Polish Polar Res. 35, 415-453 (2014).

28. Coleman, C. O. "Digital inking": how to make perfect line drawings on computers. Org. Divers. Evol. 3, 303-304 (2003),

29. Bird, G. J. \& Bamber, R. N. New littoral, shelf, and bathyal paratanaidae (Crustacea: Peracarida: Tanaidacea) from New Zealand, with descriptions of three new genera. Zootaxa 3676 (2013).

30. Jóźwiak, P., Drumm, D. T., Bird, G. J. \& Błażewicz, M. A new genus of family Akanthophoreidae and new species of genus Tanaidacea: Tanaidomorpha) from the North Atlantic. Mar. Biodivers. 2014 (2018).

31. Kakui, K., Katoh, T., Hiruta, S. F., Kobayashi, N. \& Kajihara, H. Molecular systematics of Tanaidacea (Crustacea: Peracarida) based on $18 \mathrm{~S}$ sequence data, with an amendment of suborder/superfamily-level classification. Zoolog. Sci. 28, 749-757 (2011).

32. Larsen, K. Morphological and molecular investigation of polymorphism and cryptic species in tanaid crustaceans: Implications for tanaid systematics and biodiversity estimates. Zool. J. Linn. Soc. 131, 353-379 (2001).

33. Leray, M. \& Knowlton, N. DNA barcoding and metabarcoding of standardized samples reveal patterns of marine benthic diversity. Proc. Natl. Acad. Sci. 112, 2076-2081 (2015).

34. Araújo-Silva, C. L. \& Larsen, K. Tanaidacea from Brazil. III. New records and description of a new species collected from REVIZEE-NE Program. Nauplius 20, 87-105 (2012).

35. Larsen, K., Nagaoka, R. \& Froufe, E. Tanaidacea (Crustacea) from Macaronesia III. The shallow-water Tanaidomorpha from the Cape Verde archipelago. Zootaxa 3498, 24-44 (2012).

36. Katoh, K. \& Standley, D. M. MAFFT multiple sequence alignment software version 7: Improvements in performance and usability. Mol. Biol. Evol. 30, 772-780 (2013).

37. Talavera, G., Castresana, J., Kjer, K., Page, R. \& Sullivan, J. Improvement of phylogenies after removing divergent and ambiguously aligned blocks from protein sequence alignments. Syst. Biol. 56, 564-577 (2007).

38. Larkin, M. A. et al. Clustal W and Clustal X version 2.0. Bioinformatics 23, 2947-2948 (2007).

39. Tamura, K. et al. MEGA5: Molecular Evolutionary Genetics Analysis using Maximum Likelihood, Evolutionary Distance, and Maximum Parsimony methods. Mol. Biol. Evol. 28, 2731-2739 (2011).

40. Kimura, M. A simple method for estimating evolutionary rates of base substitutions through comparative studies of nucleotide sequences. J. Mol. Evol. 16, 111-20 (1980).

41. Bouckaert, R. et al. BEAST 2: A Software Platform for Bayesian Evolutionary Analysis. PLoS Comput. Biol. 10, e1003537 (2014).

42. Puillandre, N., Lambert, A., Brouillet, S. \& Achaz, G. ABGD, Automatic Barcode Gap Discovery for primary species delimitation. Mol. Ecol. 21, 1864-1877 (2012).

43. Pons, J. et al. Sequence-Based Species Delimitation for the DNA Taxonomy of Undescribed Insects. Syst. Biol. 55, 595-609 (2006).

44. Kapli, P. et al. Multi-rate Poisson Tree Processes for single-locus species delimitation under Maximum Likelihood and Markov Chain Monte Carlo. Bioinformatics 33, btx025 (2017).

45. Kimura, M. Journal of Molecular Evolution A Simple Method for Estimating Evolutionary Rates of Base Substitutions Through Comparative Studies of Nucleotide Sequences. J. Mol. Evol 16 (1980).

46. Clarke, K. R. \& Warwick, R. M. Primer v5: User Manual/Tutorial/. (PRIMER-E Ltd, 2001). 
47. Larsen, K. Revision of the genus Collettea Lang (Crustacea: Tanaidacea). Invertebr. Syst. 14, 681-693 (2000).

48. Bird, G. J. \& Larsen, K. Tanaidacean phylogeny - the second step: the basal paratanaoidean families (Crustacea: Malacostraca). Arthropod Syst. Phylogeny 67, 137-158 (2009).

49. Bird, G. J. A new leptochelioid family, Heterotanoididae (Crustacea: Peracarida: Tanaidacea), and a new species of Heterotanoides from New Zealand. Zootaxa 26, 1-26 (2012).

50. Lang, K. Taxonomische und phylogenetische Untersuchungen über die Tanaidaceen (Crustacea). 8. Die Gattungen Leptochelia Dana, Paratanais Dana, Heterotanais G. O. Sars und Nototanais Richardson, Dazu einige Bemerkungen über die Monokonop. Zool. Scr. 2, 197-229 (1973).

51. Sieg, J. Zum Natürlichen System der Dikonophora Lang (Crustacea, Tanaidacea. J. Zool. Syst. Evol. Res. 14, 177-198 (1976).

52. Sieg, J. Tanaidacea. in Tanaidacea in synopsis and classification of living oranisms 245-249 (McGraw-Hill Book Company, 1982).

53. Błażewicz-Paszkowycz, M. A revision of the family Typhlotanaidae Sieg 1984 (Crustacea: Tanaidacea) with the remarks on the Nototanaidae Sieg, 1976. Zootaxa 1598, 1-141 (2007).

54. Błażewicz-Paszkowycz, M. \& Bamber, R. N. A new genus of a new Austral family of paratanaoid tanaidacean (Crustacea: Peracarida: Tanaidacea), with two new species. Mem. Museum Victoria 66, 5-15 (2009).

55. Bamber, R. N. A new species of Apseudes (Tanaidacea: Apseudomorpha: Apseudidae) from Hong Kong, with observations on Gollumudes mortoni (Bamber, 2001). J. Nat. Hist. 42, 877-884 (2008).

56. Lang, K. Contribution to the systematics and synonymics of the Tanaidacea. Ark. för Zool. 42, (1-14 (1949).

57. Sieg, J. Taxonomische Monographie der Familie Pseudotanaidae (Crustacea, Tanaidacea). Mitteilungen aus dem Museum für Naturkd. Berlin. Zool. Museum und Inst. für Spez. Zool. 53, 3-109 (1977).

58. Jakiel, A., Ste pień, A., Jóźwiak, P., Serigstad, B. \& Błażewicz-Paszkowycz, M. First record of tanaidacea (Crustacea) from a deepsea coral reef in the Gulf of Guinea. Zootaxa 3991, 203-228 (2015).

59. Błażewicz-Paszkowycz, M. \& Bamber, R. N. The shallow-water Tanaidacea (Arthropoda: Malacostraca: Peracarida) of the Bass Strait, Victoria, Australia (other than the Tanaidae). Mem. Museum Victoria 69, 1-235 (2012).

60. Sieg, J. Taxonomische Monographie der Tanaidae Dana 1849 (Crustacea: Tanaidacea). Abhandlungen der Senckenbergischen Naturforschenden Gesellschaft 537, 1-272 (1980).

61. Sars, G. O. Den Norske Nordhavs-Expedition 1876-1878. In Voyage of H.M.S. Challenger. Zoology 6, Zoologi, 1-280, 21 plates (University of Christiania., 1885)

62. Forsstrand, C. Det arktiska hafsområdets djurgeografiska begränsning med ledning af skalkräftornas (Crustacea Malacostraca) utbredning. (Utbredning. Almqvist \& J. Wiksell, 1886).

63. Norman, A. M. British Isopoda Chelifera. Ann. Mag. Nat. Hist. 7, 317-341 (1899).

64. Zirwas, C. Die Isopoden den Nordsee. Wissenschaftliche Meeresuntersuchungen 12, 73-118 (1911).

65. Nierstrasz, H. F. Die Isopoden der Siboga-Expedition. I. Isopoda Chelifera. Siboga Exped. 32a, 1-56 (1913).

66. Stephensen, K. The Tanaidacea and Amphipoda of the Arctic. Fauna Arctica 6, 343-378 (1932).

67. Belyaev, G. M. Donnaya Fauna Najbolshih Glubin (Ultraabissali) Mironogo Okeana. (Nauka, 1966).

68. Kudinova-Pasternak, R. Klescenenosnîie osliki (Tanaidacea) Tihogo Okeana. Biol. Tihogo Okeana 2, 72-74 (1968).

69. Lang, K. Taxonomische, phylogenetische, Untersuchungen, Tanaidaceen. 5. Die Gattung Typhlotanais G.O. Sars, 1882, nebst Beschreibung einer neuen Art dieser Gattung. Dazu eine Berichtigung der Dornenzahl des Enditen der Maxillulae bei T. peculiaris Lang, 196. Ark. för Zool. 23, 266-291 (1968).

70. Lang, K. Taxonomische und phylogenetische Untersuchungen über die Tanadaceen 6. Revision der Gattung Paranarthrura Hansen, 1913, und Aufstellung von zwei neuen Familien, vier neuen Gattungen und zwei neiien Arten. Ark. för Zool. 23, (361-401 (1971).

71. Gardiner, L. F. The systematics, postmarsupial development, and ecology of the deep-sea family Neotanaidae (Crustacea: Tanaidacea). Smithson. Contrib. to Zool, 1-265, https://doi.org/10.5479/si.00810282.170 (1975).

72. Sieg, J. Evolution of Tanaidacea. in Crustacean phylogeny (ed. Schram, F. R.) 229-256 (A.A. Balkema, 1983).

73. Sieg, J. Distribution of the Tanaidacea: Synopsis of the known data and suggestions on possible distribution patterns. in Crustacean biogeography (eds Gore, R. T. \& Heck Kenneth L) 165-194 (A.A.Balkema, 1986).

74. Sieg, J. Ein Beitrag zum Natûrlichen System der Dikonophora Lang. Diss. Christ. Kiel, 1-298 (1973).

75. Sieg, J. Aufteilung der Anarthruridae Lang in zwei Unterfamilien sowie neubeschreibung von Tanais willemoesi Studer als TypusArt der Gattung Langitanais Sieg (Tanaidacea). Crustaceana 35, 119-133 (1978).

76. Bird, G. J. Families Anarthruridae Lang, 1971, Colletteidae Larsen \& Wilson, 2002, and Leptognathiidae Sieg, 1976. Zootaxa 1599, 61-85 (2007).

77. Larsen, K., Gutu, M. \& Sieg, J. Order Tanaidacea Dana, 1849. In The Crustacea. Revised and updated, as well as extended from the Traite de Zoologie (ed. von Klein, V. J. C.) 249-329 (Brill, 2015).

78. Wi, J. H., Suh, H. L. \& Kim, D. Three new species of the deep-sea genus Collettea Lang, 1973 (Tanaidacea; Colletteidae) in the eastern central Pacific. J. Crustac. Biol. 35, 714-727 (2015).

79. Morales Núñez, A., Larsen, K. \& Cooke, W. Oahutanais makalii, a new genus and species of colletteid tanaidacean (Crustacea, Peracarida) from shelf-waters off Hawaii, with a taxonomic key. Zoosystematics Evol. 92, 1-12 (2016).

80. Bird, G. J. Tanaidacea (Crustacea: Peracarida) of the North-east Atlantic: The genera Leptognathioides and Portaratrum of the 'Atlantic Margin' J. Nat. Hist. 48, 1771-1815 (2014).

81. Holdich, D. M. \& Bird, G. J. A preliminary report on 'Dikonophoran' tanaids (Crustacea). Peuplements Profond. du Golf. Gascogne, Campagnes BIOGAS, 441-448 (1985).

82. Bamber, R. N. Suborders Apseudomorpha Sieg, 1980 and Neotanaidomorpha Sieg, 1980*. Zootaxa 1599, 13-40 (2007).

83. Błażewicz-Paszkowycz, M. \& Bamber, R. N. Tanaidomorph tanaidacea (crustacea: Peracarida) from mud-volcano and seep sites on the Norwegian Margin. Zootaxa (2011).

84. Gutu, M. \& Sieg, J. Ordre des Tanaidaces. in Traite de Zoologie, Crustaces Pericarides (ed. Forest, J.) 353-389 (Memoires de l'Institut Oceanographique, 1999).

85. Larsen, K. Deep-Sea Tanaidacea (Peracarida) from the Gulf of Mexico. (Brill, 2005).

86. Kudinova-Pasternak, R. Tanaidacea (Crustacea, Malacostraca) collected on the R/V Vitjas in regions of the Aleutian Trench and Alaska. Tr. Instituta Okeanol. Akad. Nauk SSSR 91, 141-168 (1973).

87. Jóźwiak, P. \& Błażewicz-Paszkowycz, M. New records of the family Agathotanaidae (Crustacea: Tanaidacea) in the Antarctic, with remarks on Arthrura monacantha (Vanhöffen, 1914). Zootaxa 2785, 32-52 (2011).

88. Hessler, R. R. \& Sanders, H. L. Faunal diversity in the deep-sea. Deep. Res. 14, 65-78 (1967)

89. Hausdorf, B. Progress toward a general species concept. Evolution (N. Y). 65, 923-931 (2011)

90. Bober, S., Riehl, T., Henne, S. \& Brandt, A. New Macrostylidae (Isopoda) from the Northwest Pacific Basin described by means of integrative taxonomy with reference to geographical barriers in the abyss. Zool. J. Linn. Soc. 182, 549-603 (2018).

91. Havermans, C. et al. Genetic and morphological divergences in the cosmopolitan deep-sea amphipod Eurythenes gryllus reveal a diverse abyss and a bipolar species. PLoS One 8, e74218 (2013).

92. Kaiser, S., Brix, S., Kihara, T. C., Janssen, A. \& Jennings, R. M. Integrative species delimitation in the deep-sea genus Thaumastosoma Hessler, 1970 (Isopoda, Asellota, Nannoniscidae) reveals a new genus and species from the Atlantic and central Pacific abyss. Deep. Res. Part II Top. Stud. Oceanogr. 148, 151-179 (2018). 
93. Jennings, R. M., Brix, S., Bober, S., Svavarsson, J. \& Driskell, A. More diverse than expected: distributional patterns of Oecidiobranchus Hessler, 1970 (Isopoda, Asellota) on the Greenland-Iceland-Faeroe Ridge based on molecular markers. Mar. Biodivers. 48, 845-857 (2018).

94. Jakiel, A., Stępień, A. \& Błażewicz, M. A tip of the iceberg-Pseudotanaidae (Tanaidacea) diversity in the North Atlantic. Mar. Biodivers. 48, 859-895 (2018).

95. Etter, R. J., Rex, M. A., Chase, M. C. \& Quattro, J. M. A genetic dimension to deep-sea biodiversity. Deep. Res. I 46, 1095-1099 (1999).

96. Gubili, C. et al. Species diversity in the cryptic abyssal holothurian Psychropotes longicauda (Echinodermata). Deep. Res. Part II Top. Stud. Oceanogr. 137, 288-296 (2017).

97. Baco, A. R. et al. A synthesis of genetic connectivity in deep-sea fauna and implications for marine reserve design. Mol. Ecol. 25, 3276-3298 (2016).

98. Frutos, I., Brandt, A. \& Sorbe, J. C. Suprabenthic communities: the forgotten biodiversity. in Suprabenthic communities: the forgotten biodiversity (eds Rossi, S., Bramanti, L., Gori, A. \& Orejas Saco del Valle, C.) 475-503 (Springer International Publishing, 2017).

99. Brandt, A. et al. Are there widespread peracarid species in the deep sea (Crustacea: Malacostraca)? Polish Polar Res. 33, 139-162 (2012).

100. Błażewicz-Paszkowycz, M., Bamber, R. N. \& Anderson, G. Diversity of Tanaidacea (Crustacea: Peracarida) in the World’s Oceans - How far have we come? PLoS One 7, e33068 (2012).

101. Błażewicz-Paszkowycz, M. The biogeographic Atlas of the Southern Ocean. In Biogeographic Atlas of the Souther Ocean (ed. De Broyer C., Koubbi P., Griffiths H. J., Raymond B., Udekem d'Acoz C. d', et al. (eds)) 173-180 (Census of Antarctic Marine Life SCAR-Marine Biodiversity Information Network, 2014).

102. Błażewicz-Paszkowycz, M., Pabis, K. \& Jóźwiak, P. Tanaidacean fauna of the Kuril-Kamchatka Trench and adjacent abyssal plain - abundance, diversity and rare species. Deep. Res. Part II Top. Stud. Oceanogr. 111, 325-332 (2015).

103. Błażewicz-Paszkowycz, M., Kobyłecka, E. \& Jennings, R. N. Redescription of wood-associated tanaidacean Protanais birsteini (Tanaidacea) and its relationship within the Tanaididae. Deep Sea Res. Part II Top. Stud. Oceanogr. 111,333-342 (2015).

104. Bird, G. J. \& Holdich, D. M. Recolonisation of artificial sediments in the deep Bay of Biscay by tanaidaceans (crustacea: Peracarida), with a description of a new species of Pseudotanais. J. Mar. Biol. Assoc. United Kingdom 69, 307-317 (1989).

105. Carpenter, J., Jeffreys, G. \& Thomson, W. Preliminary Report of the Scientific Exploration of the Deep Sea in H.M. SurveyingVessel 'Porcupine', during the Summer of 1869. Proc. R. Soc. London 18, 397-492.

106. Bird, G. J. \& Holdich, D. M. New deep-sea Leptognathiid Tanaids (Crustacea, Tanaidacea) from the North-east Atlantic, 285-315 (1985).

107. Vangrieshem, A. Hydrobiologie et circulation profonde. in Peuplements profonds du Golfe de Gascogne. Campagnes Biogas. IFREMER (eds Laubier, L. \& Monniot, C.) 43-70 (1985).

108. Knudsen M. Hydrography. The Danish Ingolf-Expedition, vol 1, part I. 2. 23-161 pp + 34 plates (1899).

109. Boeggild, O. B. The deposit of the sea-bottom. The Danish Ingolf-Expedition, vol 1, part II. 3. 1-89 pp +7 charts (1900).

110. Auffret, G. A. Environnement morphologique et sédimentologique. In: Peuplements profonds du Golfe de Gascogne. Campagnes Biogas. IFREMER (eds Laubier, L., \& Monniot, C.) 71-99 (1985).

111. Budéus, G. Physical oceanography during POLARSTERN cruise ARK-XX/1. Alfred Wegener Institute, Helmholtz Center for Polar and Marine Research, Bremerhaven, PANGAEA, https://doi.org/10.1594/PANGAEA.772927 (2011)

112. Beszczynska-Möller, A. \& Wisotzki, A. Physical oceanography during POLARSTERN cruise ARK-XXIII/2. Alfred Wegener Institute, Helmholtz Center for Polar and Marine Research, Bremerhaven, PANGAEA, https://doi.org/10.1594/PANGAEA.733424 (2010)

113. Brix, S. et al. Cruise Report M85/3 IceAGE1 2011 with RV Meteor. Technical Report. 41 pp. (2012).

114. Brix, S. et al. Distributional patterns of isopods (Crustacea) in Icelandic and adjacent waters. Marine Biodiversity 48, 783-811 (2018).

\section{Acknowledgements}

The authors thank the crew of the RVs Meteor and Sonne and all participants to the oceanographic cruises for their help during sampling at sea. We would also like to thank to Adam Baldinger for the loans from Museum of Comparative Zoology, Harvard University and to Jo Taylor and Melanie McKenzie for the loans the collection of Melbourne Museum. Loan of the type species Paranarthrurella caudata from the Museum of Moscow thanks to Dr Dimitry Y. Sorokin. We also thank Dr. Graham Bird, who also kindly provided us the BIOICE specimens for the redescription of Paranarthurella arctophylax, and other anonymous reviewer for their comments that improved this manuscript. This study was supported by Polish National Science Centre grant 2016/21/B/ NZ8/02495. The Vema-TRANSIT project was undertaken with financial support of the PTJ (German Ministry for Science and Education), grant 03G0227A to Prof. Angelika Brandt; I. Frutos received a Postdoctoral fellowship from the Bauer Foundation (Germany).

\section{Author contributions}

This study was designed by M.B. All authors wrote in manuscript and I.F. also edited. Laboratory work was coordinated by M.B. and conducted by all authors. R.J. carried out the genetic analyses, M.B. and P.J. identified material and I.F. undertook the geographical studies. M.B. and I.F. discussed results, P.J. prepared electronic version of the figures and photographs and M.S. carried out the confocal microscopy imaging. M.B. collected IceAGE and JPIO material and I.F. Vema-TRANSIT material.

\section{Competing interests}

The authors declare no competing interests.

\section{Additional information}

Correspondence and requests for materials should be addressed to I.F.

Reprints and permissions information is available at www.nature.com/reprints.

Publisher's note Springer Nature remains neutral with regard to jurisdictional claims in published maps and institutional affiliations. 
(c) (i) Open Access This article is licensed under a Creative Commons Attribution 4.0 International License, which permits use, sharing, adaptation, distribution and reproduction in any medium or format, as long as you give appropriate credit to the original author(s) and the source, provide a link to the Creative Commons license, and indicate if changes were made. The images or other third party material in this article are included in the article's Creative Commons license, unless indicated otherwise in a credit line to the material. If material is not included in the article's Creative Commons license and your intended use is not permitted by statutory regulation or exceeds the permitted use, you will need to obtain permission directly from the copyright holder. To view a copy of this license, visit http://creativecommons.org/licenses/by/4.0/.

(c) The Author(s) 2019 